\title{
INDICADORES DE CONSUMO DE ENERGIA ELÉTRICA COMO FERRAMENTAS DE APOIO À GESTÃO: \\ CLASSIFICAÇÃO POR PRIORIDADES DE ATUAÇÃO NA UNIVERSIDADE DE SÃO PAULO
}

Dissertação apresentada à Escola Politécnica da Universidade de São Paulo para obtenção do título de Mestre em Engenharia.

Área de Concentração:

Sistemas de Potência

Orientador:

Prof. Dr. Marco Antonio Saidel 
Este exemplar foi revisado e alterado em relação à versão original, sob responsabilidade única do autor e com a anuência de seu orientador.

São Paulo, 09 de Outubro de 2007.

Autor: Clayton Morales

Orientador: Marco Antonio Saidel

\section{FICHA CATALOGRÁFICA}

Morales, Clayton

Indicadores de consumo de energia elétrica como ferramenta de apoio à gestão: Classificação por prioridades de atuação na Universidade de São Paulo / C. Morales. -- São Paulo, 2007. $101 \mathrm{p}$.

Dissertação (Mestrado) - Escola Politécnica da Universidade de São Paulo. Departamento de Engenharia de Energia e Automação Elétricas.

1.Consumo de energia elétrica (Indicadores; Gerenciamento) I.Universidade de São Paulo. Escola Politécnica. Departamento de Engenharia de Energia e Automação Elétricas II.t. 


\section{CLAYTON MORALES}

\section{INDICADORES DE CONSUMO DE ENERGIA ELÉTRICA COMO FERRAMENTAS DE APOIO À GESTÃO: CLASSIFICAÇÃO POR PRIORIDADES DE ATUAÇÃO NA UNIVERSIDADE DE SÃO PAULO}

Dissertação apresentada à Escola Politécnica da Universidade de São Paulo para obtenção do título de Mestre em Engenharia. 


\section{DEDICATÓRIA}

Aos meus Pais, Bernardo e Albeli pelo Amor, apoio e incentivo durante toda a vida. Aos meus amigos que sempre participaram de minha formação pessoal. À Adriana, minha amiga, companheira e amante pela compreensão e dedicação. 


\section{AGRADECIMENTOS}

Agradeço a Deus e a seus anjos pela vida e as oportunidades dadas.

Aos meus pais pelo grande amor dedicado, apoio e incentivo durante toda minha vida.

Aos meus amigos que sempre participaram direta ou indiretamente em minha formação pessoal, ajudando a me tornar uma pessoa feliz.

À Adriana, minha grande amiga, companheira e amante pela dedicação desde que estamos juntos, pelo amor e compreensão nas fases mais complicadas.

À CAPES, Coordenação de Aperfeiçoamento de Pessoal de Nível Superior, pela bolsa de mestrado concedida.

Ao Prof. Saidel pela orientação durante este trabalho e pela confiança e oportunidade em uma fase muito importante de minha vida.

Aos amigos do PEA pelo companheirismo, discussões e pelas conversas de "boteco".

Aos amigos do GEPEA pela amizade e auxílio no desenvolvimento deste trabalho.

Enfim, agradeço a todos que participaram direta e indiretamente na preparação desta dissertação. 
RESUMO

MORALES, C. Indicadores de consumo de energia elétrica como ferramentas de apoio à gestão: A classificação por prioridades de atuação na Universidade de São Paulo. 2007. 100 p. Dissertação de Mestrado - Escola Politécnica, Universidade de São Paulo, São Paulo, 2007.

Este trabalho utiliza indicadores de energia para caracterizar unidades consumidoras da Universidade de São Paulo pelo comportamento no uso da eletricidade e estabelecer prioridades de atuação para gestão dos recursos e ações de eficiência energética. Os indicadores foram aplicados na base de dados de consumo de energia extraídos da ferramenta de gestão da USP, o SISGEN, juntamente com as informações físicas, de ocupação, principais usos finais e custos de utilização da energia, em 48 unidades da Cidade Universitária Armando de Sales Oliveira. Os resultados foram utilizados para elaborar listas de prioridades de atuação para cada um dos indicadores e, a partir da análise desses resultados foi possível identificar tendências e semelhanças de comportamento no uso da energia elétrica no campus. Visando auxiliar na análise dos resultados, utilizou-se de uma classificação prévia por especialidades de ensino ou atividades desenvolvidas e, dois períodos distintos, cujo comportamento tende a sofrer alterações, ou seja, letivo e férias escolares. De posse de todas as informações e resultados elaborou-se uma classificação final no intuito de auxiliar os gestores na priorização das ações de gestão dos recursos e eficiência energética.

Palavras-chave: Gestão de Energia, Eficiência Energética, Indicadores de Consumo de Energia, Comportamento no Uso da Energia, Ferramentas de Gestão. 


\begin{abstract}
MORALES, C. Electric Energy consumption indicators as a management support tool: Action priority classification at Universidade de São Paulo. 2007. 100 p. Dissertação de Mestrado - Escola Politécnica, Universidade de São Paulo, São Paulo, 2007.
\end{abstract}

The work here presented uses indicators to classify energy consumption units at Universidade de São Paulo by consumption behavior and also to prioritize actions on resources management and establish energy efficiency actions. Such indicators have been applied to the energy consumption data base from the USP management tool, called SISGEN, together with current information on: occupation; main final uses and energy use costs gathered from 48 consumption units at Cidade Universitária Armando de Sales Oliveira. The results have been used to elaborate action priority lists to each one of the mentioned indicators. Besides, based on the analysis of these results, it has been possible to identify tendencies and similarities on the electric energy use at the campus. In order to support the results analysis, units have been previously classified in education specialties or activity developed, and also in two different periods of the year, when their behavior tend to vary: school vacation and teaching period. With all results and necessary information in hands a final classification has been established which goal was to support managers on prioritizing manage resources and establish energy efficiency actions.

Key-words: Electric Energy Management, Energy Efficiency, Energy Consumption Indicators, Behavior in the use of the Energy electric energy, Tools of Management. 


\section{LISTA DE FIGURAS}

FIGURA 1: FLUXOGRAMA DE APLICAÇÃO DA METODOLOGIA PROPOSTA ...................................... 26

FIGURA 2: PARTICIPAÇÃO DOS CAMPI NO DISPÊNDIO COM ELETRICIDADE, 2004 (SAIDEL, 2005) . 43

FIGURA 3 - TELA DE INCLUSÃO DAS INFORMAÇÕES DAS FATURAS DE ENERGIA (A4 -

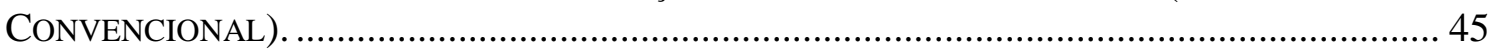

FIGURA 4 - GRÁFICO DA CURVA DE CARGA DIÁRIA DE UMA UNIDADE CONSUMIDORA. ................ 47

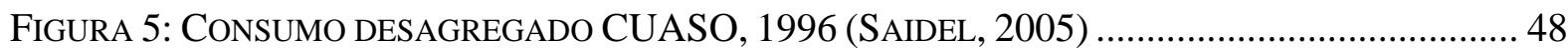

FiguRA 6: TECNOLOGIA DE ILUMINAÇÃo UTILIZADA (SAIDEL, 2005) …....................................... 48

FIGURA 7: ESTRATIFICAÇÃO DA TECNOLOGIA DE ILUMINAÇÃO FLUORESCENTE (SAIDEL, 2005).. 49

FIGURA 8: CONSUMO X TEMPERATURA - FEVEREIRO 2004 (SAIDEL ET. AL., 2006)................... 51

FiguRA 9: EVOLUÇÃO DE CONSUMO CUASO - JAN/05 A Nov/06 ….......................................... 54

Figura 10: CuRva de CARGa MÉdia MENSAL - OUtubro 2006 .............................................. 57

FiguRA 11: CONSUMO TOTAL X MONITORAMENTO SISGEN - OUTUBRO 2006 ......................... 57

FIGURA 12: CURVA DE CARGA MÉDIA - DiAs ÚTEIS - OUTUBRo 2006 ....................................... 58

Figura 13: CuRVA DE CARgA MÉdiA - DiAs NÃo ÚtEIS - OUTUBRo 2006................................. 58 


\section{LISTA DE TABELAS}

TABela 1: Potencial DE CONSERVAÇÃo de ENERgIA ELÉTRICA EM EquiPAMENTOS DE ESCRITÓRIO (ALVAREZ,1998)

TABELA 2: ECONOMIA DE ENERGIA EM COMPUTADORES COM O ENERGY SAVER ACIONADO (SANTOS, 2004) 38

TABELA 3: DiSTRIBUIÇÃo DE FATURAS POR CIDADE/CAMPUS (SAIDEL, 2005) ................................ 42

TABELA 4: MONITORAMENTO do SISGEN NA CUASO - NOVEMBRo 2006. .............................. 52

TABELA 5: UNIDADES MONITORADAS CONSIDERADAS NO ESTUDO DE CASO................................ 53

TABELA 6: CLASSIFICAÇÃO PRÉVIA POR ESPECIALIDADE DE ENSINO OU ATIVIDADE ..................... 56

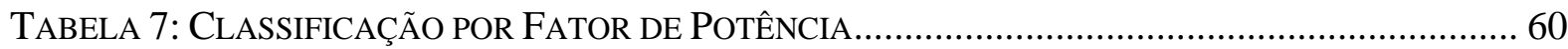

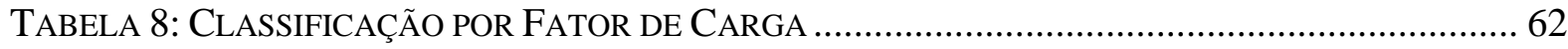

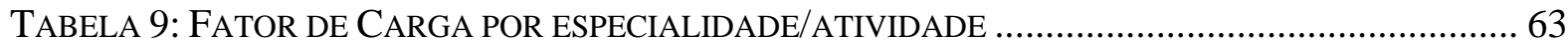

TABELA 10: CLASSIFICAÇÃO POR HORÁRIOS DE UTILIZAÇÃO ........................................................ 65

TABELA 11: HORÁRIOS DE UTILIZAÇÃO POR ESPECIALIDADE/ATIVIDADE .................................... 66

TABELA 12: CLASSIFICAÇÃO POR USUÁRIOS DA ENERGIA - GERAL …........................................... 67

TABELA 13: CLASSIFICAÇÃO POR USUÁRIOS DA ENERGIA - ESPECIALIDADE/ATIVIDADE ............... 68

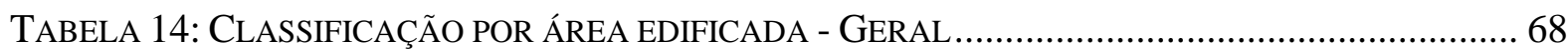

TABELA 15: CLASSIFICAÇÃO POR ÁREA EDIFICADA - ESPECIALIDADE/ATIVIDADE .......................... 69

TABELA 16: CLASSIFICAÇÃO POR USO FINAL: AR CONDICIONADO E REFRIGERAÇÃO................... 71

TABELA 17: ClassifiCAÇão POR Uso FINAL: AR CONDICIONADO E REFRIGERAÇÃO - ÁREA

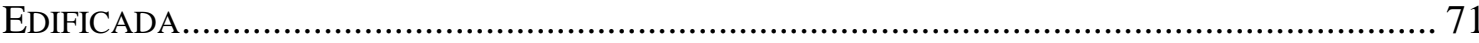

TABELA 18: ClASSIFICAÇÃO POR USO FINAL: AR CONDICIONADO E REFRIGERAÇÃO - USUÁRIOS

TABELA 19: CLASSIFICAÇÃO POR USO FINAL: ILUMINAÇÃO ........................................................ 72

TABELA 20: CLASSIFICAÇÃO POR USO FINAL: EQUIPAMENTOS DE INFORMÁTICA - USUÁRIOS

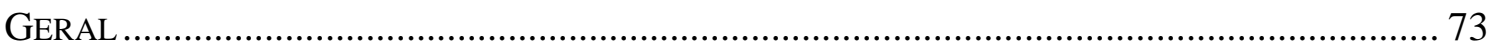


TABELA 21: CLASSIFICAÇÃO POR USO FINAL: EQUIPAMENTOS DE INFORMÁTICA - USUÁRIOS POR ESPECIALIDADE/ATIVIDADE

TABELA 22: INDICADORES FINANCEIROS: CUSTOS ENERGIA ELÉTRICA NA CUASO - USUÁRIOS E ÁREA EDIFICADA.

TABELA 23: INDICADORES FINANCEIROS: CUSTOS PERCENTUAIS POR UNIDADE - USUÁRIOS POR

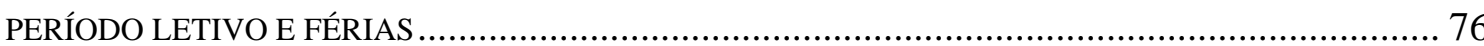

TABELA 24: INDICADORES FINANCEIROS: CUSTOS PERCENTUAIS POR UNIDADE - ÁREA EDIFICADA POR PERÍODO LETIVO E FÉRIAS 77

TABELA 25: LisTA DE PRIORIDADES FINAL - INCIDÊNCIA DE INDICADORES 94

TABELA 26: LISTA DE PRIORIDADES FINAL - INCIDÊNCIA DE INDICADORES POR ESPECIALIDADE 94 


\section{ABREVIATURAS UTILIZADAS}

CUASO CIDADE UNIVERSITARIA ARMANDO DE SALES OLIVEIRA

ANEEL AGÊNCIA NACIONAL DE ENERGIA ELÉTRICA

CCEE CÂMARA DE COMERCIALIZAÇÃO DE ENERGIA ELÉTRICA

USP UNIVERSIDADE DE SÃO PAULO

PUREUSP PROGRAMA PARA O USO EFICIENTE DE ENERGIA NA USP

GEPEA GRUPO DE ENERGIA DO DEPARTAMENTO DE ENGENHARIA DE ENERGIA E AUTOMAÇÃO ELÉTRICAS DA ESCOLA POLITÉCNICA DA UNIVERSIDADE DE SÃO PAULO

UC UNIDADE CONSUMIDORA

PROCEL PROGRAMA NACIONAL DE CONSERVAÇÃO DE ENERGIA ELÉTRICA

COESF COORDENADORIA DO ESPAÇO FÍSICO DA USP

ONS OPERADOR NACIONAL DO SISTEMA 
1.1. MOTIVAÇõES

1.2. OBJETIVOS 8

1.3. ESTRUTURA 9

2. A GESTÃO DA ENERGIA E A UTILIZAÇÃO DE INDICADORES

2.1. GESTÃo DE ENERGIA - VISÃo GERAL 12

2.2. CONCEITUAÇÃO E UTILIZAÇÃO DOS INDICADORES ENERGÉTICOS

2.3. INDICADORES GLOBAIS

2.3.1. FATOR DE CARGA $\quad 15$

2.3.2. FATOR DE POTENNCIA

2.3.3. INDICADOR DE USO DA ENERGIA POR HORÁRIOS DE UTILIZAÇÃO

2.4. INDICADORES ESPECÍFICOS

2.4.1. INDICADOR POR USUÁRIO DA ENERGIA

2.4.2. INDICADOR POR ÁREA EDIFICADA 21

2.4.3. INDICADORES POR USO FINAL DA ENERGIA

2.5. INDICADORES FINANCEIROS

3. METODOLOGIA DE UTILIZACÃ̃ DE INDICADORES DE CONSUMO COMO REFERÊNCIA DE ACÕES DE EFICIÊNCIA ENERGÉTICA.

3.1. CARACTERIZAÇÃO DAS UNIDADES POR INDICADORES GLOBAIS 26

3.2. CARACTERIZAÇÃO DE UNIDADES POR INDICADORES ESPECÍFICOS 29

3.2.1. INDICADOR POR USO DA ILUMINAÇÃO

3.2.2. INDICADOR POR USO DE SISTEMAS DE AR-CONDICIONADO E REFRIGERAÇÃO 32

3.2.3. INDICADOR POR USO DE EQUIPAMENTOS DE INFORMÁTICA 36

3.2.4. INDICADOR POR UTILIZAÇÃO DE OUTROS EQUIPAMENTOS 39

3.3. AValiaÇão e AtuaÇão com Base na Lista de Prioridades 39

4. O EXEMPLO DE GESTÃO NA UNIVERSIDADE DE SÃO PAULO

4.1. O CONSUMO DE ENERGIA NA USP

4.2. A GESTÃO DA ENERGIA NA USP

4.3. FERRAMENTAS UTILIZADAS

4.3.1. CONTALUZ WEB 44

4.3.2. SISGEN 46

4.4. PRINCIPAIS USOS FinaIS

4.4.1. ILUMINAÇÃO 48

4.4.2. AR-CONDICIONADO 49

4.4.3. OUTROS EQUIPAMENTOS

5. APLICAÇ̃̃O DA METODOLOGIA NA CIDADE UNIVERSITÁRIA ARMANDO DE \begin{tabular}{lr} 
SALES OLIVEIRA - CUASO. & 52 \\
\hline
\end{tabular} 
5.1. PeRFIL DE MONITORAMENTO - CUASO.

5.2. ClASSIFICAÇÃO POR FATOR DE POTÊNCIA

5.3. CLASSIFICAÇÃO POR FATOR DE CARGa

5.4. CLASSIFICAÇÃO POR HORÁRIOS DE UTILIZAÇÃO

5.5. CLASSIFICAÇÃO - INDICADOR POR USUÁRIOS DA ENERGIA

5.6. CLASSIFICAÇÃO - INDICADOR POR ÁREA EDIFICADA

5.7. CLASSIFICAÇÃO - INDICADOR POR USO FINAL - SISTEMAS DE REFRIGERAÇÃO E AR CONDICIONADO

5.8. CLASSIFICAÇÃO - INDICADOR POR USO FINAL - SISTEMAS DE ILUMINAÇÃO

5.9. CLASSIFICAÇÃO - INDICADOR POR USO FINAL - EQUIPAMENTOS DE INFORMÁTICA 72

5.10. CLASSIFICAÇÃO POR INDICADOR FINANCEIRO

6. $\quad$ ANÁLISE DOS RESULTADOS

6.1. INDICADORES GLOBAIS

6.1.1. FATOR DE POTÊNCIA $\quad 79$

6.1.2. FATOR DE CARGA $\quad 80$

6.1.3. CONSUMO POR HORÁRIOS DE UTILIZAÇÃO 81

6.2. INDICADORES ESPECÍFICOS 82

6.2.1. CONSUMO POR USUÁRIOS DA ENERGIA

6.2.2. CONSUMO POR ÁREA EDIFICADA 84

6.2.3. CONSUMO POR USO FINAL - SISTEMAS DE REFRIGERAÇÃO E AR CONDICIONADO 84

6.2.4. CONSUMO POR USO FINAL - SISTEMAS DE ILUMINAÇÃO 86

6.2.5. CONSUMO POR USO FINAL - EQUIPAMENTOS DE INFORMÁTICA 86

6.2.6. CUSTOS COM ENERGIA ELÉTRICA

7. $\quad$ CONCLUSÕES E DESENVOLVIMENTOS FUTUROS

7.1. SUGESTÃO PARA DESENVOLVIMENTOS FUTUROS 95

8. REFERÊNCIAS BIBLIOGRÁFICAS 96 


\section{INTRODUÇÃO}

$\mathrm{Na}$ maior parte das atividades de desenvolver, produzir, criar, ensinar e em outras, a eletricidade esta presente em diversas etapas, iluminando, movimentando, processando, ou seja, permitindo, facilitando e proporcionando conforto aos usuários da energia, por ela produzida. Atualmente é uma das fontes de energia secundária mais utilizada em todo o mundo, o que a torna muito importante para a economia e manutenção de diversos setores, na maioria dos países.

Nos casos em que a energia elétrica é utilizada nos processos, essa passa a ser parte dos custos, de qualquer que seja o produto ou serviço realizado com sua contribuição. Sendo assim, controlar os gastos com energia elétrica se torna importante em todas as instalações que façam seu uso, melhorando a competitividade diante ao mercado, reduzindo seus custos na produção ou prestação de serviços. Além de diminuir os gastos com energia, este controle contribui também com a preservação do meio ambiente, no que diz respeito à expansão dos sistemas de geração, transmissão e distribuição da energia elétrica.

As ações que visam a minimização dos custos com esse insumo, geralmente, não são simples e requerem estudos e análises de informações físicas e dos usos finais de energia, nas unidades. Em muitos casos, as ações provenientes dos estudos voltados aos equipamentos e estruturas físicas dos locais que utilizam energia elétrica não são atrativas economicamente, por não reduzirem significativamente os gastos, a ponto de justificar a implantação de novas tecnologias e programas que visam a eficiência energética, devido ao tempo de retorno do investimento inicial. No entanto, 
outros parâmetros podem ser considerados para viabilizar as ações de eficiência, dependendo da política e objetivos das instituições, como por exemplo, às questões de preservação do meio ambiente, melhoria das condições de trabalho e outras.

Desta forma, por envolver diversas áreas de atuação, o que exige uma equipe qualificada, ferramentas de apoio e uma direção administrativa comprometida com tais questões, algumas instituições cometem o equívoco de simplesmente ignorar os potenciais de economia que possuem, transferindo assim os custos com o uso da eletricidade para seus produtos e serviços. No entanto, alguns exemplos de sucesso demonstram que a união de equipes bem qualificadas, com o apoio e orientação administrativa necessários, podem proporcionar grandes resultados no que diz respeito a evitar gastos desnecessários com a utilização da eletricidade.

Baseados nos casos bem sucedidos de atuação em eficiência energética encontram-se vários termos utilizados para controle de gastos com energia elétrica.
A eficiência energética apresenta atualmente uma diversidade de conceitos, estando geralmente associadas à dicotomia medidas implementadas/resultados alcançados na redução do crescimento da procura de energia, ou seja, de uma melhor utilização final da energia. Conceitos como conservação de energia, utilização racional de energia, gestão de energia, gestão da procura de energia, estão associados à eficiência energética (Ferreira, 1995, p. 3).

Embora seja de grande importância, a eficiência energética ainda é um assunto recente para muitos países, instituições e consumidores de energia. Algumas 
referências apontam que, as ações de racionalização de energia foram impulsionadas a partir das primeiras crises do petróleo na década de 70, “... que teve como conseqüência, dentre outras, lembrar que a energia é um bem esgotável, escasso e com preços altamente instáveis (Ferreira e Ferreira, 1994, p. 11)". A partir desse momento, diversos países tomaram consciência da dimensão da fragilidade da economia, em relação aos meios de energia utilizados em diversos setores.

Isso evidencia que, seja qual for a energia utilizada, esta deve ser encarada como um bem a ser preservado e utilizado de forma consciente:
A energia, como instrumento que permite dar satisfação às necessidades criadas pelo desenvolvimento socioeconômico, desempenha um papel fundamental nas economias e por isso deve ser encarada como um bem a ser utilizado de forma eficiente e racional, integrando-se na perspectiva abrangente da utilização racional dos recursos (Ferreira e Ferreira, 1994, p. 11).

As adversidades encontradas nas épocas de crises iniciaram um processo de busca a alternativas, que diminuíssem a fragilidade dos setores da economia perante as crises dos insumos energéticos. Nesta busca, houve a evolução da tecnologia de equipamentos, na exploração e distribuição dos recursos naturais, usos finais e fontes alternativas para geração de energia.

Muito se avançou nos aspectos tecnológicos, porém, as alternativas são, em muitos casos, de custo elevado, o que não viabiliza a implementação em curto e médio prazo e, sendo assim, as ações de conscientização para o uso racional se 
tornam o meio de menor custo, que pode gerar benefícios em curto, médio e longo prazo.

Alguns exemplos internacionais podem ser citados como referências de ações de combate ao desperdício de energia. O trabalho realizado por FARINHA, et. al, (1988), além de apresentar de forma organizada a dependência de diversos setores da economia portuguesa, em relação às fontes de energia, traça um plano com várias diretrizes, mais voltadas às pequenas e médias empresas, estimando os potenciais de economia e qual o percentual de participação da energia no preço final do produto. Em AEBISCHER, et. al. (2003) é realizado um estudo em restaurantes, em diversos países, comparando o consumo e criando indicadores para o setor, baseados nas informações físicas e comportamentais, com o objetivo de subsidiar as ações de eficiência no uso da energia.

Outros estudos são realizados no sentido de classificar os setores em relação ao consumo de energia, voltados às questões do meio ambiente, como por exemplo, (SCHIPPER, et. al. 2001; WORLD ENERGY COUNCIL, 2001; UYTERLINDE, 2000). Em alguns casos, são apresentadas oportunidades de redução do uso da energia, com a utilização de tecnologias mais avançadas, que vão desde a geração até os usos finais, com o intuito de reduzir a emissão de gases de efeito estufa e garantir o desenvolvimento sustentável.

No caso específico do Brasil, a consciência de racionalização começou a ser difundida na década de 80, com estudos e ações pontuais de eficiência energética e, em dezembro de 1985, pelo Ministério de Minas e Energia e da Indústria e Comércio, 
criou-se o PROCEL, Programa Nacional de Conservação de Energia Elétrica, inicialmente gerido por uma Secretaria Executiva subordinada à Eletrobrás.

"Criado com o objetivo de promover a racionalização da produção e do consumo de energia elétrica, para que se elimine o desperdício e se reduzam os custos e os investimentos setoriais." (PROCEL $\left.{ }^{1}, 2006\right)$, o PROCEL atua em diversos setores, desde a educação e conscientização sobre o uso da energia elétrica até o combate às perdas nos sistemas de geração, transmissão e distribuição de energia, passando por iniciativas de classificar equipamentos em escalas de eficiência (etiquetagem), orientando os consumidores no momento da aquisição.

No processo de evolução do programa, algumas preocupações foram o foco das ações, assim houve o interesse nas pesquisas e desenvolvimentos tecnológicos, a incorporação de novas tecnologias ao acervo científico e tecnológico, a promoção de assistência tecnológica ao segmento industrial, da conservação de energia elétrica através da normalização, padronização e certificação de equipamentos. Assim, através da análise destas questões, percebeu-se que o PROCEL apresentava um razoável potencial no combate ao desperdício de energia elétrica, apesar de seu caráter setorial e, após a fase inicial de implantação e identificação de potenciais, foi transformado em programa de governo.

Em 18 de julho de 1991, por Decreto Presidencial, o PROCEL deixou de ser um programa setorial e foi transformado em Programa de Governo, tendo sua abrangência e responsabilidades ampliadas, com

1 http://www.eletrobras.gov.br/procel - Acesso: 04/2006 
interações e repercussões diretas na sociedade como um todo. O Programa passou a não se restringir apenas ao setor elétrico, articulando-se, a partir de então, com todos os segmentos da sociedade direta ou indiretamente ligados à produção e ao uso da energia elétrica (ANEEL/ANP, 1999).

Embora as iniciativas de eficiência energética no Brasil, através do PROCEL, tenham sido iniciadas na década de 80 , este tema não atingiu todos os potenciais de economia de energia que o país possuía e, um acontecimento importante, no ano de 2001, foi que o colocou em destaque. Nos anos de 2001 e 2002 o país sofreu o racionamento de energia, na maioria das regiões do país. Este racionamento seja por falta de investimentos no setor, por falta de planejamento ou a falta de eficiência no uso da energia, marcou, profundamente, o histórico do consumo de energia no país, sendo que, metas de redução do consumo foram impostas pelo governo, que obrigou os consumidores a mudanças radicais em seus hábitos, com a pena de cobrança de penalidades pelo não cumprimento de tais metas.

A partir deste episódio, muito se mudou no consumo de energia elétrica no país, seja na indústria, comércio ou nas residências. Embora a redução tenha sido imposta pelo governo federal, esta mudança, evidenciou a existência de grandes potenciais de redução no consumo em diversos setores. No entanto, quanto mais distante fica a lembrança deste acontecimento, mais os hábitos de utilização racional se depreciam, sugerindo que as ações de eficiência energética devem ser constantes em um processo de atualização. Esta tendência mostra que uma Gestão efetiva pode manter os bons hábitos e promover, cada vez mais, as ações de combate ao desperdício. 
Seja qual for o ramo de atividade, no processo de gestão da energia elétrica, vários aspectos devem ser levados em consideração para apoiar as decisões e ações, no que diz respeito ao uso eficiente. Sendo assim, é necessário conhecer bem as instalações e os processos que utilizam a energia elétrica. Este conhecimento prévio vai desde os equipamentos até os contratos firmados com as concessionárias, permissionárias ou comercializadoras de energia.

Algumas ferramentas de apoio são necessárias para que os gestores das unidades conheçam o comportamento e hábitos de uso da energia. Dentre as ferramentas podem-se citar as ferramentas de gestão de faturas e monitoramento do consumo, que criam um histórico das unidades e fundamentam as decisões e estimativas dos responsáveis pela gestão. Outra ferramenta importante são os indicadores de consumo, que podem ser estabelecidos através de dados históricos ou a partir da classificação da unidade e seus usos finais.

Os indicadores baseados no consumo da energia elétrica nas unidades consumidoras ainda não são amplamente utilizados nos processos de gestão dos recursos destinados a energia. No entanto, diversos trabalhos foram realizados no intuito de encontrar os indicadores que auxiliassem no controle e acompanhamento do consumo, porém, devido à dificuldade no levantamento das informações necessárias, a quantidade de equipamentos utilizados em uma única unidade e as particularidades da utilização, geralmente os indicadores figuram em segundo plano nos processos de gestão da energia. 


\subsection{Motivações}

A motivação para este trabalho deve-se as ferramentas de monitoramento de consumo e gestão de faturas na USP, que geram uma quantidade expressiva de informações de diversas unidades consumidoras com atividades semelhantes, mas com particularidades devido às especificidades das unidades e hábitos de utilização da energia elétrica. As informações provenientes destas ferramentas servem de base para o processo de gestão da energia nos campi da universidade, realizadas pelo pureusp (Programa para o Uso Eficiente de Energia na USP). Exemplo de sucesso na gestão dos recursos destinados à energia elétrica, o pureusp desenvolve diversas atividades como palestras para conscientização dos usuários, gestão de contratos celebrados com as concessionárias, aplicação de projetos de eficiência energética nas unidades e outras.

Após uma classificação prévia das unidades, a grande quantidade de dados oriunda das ferramentas de apoio possibilita a geração de indicadores, que podem auxiliar os gestores nas ações de eficientização do uso da energia nas instalações da USP e em outras com características semelhantes.

\subsection{Objetivos}

O objetivo deste trabalho é elaborar uma classificação de unidades consumidoras utilizando indicadores de consumo, com base nos dados históricos de consumo de energia elétrica.

A partir das informações de consumo de energia elétrica, extraídas da ferramenta de gestão de consumo da USP e das informações físicas, de ocupação e 
utilização das unidades, extraídas do anuário da universidade o objetivo é utilizar indicadores que abordem os principais usos finais das instalações, caracterizá-las por suas especificidades e semelhanças na utilização da energia, e assim, auxiliar na priorização das ações de gestão e eficiência energética.

O estudo de caso na Cidade Universitária Armando de Sales Oliveira - CUASO, que possui monitoramento de grande parte de seu consumo de energia elétrica, possibilitará a comparação entre unidades e validar a proposta.

\subsection{Estrutura}

A Metodologia proposta foi desenvolvida a partir de estudos e pesquisas realizadas no GEPEA $^{2}$ e utilização das ferramentas de gestão utilizadas nos processos do pureusp.

Inicialmente, no capítulo 2, são apresentadas noções e definições de gestão da energia elétrica, assim como os principais indicadores energéticos. O objetivo dessa exposição é fornecer informações básicas dos conceitos de gestão e descrever os indicadores utilizados.

A metodologia de utilização de indicadores energéticos, como referência de ações de eficiência energética, é apresentada no capítulo 3. Esta metodologia tem como objetivo auxiliar os gestores ou equipes de gestão a caracterizar unidades consumidoras, por suas especialidades, ramos de atuação, informações físicas,

\footnotetext{
${ }^{2}$ Grupo de Energia do Departamento de Engenharia de Energia e Automação Elétricas da Escola Politécnica da Universidade de São Paulo.
} 
demográficas, usos finais e pelos hábitos no uso da energia elétrica, através de aplicação de indicadores energéticos. Esta caracterização auxiliará na elaboração de uma lista de prioridades de atuação, visando o auxilio da gestão e ações de eficiência na utilização da energia elétrica.

Exemplo de Gestão bem sucedido, no capítulo 4 se tem um resumo das ações adotadas no combate ao desperdício de energia elétrica e as principais características da Universidade de São Paulo. Em (SAIDEL, 2005) é detalhada a utilização de energia elétrica em todos os campi da USP e as experiências com a gestão deste insumo. Nesta exposição, são citadas as ferramentas utilizadas pelos gestores, que são base de estudos e auxiliam no processo de controle dos gastos com energia elétrica.

No capitulo 5, os indicadores são aplicados às informações da CUASO e criada uma lista de prioridades de atuação para cada um dos indicadores utilizados.

A análise dos resultados obtidos com a aplicação dos indicadores é realizada no capitulo 6 para facilitar as conclusões e comentários descritos no capítulo 7. 


\section{A GESTÃO DA ENERGIA E A UTILIZAÇÃO DE INDICADORES}

O termo gestão é definido com o ato de gerir, ou seja, gerenciar e administrar e, vem sendo utilizado em vários seguimentos de ramos de atividade diferenciados, como sendo a forma ou metodologia para melhorar processos e organizar procedimentos de maneira a obter o menor custo e a melhor qualidade de produtos e serviços. São associadas a este termo, várias técnicas e ferramentas para auxiliar as decisões dos responsáveis pela gestão.

Na área de utilização de energia elétrica, a definição da gestão está diretamente ligada ao uso eficiente e, geralmente, as ferramentas utilizadas no processo de busca e manutenções da eficiência no uso da energia são aquelas que fornecem informações essenciais para fundamentar as decisões dos gestores, como por exemplo, as de gerenciamento de consumo, que criam o histórico de consumo de energia da unidade em relação a utilização e os usos finais da eletricidade, gerando relatórios e gráficos, utilizados para o acompanhamento e verificação da eficiência das iniciativas aplicadas às unidades monitoradas e identificação de comportamentos de uso. Outra ferramenta importante é a de gestão das faturas, emitidas pela concessionária, permissionária ou comercializadora de energia, que além de criar o histórico de consumo da unidade com as informações dos períodos de faturamento, são importantes para a gestão financeira, evitando multas por atrasos nos pagamentos e eventualmente corrigindo falhas de cobrança.

As informações provenientes das ferramentas de apoio ou a partir de levantamentos nas unidades podem ser utilizadas para gerar indicadores que em 
diversos ramos de atividade são utilizados como referência, para auxiliar na identificação de potenciais de economia e tendências de mudança no comportamento. Podem-se citar vários exemplos de utilização de indicadores, como na economia de um país, crescimento populacional, custo por produção e vários outros. Com a energia elétrica acontece de forma semelhante, vários indicadores energéticos são utilizados para verificar e controlar os gastos com este insumo, visando a eficiência.

SCHIPPER et. al. (2001), em um trabalho de comparação de vários seguimentos de uso da energia em vários países, com relação à emissão de $\mathrm{CO}_{2}$, define que os indicadores da energia descrevem as ligações entre o uso da energia e a atividade humana em uma estrutura desagregada. São essencialmente medidas do consumo de energia e dos fatores subjacentes que dirigem esse consumo. Cita ainda que as relações de energia consumida por unidade de uma dada atividade são utilizadas a fim de detectar as mudanças na eficiência da energia e que o cálculo das intensidades da energia desagregada requer dados detalhados da atividade realizada.

\subsection{Gestão de Energia - Visão Geral}

Embora o termo gestão seja largamente utilizado, nem sempre é aplicada de maneira coerente e, em inúmeras oportunidades, este termo é definido somente como sendo parte de processos cotidianos e em algumas vezes até associado a membros ou líderes de equipes e administradores. Algumas definições podem ser encontradas para o tema, como em FERREIRA e FERREIRA (1994), que define que gerir energia consiste em conhecer os consumos energéticos (por que, como, onde e quando se consome energia), contabilizar e seguir a evolução dos consumos de energia, dispor 
de dados para a tomada de decisão, agir para otimizar e controlar o resultado das ações e investimentos realizados. Em SAIDEL (2005), a gestão é conceituada da seguinte forma:

A gestão de energia pode ser conceituada como um conjunto de fundamentos, técnicas e ferramentas de ordenamento e conservação de energia, visando seu aproveitamento ótimo em bases sustentáveis, viabilizando estratégias de solução de problemas sócio-ambientais presentes e futuros, minimizando a ocorrência de conflitos e sustentabilizando as atividades econômicas, conservando simultaneamente os ecossistemas envolvidos.

Sendo assim, a gestão pode ser definida de inúmeras maneiras, levando em consideração os objetivos a alcançar. No entanto, pode-se, de forma geral, apresentála como sendo o conjunto de informações e experiências extraídas de processos, ferramentas, participação pessoal em atividades correlatas (experiência profissional), com contribuições de intuição e criatividade, que indicam ou subsidiam determinada equipe, departamento ou instituição a agir visando o benefício global, seja ele institucional, financeiro ou social.

\subsection{Conceituação e Utilização dos Indicadores Energéticos}

Os indicadores de consumo ou indicadores energéticos são os resultados do cruzamento de informações físicas ou administrativas, com as grandezas elétricas medidas/registradas ou custos/gastos da energia de determinado país, região, ramo de atividade, unidade ou usos finais. 
Os indicadores podem ser definidos e classificados de várias formas, como ANEEL/ANP (1999, P.246), que define os indicadores, baseados em alguns critérios, como sendo "... instrumentos de comunicação de informações quantitativas sobre a sustentabilidade de sistemas energéticos para tomadores de decisões e o grande público...".

Em FERREIRA e FERREIRA (1994), os indicadores são estabelecidos através de relações e de variáveis que podem ser usadas ao nível macro e micro com o objetivo de monitorar as variações e desvios na eficiência energética dos sistemas e, classifica-os como macroindicadores, nos casos em que são utilizados dados de um país, região, ramo de atividade ou uso final e microindicadores, nos casos de aplicações em edifícios, indústrias ou residências. Neste mesmo trabalho, os indicadores são separados ainda em dois grandes grupos, sendo os descritivos, que caracterizam a situação de eficiência energética sem procurar a justificativa para as suas alterações ou desvios e os explicativos, que explicam as razões pelas quais se deram variações ou desvios nos indicadores descritivos.

De forma geral, os indicadores podem ser classificados em dois grandes grupos, de indicadores globais e específicos, levando em consideração as informações físicas das unidades ou setores a serem caracterizados, porém, há também os indicadores financeiros, que podem ser associados aos globais e específicos, demonstrando os custos de acordo com a utilização da energia elétrica.

Alguns indicadores mais simples podem ser extraídos das faturas de energia ou de uma medição paralela, especialmente nos casos de atendimento em tensão de 
distribuição secundaria $\left(\right.$ Grupo $B^{3}$ ), pois são submetidos a tarifação do tipo monômia em que são se obtém apenas os valores de consumo. Outros podem ser encontrados em estudos e trabalhos realizados, como em FAVATO (2005) e ALVAREZ (1998).

\subsection{Indicadores Globais}

Os indicadores classificados como globais caracterizam a instalação ou unidade a partir das questões técnicas, apontando a eficiência do uso da energia elétrica de uma forma geral. Alguns indicadores globais são utilizados na fase inicial de caracterização, identificando problemas nas instalações, do ponto de vista técnico ou comportamental.

\subsubsection{Fator de Carga}

O Fator de Carga, obtido através das faturas de energia ou medições paralelas, mostra como a energia elétrica é utilizada em uma determinada instalação, no que diz respeito à demanda de potência, e pode ser calculado, para um determinado intervalo de tempo:

$$
F C=\frac{D_{\text {med }}}{D_{\max }}=\frac{E}{t \times D_{\max }}
$$

Em que:

- $D_{\max }$, é o máximo valor da demanda de potência no intervalo de tempo $t$;

3 Grupo "B": grupamento composto de unidades consumidoras com fornecimento em tensão inferior a

2,3 kV, ou, ainda, atendidas em tensão superior a 2,3 kV e faturadas neste Grupo nos termos definidos nos arts. 79 a 81, caracterizado pela estruturação tarifária monômia e subdividido nos seguintes subgrupos... (ANEEL, 2000) 
- $D_{\text {med }}$, é o valor médio da demanda de potência no mesmo intervalo de tempo; e

- $\quad E$, corresponde à energia consumida neste intervalo.

Quanto mais próximo da unidade, o fator de carga indica que a energia é consumida com valores médios de potência próximos dos valores máximos, no intervalo de tempo considerado e, quanto mais próximo de zero indica que a energia é consumida com os valores máximos de potência, distantes dos valores médios, com exceção de casos específicos, durante maior parte do intervalo.

Desta forma, para os consumidores enquadrados na estrutura tarifária do Grupo $A^{4}$, levando em consideração os valores de contratação de demanda, perante a concessionária, pode-se dizer que quanto mais próximo da unidade for o Fator de Carga, menor será o custo unitário da energia consumida.

\subsubsection{Fator de Potência}

O fator de potência de uma unidade ou instalação deve ser considerado como um indicador energético importante, pois pode auxiliar na avaliação do dimensionamento dos equipamentos alimentadores, do ponto de vista de sobrecarga. Nos casos de verificação de valores abaixo do mínimo especificado em norma, acarreta em penalidades aplicadas pela concessionária de energia.

${ }^{4}$ Grupo "A": grupamento composto de unidades consumidoras com fornecimento em tensão igual ou superior a 2,3 kV, ou, ainda, atendidas em tensão inferior a 2,3 kV a partir de sistema subterrâneo de distribuição e faturadas neste Grupo nos termos definidos no art. 82, caracterizado pela estruturação tarifária binômia e subdividido nos seguintes subgrupos...(ANEEL, 2000) 
A correção do fator de potência, nos casos em que houver a identificação de valores abaixo do especificado ou quando necessária em expansões da unidade, do ponto de vista do uso da eletricidade, é importante para evitar perdas nos equipamentos de alimentação e penalidades por baixos valores.

O valor médio de fator de potência, nos casos de consumidores do Grupo A, pode ser obtido com as informações provenientes das faturas de energia elétrica emitidas pela concessionária. Porém, para realizar a correção, quando necessária, geralmente é necessária uma medição que registre os valores de energia ativa e reativa nos intervalos de integração de 1 (uma) hora (ANEEL, 2000), podendo ser obtido através da razão entre a energia elétrica ativa e a raiz quadrada da soma dos quadrados das energias elétricas ativa e reativa:

Em que:

$$
F P=\frac{E a}{\sqrt{E a^{2}+E r^{2}}}
$$

- $\quad E a$, Energia ativa consumida no intervalo de tempo, em kWh;

- $E r$, Energia reativa consumida no mesmo intervalo de tempo, em kVAr.

\subsubsection{Indicador de uso da energia por horários de utilização}

A caracterização pelo horário de utilização da energia, leva em consideração a sazonalidade de consumo e a baixa atividade em determinados horários. Este tipo de indicador destaca a parcela de consumo nos horários de baixa atividade, em comparação com os de maior atividade, auxiliando na identificação do tipo de equipamentos mais utilizados nos períodos. 
FAVATO (2005), um trabalho que aplica diversos indicadores globais em unidades de ensino superior, classifica a utilização por horário como PCR (Índice Percentual de Consumo Noturno verificado no Período de Faturamento Reservado) e tem por objetivo caracterizar qual é o impacto do consumo noturno, observado durante o Período Reservado de uma Unidade Consumidora (UC), no Consumo Total:

$$
P C R=\frac{\text { Energia no periodo reservado }(k W h)}{\text { Energia total da instalação }(k W h)} \text { (3) }
$$

Este indicador pode ser aplicado nos horários de ponta e fora de ponta, ou em períodos determinados, no entanto, é necessário que as informações de consumo sejam separadas nos horários de interesse. Algumas destas informações podem ser obtidas das faturas de energia ou através de uma ferramenta de apoio que requisite as informações de potência ao longo do dia.

Ainda em FAVATO (2005), outros indicadores são utilizados para comparar a demanda máxima dos períodos verificados, em que, aliados às informações de ocupação e funcionamento das unidades, auxilia na avaliação dos contratos e futuros projetos de novas instalações.

\subsection{Indicadores específicos}

Os indicadores específicos têm a finalidade de avaliar o comportamento de uso da energia elétrica de determinada instalação, levando em consideração as informações físicas, de ocupação e os usos finais. Geralmente, os resultados são utilizados para comparações em instalações semelhantes e para conscientização e orientação dos usuários. 
O acompanhamento e atualização dos indicadores específicos pode identificar tendências de mudanças no comportamento, podendo assim auxiliar na renovação contratual das unidades e na avaliação da eficácia das ações de redução de consumo aplicadas nas instalações.

\subsubsection{Indicador por usuário da energia}

O indicador por usuário da energia pode ser calculado dividindo-se o consumo em um determinado período pelo número de usuários da unidade. Levando em consideração a ocupação total, com os horários de funcionamento e o consumo total em determinado período, se obtém o consumo médio por usuário. Este tipo de indicador, na maioria dos casos, não aponta qual o real comportamento de uso da energia elétrica na unidade, no entanto, a segregação dos usuários em setores, cargos e horários de funcionamento, pode auxiliar na identificação dos reais potenciais e quais os focos das ações de eficiência energética.

Os usuários podem ser separados por área, setor, departamento, cargo e outros, desde que se obtenha a parcela de consumo do grupo de usuários, como em ALVAREZ (1998), em que são apresentados alguns indicadores levando em consideração grupos de usuários separados em docentes e alunos, como por exemplo, o indicador Docente Equivalente (DE) e Aluno Equivalente (AE).

O número de Docente e Aluno equivalente leva em consideração o tempo de permanência dos usuários nas dependências da unidade: 


$$
D E=\sum_{i=1}^{n} \frac{N i * h i}{40}(4)
$$

Em que:

- $\quad N i$, é o número de docentes no regime de trabalho $i$;

- $\quad h i$, é o número de horas do regime de trabalho $i$; e

- $\quad n$, número de regimes de trabalho diferentes.

$$
A E=\sum_{i=1}^{n} \frac{N i * h i}{40}(5)
$$

Em que:

- $\quad N i$, é o número de alunos no regime de estudo $i$;

- hi, é o número de horas do regime de estudo $i$; e

- $n$, número de regimes de estudo diferentes.

ALVAREZ (1998) utiliza as informações de Aluno e Docente equivalente no cálculo do indicador energético mensal por usuários. De maneira mais abrangente pode-se apresentar o indicador por usuário:

Em que:

$$
\text { Iue }=\frac{E n}{U s . t}(6)
$$

- En, é a energia consumida no intervalo de tempo $t$, expresso em $\mathrm{kWh}$;

- Us, é o número total ou grupo de usuários que utilizam a energia; e

- $\mathrm{t}$, corresponde ao período analisado. 
Estes indicadores podem ser utilizados para analisar o perfil de consumo dos usuários da energia, e tomando-se como referência um valor padrão, de acordo com o tempo de utilização e o estilo do consumo de cada tipo de usuário, é possível identificar potenciais de redução aliados aos hábitos de uso da energia.

\subsubsection{Indicador por área edificada}

O indicador por área edificada é obtido da razão do consumo de energia em um determinado período, pelo produto da área útil e o intervalo de tempo verificado:

Em que:

$$
\operatorname{Iar}=\frac{E n}{A . t}(7)
$$

- En, é a energia consumida no intervalo de tempo $t$, expresso em $\mathrm{kWh}$;

- A, é a Área útil da unidade ou ambiente que utiliza a energia expresso em $\mathrm{m}^{2} ; \mathrm{e}$

- $\mathrm{t}$, corresponde ao período analisado.

Este indicador pode ser utilizado na comparação de instalações que tenham atividades semelhantes. Assim, podem-se obter números (baseados em unidades modelos ou metas a atingir) de uma unidade padrão ou referência e, comparando os números obtidos em outras unidades, verificar a eficiência do uso da energia e seus potenciais de economia. 


\subsubsection{Indicadores por uso final da energia}

De maneira análoga, é possível utilizar indicadores por uso final utilizado na instalação verificada. Este tipo de indicador requer um levantamento prévio, com o intuito de desagregar o consumo em seus usos finais. Várias técnicas podem ser aplicadas para o levantamento e desagregação de consumo, que não são levadas em consideração neste tópico.

O indicador por uso final pode ser obtido a partir da razão da energia consumida no uso final específico (iluminação, climatização de ambientes e outros) em um determinado período, pelo produto de uma variável específica (área útil, usuários, produção e outros) e o período analisado.

Em que:

$$
I u f=\frac{E u f}{V e^{*} t}(8)
$$

- Euf, é a energia consumida no uso final específico, no intervalo de tempo $t$, expresso em kWh;

- Ve, variável específica utilizada no indicador; e

- $\quad \mathrm{t}$, corresponde ao período analisado.

De maneira análoga ao indicador por área edificada, os indicadores por uso final auxiliam a estabelecer padrões e referências de consumo. Desta forma, estes indicadores podem auxiliar na escolha de tecnologia na aquisição de equipamentos, verificação da eficiência dos equipamentos em funcionamento e comparação com 
outras unidades para verificar a eficiência e os potenciais de economia na utilização da energia elétrica.

\subsection{Indicadores Financeiros}

Os indicadores financeiros, tratando-se de energia elétrica, podem mostrar como os recursos são distribuídos dentro de uma determinada unidade consumidora. Aplicados ao longo do tempo, os resultados obtidos de ordem crescentes não indicam com certeza que houve aumento no consumo ou falta de eficiência no uso.

$$
\begin{aligned}
& \text { Na linguagem coloquial, muitas vezes, a referência ao termo } \\
& \text { "Conservação de Energia" ou "Economia de Energia" ocorre com o } \\
& \text { sentido de economia de recursos. Essa conotação precisa ser } \\
& \text { discutida: o custo da energia, em particular da elétrica, cresceu acima } \\
& \text { da inflação acumulada nos últimos dez anos e deve permanecer nesta } \\
& \text { tendência em função das regras de reajustes tarifários e regras de } \\
& \text { tributação do setor (SAIDEL, 2005). }
\end{aligned}
$$

(SAIDEL, 2005) alerta para o crescimento constante dos custos no uso da energia elétrica, sendo assim, o aumento dos custos ao longo do tempo poderá ser verificado com a aplicação de indicador financeiro, comparando a proporção dos recursos destinados à parte, em relação ao total da unidade, no uso da energia elétrica, levando em consideração as informações de área edificada, usos finais e usuários da energia. 
Em que:

$$
I f i n=\frac{\left(C T * \frac{E n}{E N T}\right)}{V e^{*} t}
$$

- CT é o custo total com energia elétrica;

- En é a parcela do total da energia consumida, da parte verificada, no intervalo de tempo $t$, expresso em $\mathrm{kWh}$;

- ENT é a energia total do ambiente verificado;

- Ve, variável específica (usuários, área e etc); e

- $\mathrm{t}$, corresponde ao período analisado.

Os resultados obtidos com os indicadores financeiros auxiliam na verificação das evoluções nos custos com energia elétrica e a parcela de contribuição das unidades, usos finais, usuários e outros, nas evoluções. 


\section{METODOLOGIA DE UTILIZAÇÃO DE INDICADORES DE CONSUMO COMO REFERÊNCIA DE AÇÕES DE EFICIÊNCIA ENERGÉTICA.}

A metodologia descrita a seguir tem o intuito de caracterizar unidades consumidoras, a partir de seu histórico de consumo e aplicação dos principais indicadores energéticos. Tem o intuito de auxiliar na gestão do consumo de energia elétrica, priorizando as ações de eficiência e combate ao desperdício nas unidades com maiores potenciais de economia de energia elétrica. No entanto, a aplicação desta metodologia não extinguirá um diagnóstico energético aprofundado nas unidades, no entanto, possibilitará aos gestores, o conhecimento prévio dos potenciais de redução e quais as ações necessárias para atingir os objetivos desejados.

A caracterização inicial das unidades pode ser realizada através das informações físicas (área de utilização), finalidades da utilização (produtos, prestação de serviços e outros), equipamentos utilizados, quantidade de usuários e tempo de utilização, pois estão diretamente associadas aos hábitos de uso da energia.

Além de essenciais na caracterização inicial da unidade, essas informações são importantes para elaborar indicadores e planos de ação que visam tornar as instalações mais eficientes, do ponto de vista do uso da eletricidade.

A metodologia consiste na identificação das unidades a serem classificadas por ordem de prioridade, o levantamento das informações físicas, de ocupação e as informações de consumo das unidades, com a aplicação dos indicadores energéticos, 
gerando uma lista de prioridade para cada indicador utilizado e, de posse das listas, gerar a classificação geral por prioridades com uma lista final.

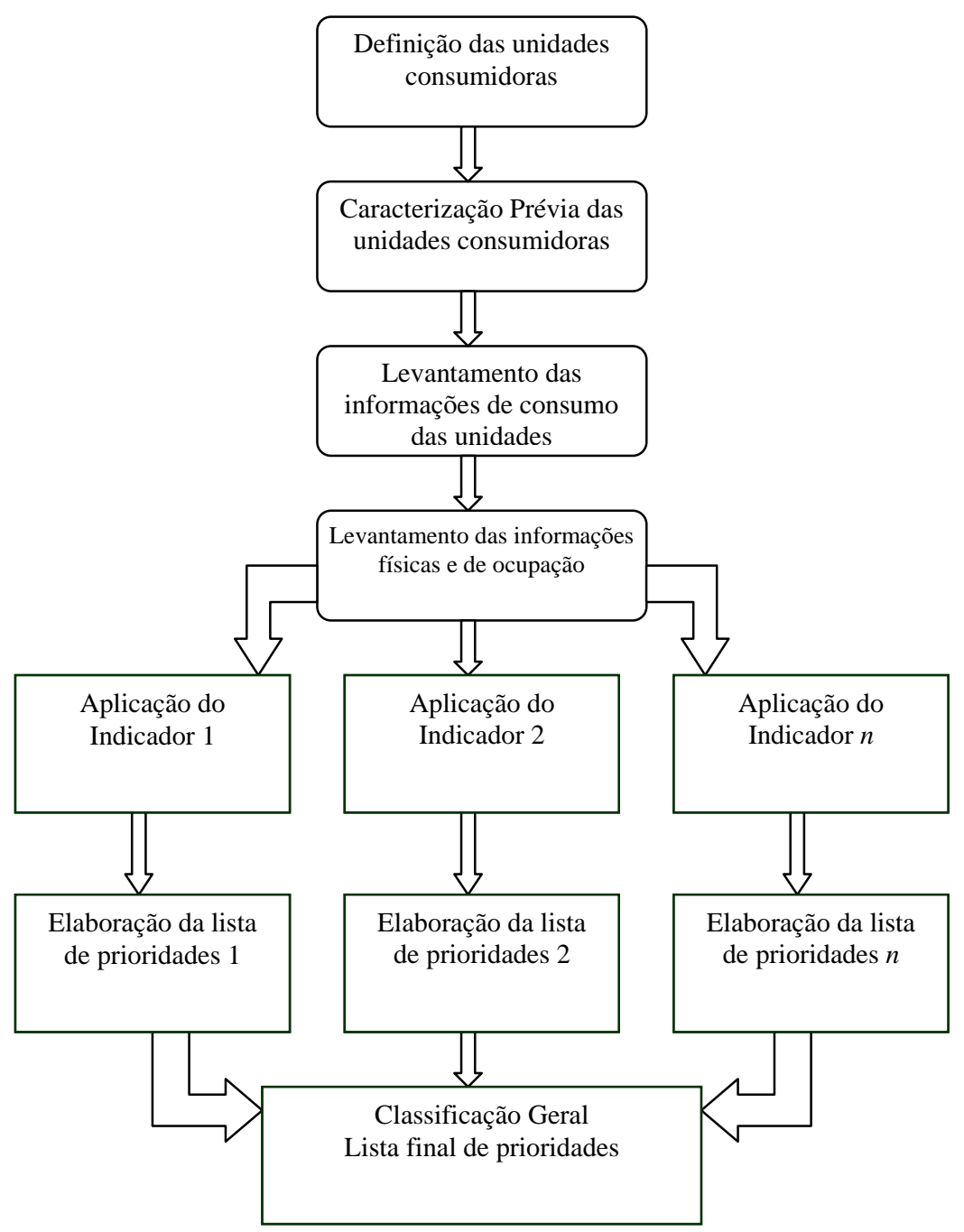

FIGURA 1: FLUXOGRAMA DE APLICAÇÃO DA METODOLOGIA PROPOSTA

\subsection{Caracterização das Unidades por Indicadores Globais}

O conhecimento das informações iniciais que caracterizam as unidades por suas atividades aliadas à aplicação dos indicadores globais no histórico de consumo, poderá identificar eventuais problemas nas instalações e os períodos de maior consumo, levando em consideração a sazonalidade dos períodos. 
Os números obtidos com a aplicação dos indicadores serão base para correções de fator de potência, ajustamento de contratos e atuação interna, para desagregar o consumo em seus usos finais e detectar quais equipamentos são utilizados em cada período.

A verificação do indicador Fator de Potência nos períodos analisados, evitará gastos desnecessários com penalidades nas faturas de energia elétrica por ultrapassagens de energia reativa, pois será base de estudo para correção deste fator (quando for o caso).

A análise do indicador Fator de Carga nos períodos analisados, poderá servir de base para caracterizar o comportamento no uso da energia, possibilitar estudos para ações de conscientização e modificações nos hábitos de utilização dos usuários, além de fornecer subsídios para o ajustamento dos contratos de energia, levando em consideração as demandas contratadas e eventualmente, solicitando as vantagens de unidade com características de sazonalidade previstas em resolução do órgão regulador (ANEEL, 2000).

O indicador PCR caracteriza a unidade por seu consumo no Período Reservado $^{5}$, em relação ao consumo total da unidade. Os números obtidos com a aplicação deste indicador classificam as unidades com prioridades de atuação, no

5 “... período de 6 horas consecutivas, compreendido, a critério da concessionária, entre $23 \mathrm{~h}$ e 30 min e 06h e 30 min, apenas os fatores de potência " $\mathrm{ft}$ " inferiores a 0,92 capacitivo, verificados em cada intervalo de 1 (uma) hora..." (ANEEL, 2000). 
intuito de identificar equipamentos que permanecem em funcionamento nos períodos de baixa atividade nas instalações. Podem ser utilizados na comparação de unidades com características semelhantes e na orientação dos usuários, com relação a mudanças nos hábitos de consumo de energia, visando a eficiência energética.

Com a aplicação dos indicadores globais as prioridades de atuação são definidas de acordo com as necessidades, seguindo os seguintes critérios:

- Correção de Fator de Potência: As unidades que apresentarem valores abaixo do mínimo exigido, de acordo com as resoluções do órgão regulador, deverão ter maior prioridade, pois a correção deste fator evitará gastos desnecessários no uso da eletricidade. Neste caso, a classificação deverá ser em ordem decrescente, iniciando com as unidades de maior consumo no período.

- PCR: Após a classificação por fator de potência, a prioridade de atuação deverá ser por aquelas unidades que apresentarem os maiores valores de consumo no período reservado, pois com ações simples de verificação das instalações, pode-se evitar o consumo desnecessário nos períodos de baixa atividade humana nas instalações.

- Fator de Carga: A atuação pelo Fator de Carga exige uma análise mais detalhada dos períodos em verificação, exigindo, em alguns casos, uma quantidade maior de períodos para caracterização, com relação a sazonalidade. 
Esta classificação das unidades, por prioridade de atuação, é importante para orientar a equipe de gestão e administração, nos casos de investimentos, visando a melhor relação entre custo e benefício e será utilizada na caracterização por indicadores específicos.

\subsection{Caracterização de Unidades por Indicadores Específicos}

Para caracterizar as unidades a partir dos indicadores específicos, as informações iniciais de características físicas, de ocupação, horários de funcionamento e principais usos finais, são essenciais. Assim como os indicadores globais, os específicos consideram as particularidades de cada unidade e os resultados serão próximos da realidade, tanto quanto forem detalhadas as informações iniciais.

Inicialmente, pode-se caracterizar a unidade utilizando os indicadores por área de utilização, com as informações de consumo e área edificada, ou seja, os números mostrarão o consumo por $\mathrm{m}^{2}$, que são utilizados para priorizar as atuações e comparar unidades com características semelhantes, de acordo com o questionário de cadastro. Este indicador poderá ser detalhado por área especifica, como por exemplo, departamentos, setores, regiões e outros, desde que se conheça a parcela de consumo e a área das instalações.

O indicador por usuário da energia pode proporcionar grandes resultados, no que diz respeito à caracterização do comportamento no uso da energia, no entanto, existe uma grande dificuldade de estimar a permanência dos usuários nas dependências de determinadas instalações, na maioria das unidades, ou seja, a variação constante dos usuários pode ocultar informações importantes para a gestão 
da energia. Porém, para efeito de comparação de unidades com usuários com características semelhantes, este indicador pode ser referência para o controle, e assim, deve ser levado em consideração na classificação das prioridades de atuação.

A análise dos usos finais utilizados é de grande importância para avaliar o desempenho e a eficiência das tecnologias utilizadas nos equipamentos. A comparação dos equipamentos utilizados com os de tecnologias mais recentes, subsidia os projetos de substituição e manutenção corretiva, prevendo a melhora na eficiência energética. No entanto, para obter números coerentes, que auxiliem as ações de eficientização, as informações sobre os usos finais devem ser detalhadas no questionário de cadastro. A seguir, alguns dos principais usos finais são considerados na classificação de unidades por prioridades de atuação.

\subsubsection{Indicador por uso da iluminação}

A iluminação com uso da energia elétrica está presente em praticamente todas as unidades consumidoras. "É responsável por, aproximadamente, 23\% do consumo de energia elétrica no setor residencial, $44 \%$ no setor comercial e serviços públicos e 1\% no setor industrial.", (ELETROBRÁS/PROCEL, 2001, p. 167).

Sendo um dos principais usos finais nas residências, comércio e serviços públicos e, responsável por uma parcela considerável do consumo de energia elétrica no País, a iluminação e seus equipamentos merecem atenção especial e devem ser utilizados de maneira eficiente para evitar desperdícios. Este uso final, em muitas unidades consumidoras, possui um potencial de economia de energia elétrica considerável, pois equipamentos com tecnologias consideradas "não eficientes" ainda 
são muito utilizados, os hábitos no uso não são eficientes e os procedimentos de manutenção não consideram a manutenção preventiva e substituição por equipamentos adequados.

Embora possua grandes potenciais de economia de energia, estimar o consumo do uso final com iluminação, desagregando do consumo dos demais utilizados em uma instalação, não é simples e, por isso, tais potenciais não são amplamente explorados. Alguns métodos são utilizados para desagregar o consumo em sistemas de iluminação e, na maioria dos casos, existe a necessidade de realizar levantamento nas unidades, verificando a quantidade e tipo de iluminação utilizada. Com o resultado do levantamento, é possível estimar o consumo associando com os horários de funcionamento dos ambientes e a potência nominal dos equipamentos.

A estimativa de consumo desagregado pode carregar uma parcela de erro considerável, na maior parte das unidades. Para obter valores muito próximos dos reais, seria necessária uma medição nos principais pontos de consumo, para verificar o comportamento dos usuários com relação à iluminação e assim projetar nas demais dependências, ou ainda, uma medição em cada ponto de alimentação dos sistemas, o que é praticamente impossível, do ponto de vista físico e econômico.

Sendo assim, geralmente opta-se por utilizar as metodologias que consideram um determinado erro na estimativa, como por exemplo, a de realizar levantamento da quantidade e tipo de iluminação.

Após desagregar o consumo é possível utilizar-se do indicador por uso final, item 2.4.3, para verificar a eficiência do sistema, comparando-se com unidades 
semelhantes com equipamentos e hábitos de uso mais eficientes. Sendo assim, podem-se relacionar o consumo de energia nos sistemas de iluminação a qualquer outra variável possível, tomando como exemplo, a área edificada, número de usuários, produção e outros. A escolha da melhor variável dependerá das características da unidade e os critérios para priorizar as ações de eficiência, deverão ser estabelecidos pelo gestor ou equipe de gestão da energia.

Uma alternativa para estabelecer prioridades por este uso final é comparar a eficiência da tecnologia utilizada, com as de tecnologias mais recentes. Esta comparação identificará possíveis potenciais de redução com a substituição ou manutenção do sistema atual.

Para estimar o consumo da nova tecnologia dos sistemas de iluminação, necessita-se de aplicar a metodologia de consumo desagregado e, as unidades deverão ser priorizadas de forma decrescente, de acordo com o potencial apresentado na comparação das tecnologias.

\subsubsection{Indicador por uso de sistemas de Ar-Condicionado e refrigeração}

Ar Condicionado, segundo a definição técnica de aplicação, é o processo de tratamento de ar destinado a controlar simultaneamente a temperatura, a umidade, a pureza e a distribuição de ar de um meio ambiente (ELETROBRÁS/PROCEL, 2001, p. 274).

Estes ambientes podem ser destinados tanto ao conforto humano ou animal, neste caso os sistemas aplicados são vulgarmente chamados de ar condicionado de 
conforto, ou em ambientes destinados ao desenvolvimento de determinados processos industriais ou laboratoriais, e neste caso, o sistema passa a ser chamado por sistema de ar condicionado de processo.

Segundo diferentes levantamentos estatísticos, o consumo de energia no Brasil envolve um consumo de energia elétrica distribuído da seguinte forma: $46.9 \%$ pela indústria, $22.3 \%$ pelo setor residencial, 14,1\% pelo setor comercial e 8,69\% pelo setor público. Dentro do setor residencial o maior vilão de energia elétrica são aparelhos de refrigeração e ar condicionado, que representam 33\% do consumo desse setor. Uma redução de apenas $1 \%$ do consumo dos equipamentos de refrigeração residenciais, representaria uma economia de cerca de $30 \mathrm{GWh} / a n$. Já no setor comercial, $20 \%$ do consumo de energia elétrica se devem aos aparelhos de ar condicionado (central e de janela). Apenas através desses dois setores pode ser visto que $10,17 \%$ do consumo de energia elétrica total do país se deve a aplicações de ar condicionado e refrigeração nas quais o componente mais importante, do ponto de vista da conversão de energia em um ciclo de refrigeração, é o compressor $\left(\operatorname{LaAR}^{6}, 2006\right)$.

Por representar grande parte do consumo de energia elétrica, os equipamentos de refrigeração e ar condicionado são importantes no processo de gestão da energia elétrica.

6 Laboratorio de Ar-condicionado e Refrigeração - Universidade de Brasília - Faculdade de Tecnologia Departamento de Engenharia Mecânica http://www.laar.unb.br/saibamais_compressores.htm Acesso 05/2006. 
Para explorar os potenciais de economia de energia elétrica nos sistemas de refrigeração e ar condicionado e, verificar a eficiência dos sistemas utilizando-se dos indicadores de consumo é necessário desagregar o consumo desses equipamentos dos demais utilizados nas unidades.

Os equipamentos de refrigeração utilizados em processos industriais, e os equipamentos utilizados para a climatização de ambientes, para proporcionar conforto térmico, possuem características específicas e, uma das alternativas para desagregar o consumo destes equipamentos, utiliza-se das informações de potência em $\mathrm{TR}^{7} \mathrm{e}$ seus coeficientes de eficiência $\left(E E R^{8}\right)$ e performance $\left(C O P^{9}\right)$. Além das informações técnicas, outros parâmetros como as características arquitetônicas, a carga térmica, a temperatura ambiente e a área climatizada, que influenciam diretamente no consumo dos equipamentos, são essenciais.

As características de arquitetura influenciam o consumo, pois o tipo de paredes, forro, janelas e orientação solar, sofrem influência das variações de temperatura, aumentando assim a carga térmica e conseqüentemente o consumo de energia elétrica no condicionamento do ambiente. Outras características podem influenciar no aumento da carga térmica, como por exemplo, o tipo de iluminação utilizada.

\footnotetext{
${ }^{7} \mathrm{TR}=$ Tonelada de Refrigeração

${ }^{8}$ EER $=$ Energy Efficiency Rate (Razão de Eficiencia Energética) - expresso em BTU/h / Watts (PROCEL, 2002).

${ }^{9} \mathrm{COP}=$ Coefficient of Performance: Medido em Watts de capacidade de refrigeração por Watt elétrico consumido (Lee, A. S.; et. al., 2001).
} 
Vários estudos foram realizados com o intuito de estimar o consumo e demanda de equipamentos de refrigeração e condicionamento de ambientes, como em BENNAKHI e MAHMOUD (2004), que utilizaram redes neurais nesta estimativa, a partir da caracterização dos ambientes estudados e informações de temperatura ambiente e, WESTPHAL e LAMBERTS (2003) que utilizam parâmetros climáticos, como temperatura mínima e máxima em um período, para analisar o comportamento da carga térmica de ambientes climatizados.

A variação de eficiência energética dentre os tipos de tecnologias existentes é outra questão que deve ser levada em consideração no momento da escolha e aquisição, tanto para projetos novos, quanto para retrofit do sistema. Esta variação é considerada em LEE et. al. (2001), que utiliza uma ferramenta computacional para auxiliar na simulação de comparação de conceitos de eficiência energética aplicados em 2 (dois) novos edifícios, com as demais unidades. Neste trabalho é realizado um levantamento de potências dos equipamentos de ar condicionado e, com este levantamento estimou-se o consumo para a posterior comparação com as demais tecnologias.

Outros tipos de ferramentas que auxiliam no processo de desagregar o consumo de energia elétrica com este tipo de sistema são aquelas que comparam as informações de temperatura ambiente, com o histórico de consumo das unidades. SAIDEL et. al. (2006) descreve uma metodologia, aplicada em uma ferramenta computacional, que utiliza as informações históricas da curva de carga de uma determinada unidade para prever a demanda nos períodos para os próximos dias. Os resultados obtidos, na relação da temperatura média diária com o consumo diário, 
mostraram que existe uma variação grande no consumo e demanda da unidade a partir de uma determinada temperatura e que pode ser associado ao consumo de energia elétrica nos sistema de refrigeração e ar condicionado.

De forma análoga à iluminação, após desagregar o consumo é possível utilizarse do indicador por uso final, item 2.4.3, para verificar a eficiência do sistema, relacionando o consumo de energia elétrica, a qualquer outra variável possível, tomando como exemplo, a área edificada, usuários, produção e outros. Da mesma forma, a escolha da melhor variável dependerá das características da unidade e, os critérios para priorizar as ações de eficiência, deverão ser estabelecidos pelo gestor ou equipe de gestão da energia.

A comparação do sistema atualmente utilizado com outros de tecnologia mais eficiente poderá ser uma alternativa para estabelecer prioridades no plano de ações de eficiência energética.

\subsubsection{Indicador por uso de equipamentos de Informática}

O uso de computadores e periféricos (impressoras, digitalizadores e outros) cresceu muito nas ultimas décadas. Este crescimento fez com que a parcela de consumo de energia elétrica com estes equipamentos aumentasse significativamente.

Impulsionados pelo acesso cada vez maior das pessoas à internet e pela informatização das empresas e escritórios, o seguimento dos equipamentos de informática traz consigo um aumento significativo no consumo de energia elétrica, seja pelo número de microcomputadores instalados e dos periféricos a eles associados, seja pelo aumento 
gerado no consumo dessas máquinas, causado por sua maior capacidade de processamento (SANTOS et. al., 2004)

Sendo assim, as ações de eficiência energética neste tipo de uso final devem ser consideradas nos processos de gestão do uso e hábitos de consumo dos usuários. Ações simples podem proporcionar grandes resultados, como por exemplo, a utilização do programa Energy Saver, que reduz automaticamente a energia consumida pelos equipamentos de escritório que, apesar de ligados, ficam inativos quando em ociosidade. A tabela 1 mostra o potencial de conservação nos diversos equipamentos de escritório.

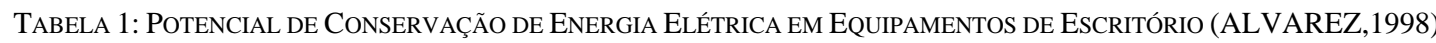

\begin{tabular}{|c|c|}
\hline Equipamentos & Potencial de conservação (\%) \\
\hline Microcomputador & 80 \\
\hline Impressora & 65 \\
\hline Fotocopiadora & 60 \\
\hline Fax & 50 \\
\hline
\end{tabular}

O processo para desagregar o consumo dos equipamentos de escritório dos demais utilizados nas unidades, conta com o levantamento da quantidade de equipamentos e horários de utilização.

A quantidade de equipamentos existentes pode ser facilmente obtida nos departamentos de controle de patrimônio das instituições e o levantamento dos horários de funcionamento e utilização podem ser obtidos através de entrevistas com os usuários ou responsáveis pelas unidades. 
Com a potência média dos equipamentos e informações de uso, é possível estimar o consumo com estes usos finais. A tabela 2 contém a potência de alguns equipamentos e a estimativa de economia com a utilização do programa Energy Saver.

TABela 2: ECONOMia de ENERgia em Computadores com o ENERgy SAVER ACIONAdo (SANTOS, 2004)

\begin{tabular}{|c|c|c|c|}
\hline Modelo & $\begin{array}{c}\text { Operação } \\
\text { Normal } \\
\text { [W] }\end{array}$ & $\begin{array}{c}\text { Energy Saver } \\
\text { Acionado 10, } \\
\text { [W] }\end{array}$ & $\begin{array}{c}\text { Economia de } \\
\text { Energia [\%] }\end{array}$ \\
\hline $\begin{array}{c}\text { Pentium III 866 } \\
\text { Monitor 17" }\end{array}$ & 123 & 71 & 42,2 \\
\hline $\begin{array}{c}\text { AMD - 450 } \\
\text { Monitor 15" }\end{array}$ & 108 & 51 & 52,7 \\
\hline $\begin{array}{c}\text { Pentium III 733 } \\
\text { Monitor 17" }\end{array}$ & 108 & 48 & 55,5 \\
\hline $\begin{array}{c}\text { Pentium III 600 } \\
\text { Monitor 15" }\end{array}$ & 93 & 39 & 58,1 \\
\hline $\begin{array}{c}\text { Pentium III 700 } \\
\text { Monitor 15" }\end{array}$ & 110 & 51 & 53,5 \\
\hline
\end{tabular}

Após estimar o consumo dos equipamentos de informática é possível verificar a eficiência na utilização com esses equipamentos através do indicador por uso final, item 2.4.3, relacionando com a quantidade de usuários dos equipamentos. Este indicador além de fazer parte do critério de priorização das ações de eficiência, poderá ser parâmetro para avaliação do aumento ou substituição de máquinas. Esta avaliação deverá ser realizada pela administração e as questões de prioridade na caracterização das unidades, pelo gestor ou equipe de gestão.

\footnotetext{
${ }^{10}$ Apenas com o desligamento do monitor.
} 


\subsubsection{Indicador por utilização de outros equipamentos}

A aplicação dos indicadores energéticos nos demais usos finais dependerá das características de utilização das unidades. Dentre os equipamentos mais utilizados, podem-se citar os motores elétricos, que têm grande influência no consumo nos setores industriais, equipamentos de aquecimento de água, muito utilizados em hospitais, residências e escolas, aquecimento de ambientes, utilizados em algumas regiões e países com temperaturas baixas e em criadouros de animais.

Todos os conceitos de aplicação dos indicadores e processos para desagregar o consumo poderão ser aplicados aos demais usos finais, considerados importantes no processo de gestão da energia elétrica.

\subsection{Avaliação e Atuação com Base na Lista de Prioridades}

As ações para tornar as instalações mais eficientes do ponto de vista do uso da eletricidade deverão ser baseadas na caracterização elaborada a partir dos resultados da aplicação dos indicadores. Para cada um dos indicadores aplicados, deverá ser elaborada uma lista classificando as unidades por ordem de prioridade baseando-se nos números obtidos.

Baseando-se nas listas de prioridades de todos os indicadores, deverão ser identificadas as unidades com maior incidência, sendo assim, as cinco primeiras unidades de cada uma das listas devem ser relacionadas, criando a lista de prioridades final geral. 
Após a elaboração da lista final, estudos deverão ser realizados para detectar as ações de retorno imediato e baixo custo de implantação e, as ações de conscientização e orientação do uso eficiente da energia elétrica deverão ser priorizadas e iniciadas com a maior brevidade, em todas as unidades, iniciando por aquelas com maiores potenciais.

As ações de retrofit dos sistemas de iluminação, refrigeração e ar condicionado, deverão passar por um estudo mais detalhado, com o intuito de levantar custos e analisar o retorno dos investimentos aplicados.

A avaliação dos gestores ou equipe de gestão é essencial e poderá alterar a ordem da lista, de acordo com as avaliações de retorno financeiro, as urgências das unidades verificadas e a experiência dos gestores.

Todo o processo de utilização dos indicadores de consumo no auxílio à gestão de energia deverá ser constantemente atualizado pelos gestores, pois a manutenção e boa avaliação dos números obtidos evitarão os erros na distribuição dos recursos e possivelmente, proporcionará bons resultados. 


\section{O EXEMPLO DE GESTÃo NA UNIVERSIDADE DE SÃO PAULO}

Criada em 1934, a Universidade de São Paulo possui instalações que se estendem por 20 municípios do Estado de São Paulo. Suas maiores instalações estão na Capital, São Carlos, Ribeirão Preto, Piracicaba, Pirassununga e Bauru. Além destas, a USP mantêm instalações em mais 14 cidades distribuídas no litoral e interior de São Paulo.

Com uma área de aproximadamente 76,5 milhões de metros quadrados, possui um total de área construída de 1.601,2 mil m². Fizeram uso destas instalações 84.158 alunos, 5.222 docentes e 15.289 funcionários, segundo informações de 2005 (USP, 2006).

A energia elétrica faz parte de todas as atividades desenvolvidas nestas instalações e constitui infra-estrutura imprescindível em muitas delas.

\subsection{O Consumo de energia na USP}

A Universidade de São Paulo possui mais de 300 faturas de energia, distribuídas na capital, litoral e interior de São Paulo, conforme tabela 3. 
TABELA 3: DistRIBUiÇÃo DE FATURAS POR CIDADE/CAMPUS (SAIDEL, 2005)

\begin{tabular}{|l|cc|}
\hline \multicolumn{1}{|c|}{ Campus } & Número de Unidades Consumidoras \\
\hline & Grupo A & Grupo B \\
\hline São Paulo & 13 & 14 \\
\hline Ribeirão Preto & 30 & 75 \\
\hline Piracicaba & 38 & 118 \\
\hline São Carlos & 5 & 4 \\
\hline Bauru & 2 & 5 \\
\hline Pirassununga & 1 & 0 \\
\hline outras cidades & 6 & 15 \\
\hline & & 231 \\
\hline Total & 95 & \\
\hline
\end{tabular}

Todas essas unidades alcançaram em 2004 um consumo de 110GWh, com uma demanda máxima de potência de cerca de 31,7 MW, com custos mensais superiores a $\mathrm{R} \$ 2.000 .000,00$ (SAIDEL, 2005).

A partir dos números ligados à utilização da eletricidade na USP, fica evidente a importância de uma boa gestão do uso da energia. Devido à dimensão das instalações e a grande diversidade de atividades realizadas, as ações de eficiência, do ponto de vista tecnológico e orientação de usuários para que utilizem a energia elétrica de forma consciente, possuem custo muito elevado e exigem a atuação constante de profissionais especializados na área.

Dentre todas as unidades, a CUASO (Cidade Universitária Armando de Sales Oliveira), localizada na capital, é a maior do ponto de vista de consumo de energia, contribuindo com aproximadamente $58 \%$ do consumo total da USP, com demanda máxima superior a $16 \mathrm{MW}$ e um total de mais de 55\% dos custos com a energia, conforme gráfico da figura 1. 

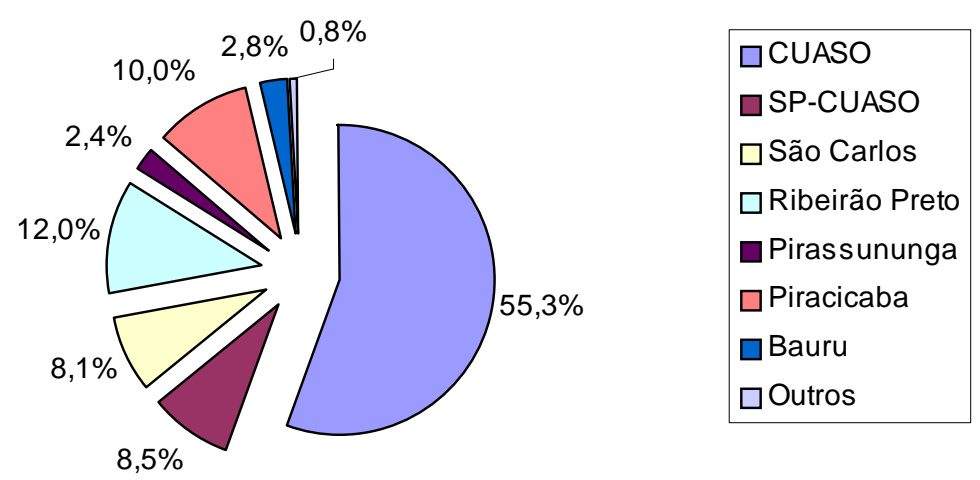

FIGURA 2: PARTICIPAÇÃO DOS CAMPI NO DISPÊNDIO COM ELETRICIDADE, 2004 (SAIDEL, 2005)

Atendida em tensão de sub-transmissão no sub-grupo $A 2^{11}$, possui uma única fatura, com a distribuição para suas diversas unidades alocadas na CUASO, realizada por rede de atendimento própria. Neste caso, a dificuldade da gestão se torna ainda maior, pois as informações das faturas de energia, posicionam os gestores sobre as condições da unidade. Sendo assim, para realizar a gestão individual das unidades, é necessária uma ferramenta que forneça informações semelhantes às da concessionária.

\subsection{A gestão da energia na USP}

Um bom exemplo de gestão é a Universidade de São Paulo, que possui um programa de gestão de energia denominado pureusp (Programa para o Uso Eficiente de Energia na USP), ligado à COESF (Coordenadoria do Espaço Físico da USP). Desde 1997, o pureusp tem promovido ações para alcançar a eficiência nas

\footnotetext{
${ }^{11}$ Sub-grupo A2: Consumidores atendidos em tensões entre 88 kV e 138 kV.
} 
instalações da Universidade, estas ações vão desde elaboração de projetos para substituição de equipamentos obsoletos, com baixa eficiência, à orientação dos usuários de como utilizar a energia elétrica eficientemente.

A descrição detalhada de toda a história, ações e resultados da experiência da USP com a gestão da energia são apresentados em (SAIDEL, 2005).

\subsection{Ferramentas Utilizadas}

No intuito de conhecer suas instalações e como é utilizada a energia elétrica, a Universidade de São Paulo desenvolveu ferramentas que registram as informações de perfil de consumo das unidades e das faturas de energia elétrica, para fornecer subsídios para a criação dos planos de ação, no que diz respeito à eficiência energética em suas instalações. As principais são o Contaluz Web, sistema de gestão de faturas e o SISGEN, sistema de gerenciamento de consumo de energia elétrica.

\subsubsection{Contaluz web}

O CONTALUZ Web é um sistema de gerenciamento de faturas de energia elétrica que armazena as informações das faturas emitidas pelas concessionárias, permissionárias ou comercializadoras de energia, elaborando relatórios, gráficos e outros recursos. Seu objetivo é a redução de custos das unidades cadastradas no sistema, através do controle de prazos de pagamento, multas e eventuais cobranças indevidas.

O sistema visa o bom conhecimento das principais informações de contratos e faturas de energia, que é essencial para realizar uma boa gestão energética. Desta 
maneira, o CONTALUZ reúne em banco de dados, com interface via Web, todas as informações de faturas de energia elétrica. Destinado à gestão corporativa de faturas de energia, o CONTALUZ encontra-se implantado na Universidade de São Paulo desde 1998, armazenando as informações de todas as 326 unidades consumidoras dos diversos campi.

A operação do sistema conta com a participação dos responsáveis dos departamentos e unidades dos diversos campi da Universidade, os quais todos os meses incluem as informações das faturas de energia, das quais são responsáveis, enviando uma cópia aos gestores do PURE USP. A figura 2 apresenta um exemplo de tela para a inserção das informações da fatura de energia no sistema.

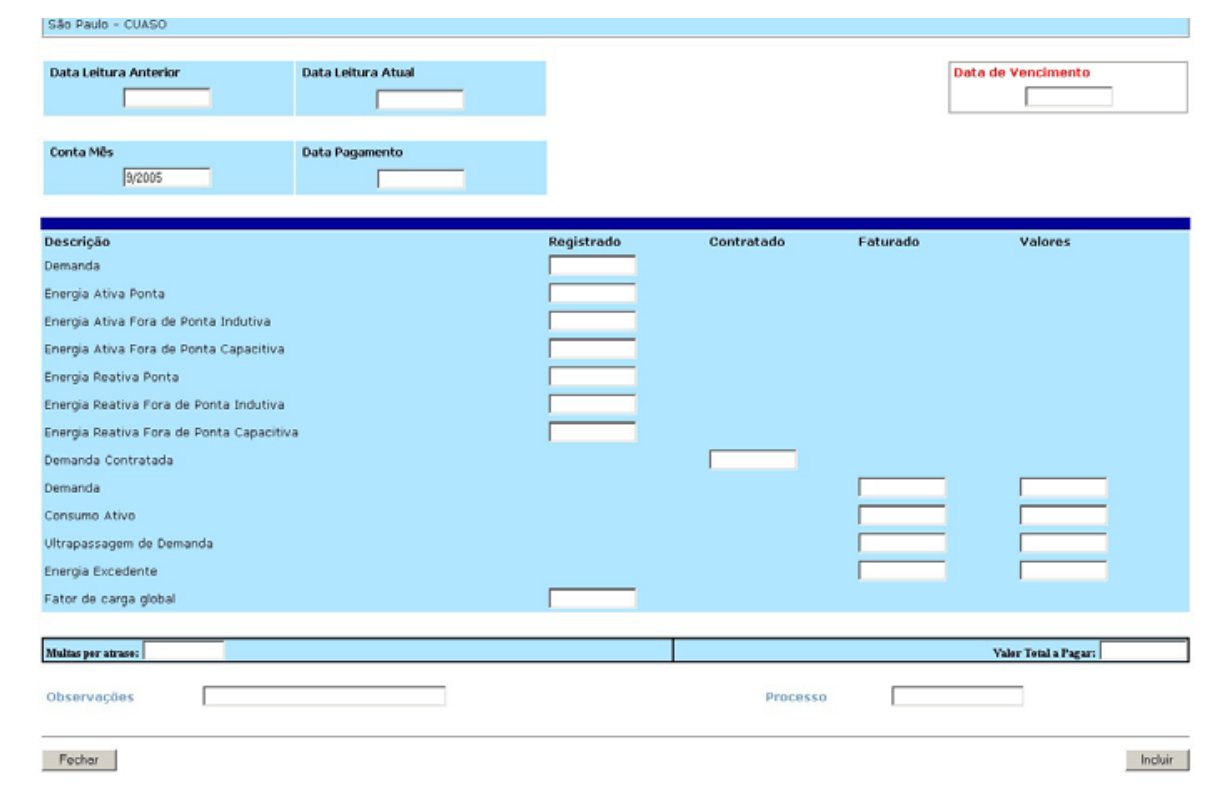

FiguRA 3 - TELA DE INCLUSÃo DAS INFORMAÇÕES DAS FATURAS DE ENERGIA (A4 - CONVENCIONAL).

Após a inclusão das informações, os gestores do PURE realizam a validação das faturas e utilizam as informações através de relatórios, para atuar de forma corretiva e preventiva em todas as unidades consumidoras. 


\subsubsection{Sisgen}

O SISGEN é um sistema de informação autônomo para suporte à gestão de energia e de contratos de fornecimento, voltado para empresas e instituições interessadas em conhecer melhor o seu perfil de consumo de energia e atuar de forma a racionalizar esse consumo e reduzir despesas, atendendo as expectativas dos consumidores cativos de médio e grande porte, consumidores livres e concessionárias de energia.

Trata-se de um sistema que visa a gestão corporativa da energia elétrica, na medida em que permite o monitoramento remoto de múltiplas unidades de consumo e independe dos usuários para a realização de suas principais funções, como a coleta e armazenamento de dados, acompanhamento das grandezas elétricas envolvidas, emissão de alarmes e relatórios.

O SISGEN conta com um programa de monitoração que permite o acompanhamento e tratamento, em terminal remoto, de diversas grandezas (energia ativa e reativa, demanda, fator de potência, tensão e corrente), que caracterizam o uso da energia elétrica. Adicionalmente, conta com programas responsáveis pela aquisição automática de dados e acompanhamento das grandezas medidas.

A figura 3 apresenta uma tela do SISGEN, expressando uma curva diária de uma unidade consumidora. 


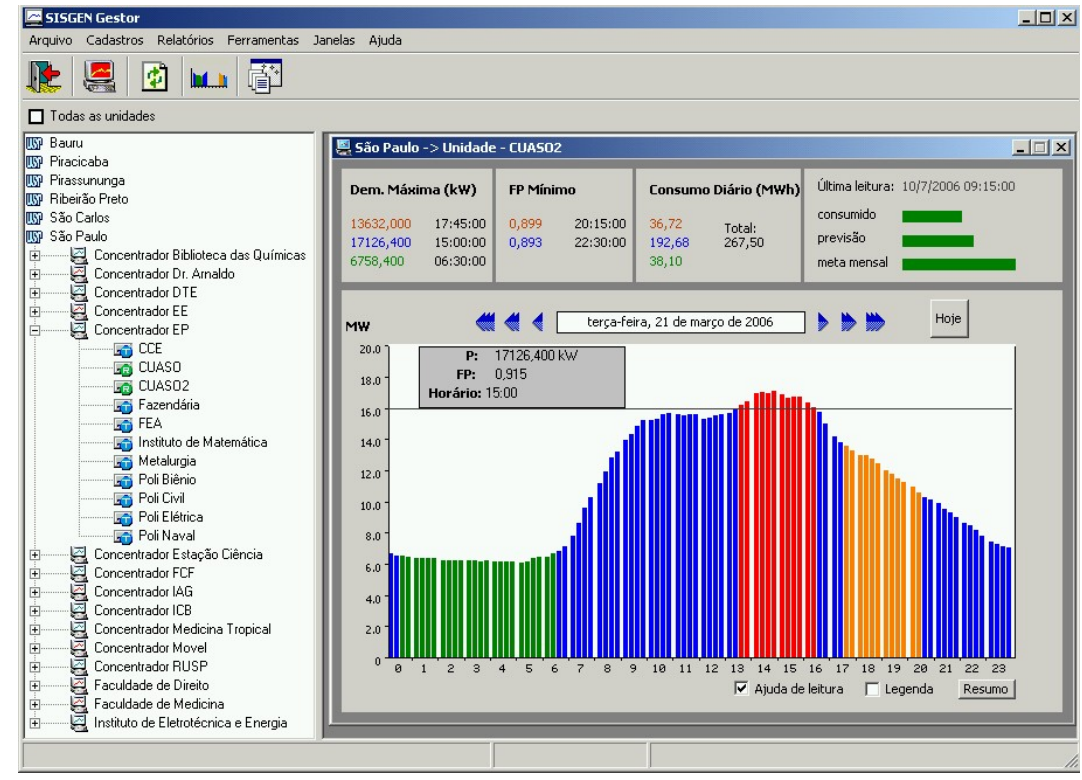

FIGURA 4 - GRÁFICO DA CURVA DE CARGA DIÁRIA DE UMA UNIDADE CONSUMIDORA.

\subsection{Principais Usos Finais}

Um estudo realizado em 1996 na CUASO, descrito com detalhes em SAIDEL, 2005, apresentou o consumo desagregado conforme a figura 4.

Os valores obtidos mostraram-se coerentes com a expectativa, a análise qualitativa e as pesquisas de hábito e uso apontavam a forte participação dos usos finais iluminação e ar condicionado no consumo de energia do tipo de edificação e atividade presente na CUASO. A parcela correspondente à iluminação pública está considerada na parcela equipamentos, e foi estimada em 7\%. Estudos posteriores permitiram avaliar que $2 \%$ do consumo correspondiam a microcomputadores, restando aos diversos equipamentos, de uso variado nas instalações, 42\% (SAIDEL, 2005). 

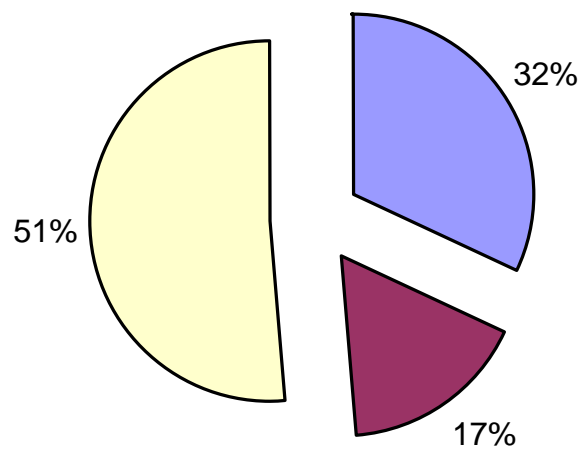

口lluminação

Ar-condicionado

$\square$ Equipamento e

microcomputadores

FiguRA 5: CONSUMO DESAGREgAdO CUASO, 1996 (SAIDEL, 2005)

\subsubsection{Iluminação}

O sistema de iluminação é um dos principais consumos da universidade, representando cerca de $32 \%$ do consumo total da CUASO. Desta maneira, foi realizado um levantamento para verificar quais as tecnologias utilizadas nos sistemas de iluminação. As informações foram extraídas do Projeto CONSERVUSP, detalhadas em SAIDEL, 2005.

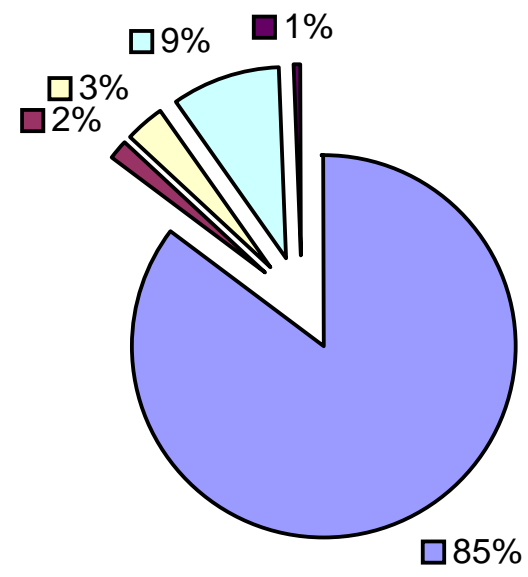

$\square$ Fluorescente

$\square$ Incandescente

$\square$ Mista

$\square$ Vapor Metálico

口Vapor de Sódio

FiguRA 6: TECNOLOGIA DE ILUMINAÇÃo UTILIZADA (SAIDEL, 2005) 
Sendo a maior participação de lâmpadas fluorescentes, foi realizada ainda, uma segmentação, e pode ser verificada na Figura 7. As lâmpadas fluorescentes compactas eram insignificantes e por esta razão foi excluída dessa representação (SAIDEL, 2005).
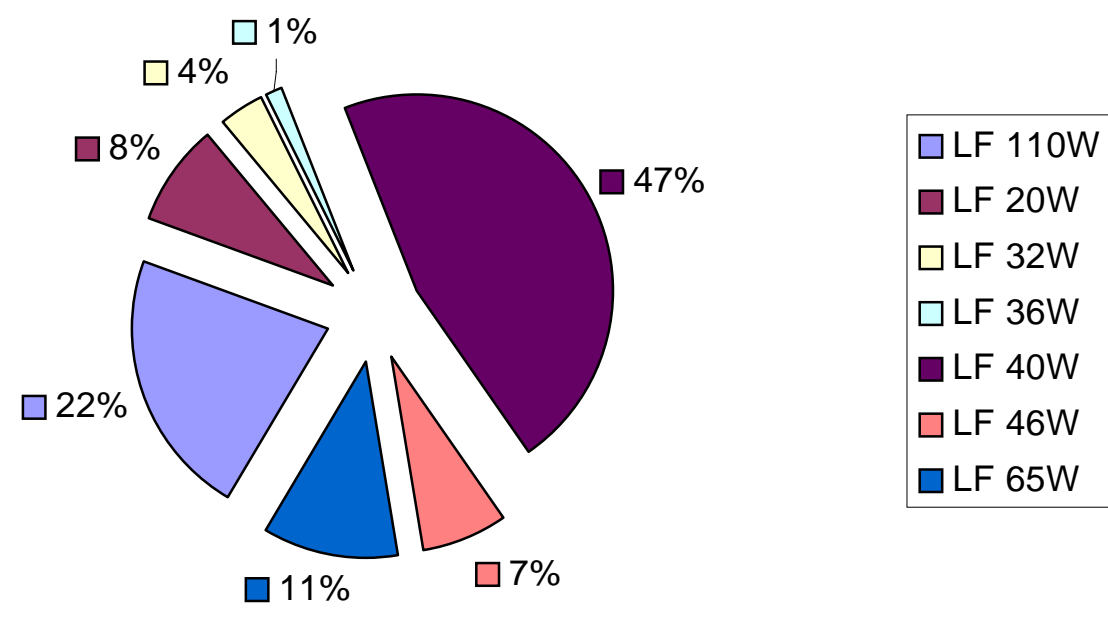

FIGURA 7: ESTRATIFICAÇÃo DA TECNOLOGIA DE ILUMINAÇÃO FLUORESCENTE (SAIDEL, 2005)

\subsubsection{Ar-condicionado}

Levando em consideração as informações extraídas da figura 5, o consumo dos equipamentos de ar condicionado, corresponde à parcela de $17 \%$ do consumo total do Campus.

No entanto, a parcela atribuída ao uso final ar condicionado é tímida frente à participação desse uso final no consumo atual. Atualmente, o comportamento do consumo e da demanda de potência é condicionado pela temperatura ambiente, em função do aumento expressivo da utilização de equipamentos de ar condicionado (SAIDEL, 2005). 
Alguns trabalhos recentes foram realizados no intuito de estimar o consumo dos sistemas de ar condicionado em algumas unidades. O projeto FINEP-Purefa ${ }^{12}$, tem como um de seus objetivos, verificar a eficiência dos sistemas utilizados em algumas unidades, comparando as tecnologias utilizadas e equipamentos antigos, frente as novas tecnologias, analisando a viabilidade técnica e econômica, para a substituição dos mesmos.

Em SAIDEL et. al. (2006) trabalho que descreve uma metodologia, aplicada em uma ferramenta capaz de estimar a curva de carga das unidades, baseados em dados históricos e de previsão da temperatura, alguns resultados e conclusões apontam que o consumo em sistemas que variam com temperatura ambiente, são uma parcela importante no consumo total da CUASO, levando a crer que ultrapassam o percentual de $17 \%$ em 1996, indicados na figura 4.

No caso específico da unidade CUASO, verificou-se que, acima de $23^{\circ} \mathrm{C}$, cada grau de aumento na temperatura representa aumento significativo da demanda média diária, chegando, em alguns períodos, a aumentos de $400 \mathrm{~kW} /{ }^{\circ} \mathrm{C}$ (SAIDEL et. al., 2006). Exemplificando, pode-se extrair dos gráficos apresentados no trabalho, a variação do consumo em dias com temperaturas médias diferenciadas, com a variação de aproximadamente $4 \% /{ }^{\circ} \mathrm{C}$, no mês de fevereiro de 2004 .

No mês de fevereiro, pode-se observar que existe uma queda brusca da temperatura, variando de $32^{\circ} \mathrm{C}$ à $19^{\circ} \mathrm{C}$ em poucos dias, o que

\footnotetext{
${ }^{12}$ FINEP PUREFA - Programa de uso racional de energia e fontes alternativas na USP, financiado pelo Fundo de Estudos e Projetos do Ministério da Ciência e Tecnologia.
} 
provocou uma diminuição de aproximadamente $120 \mathrm{MWh}$ no consumo entre os dias 19 e 25, apresentados na figura 7 (SAIDEL et. al., 2006).

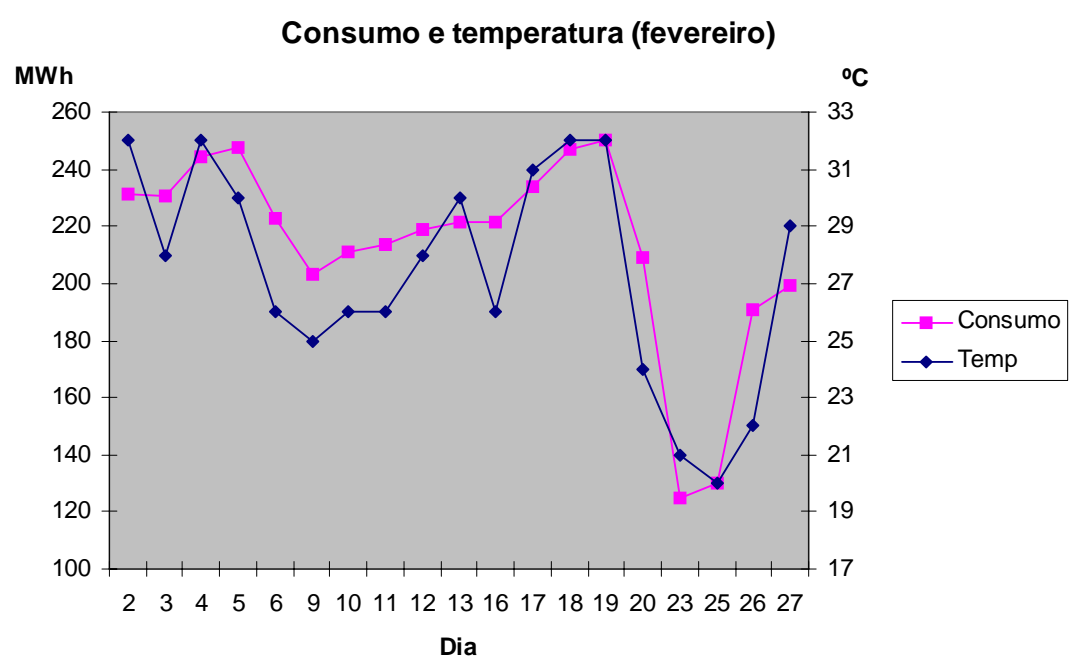

Figura 8: CONSUMO X TEMPERATURA - FEVEREIRO 2004 (SAIDEL ET. AL., 2006).

Neste caso especifico, pode-se atribuir a variação de consumo, aos equipamentos de refrigeração e climatização de ambientes no campus, que comparando estes dois dias, tiveram uma variação de aproximadamente $50 \%$ no consumo.

\subsubsection{Outros equipamentos}

A grande parcela de consumo em equipamentos, com referencia à figura 3 , leva em consideração a parcela de iluminação publica e equipamentos de escritório, estimados respectivamente, em 7\% e 2\%, em 1996 (SAIDEL, 2005).

Levando em consideração o grande crescimento de utilização de equipamentos de informática nos últimos 10 anos, pode-se afirmar que, atualmente a parcela de consumo com equipamentos de escritório, é diferente da estimada anteriormente. 


\section{APLICAÇÃO DA METODOLOGIA NA CIDADE}

UNIVERSITÁRIA ARMANDO DE SALES OLIVEIRA - CUASO.

O estudo de caso baseado nas informações de consumo de energia elétrica da CUASO, com a aplicação da metodologia de classificação de unidades consumidoras por prioridades de atuação, leva em consideração o monitoramento de consumo através da ferramenta de gestão de consumo da USP, o SISGEN.

Parte do projeto PUREFA, o SISGEN vêm sendo instalado na USP desde 1998 e monitora atualmente mais de 100 unidades consumidoras em todos os campi da universidade. Atendida em tensão de sub-transmissão no sub-grupo A2 e com distribuição para suas diversas unidades internas realizada por rede de atendimento própria, em média e baixa tensão, a CUASO é maior unidade de consumo de energia elétrica da USP e conta mais de 50 unidades monitoradas pelo SISGEN.

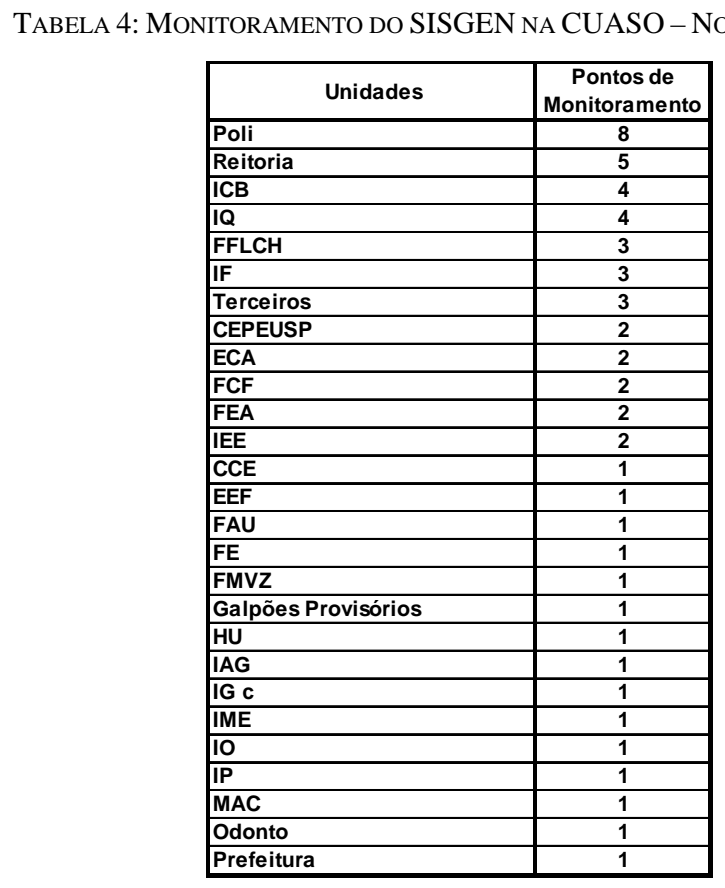


O estudo de caso considera 48 unidades consumidoras da CUASO, no período de Janeiro de 2005 a Outubro de 2006, em que, houve uma grande evolução do monitoramento de consumo de energia elétrica no campus.

TABELA 5: UNIDADES MONITORADAS CONSIDERADAS NO ESTUDO DE CASO

\begin{tabular}{|c|c|c|c|c|}
\hline Faculdade/Instituto/Unidade & \multicolumn{2}{|c|}{ Unidades Monitoradas - SISGEN } & Faculdade/Instituto/Unidade & Unidades Monitoradas - SISGEN \\
\hline \multirow{3}{*}{ Instituto de Química } & \multicolumn{2}{|c|}{ Biblioteca das Quimicas } & $\begin{array}{c}\text { Faculdade de Arquitetura e } \\
\text { Urbanismo }\end{array}$ & FAU \\
\hline & \multicolumn{2}{|c|}{ Quimica Biotério } & Faculdade de Ciencias & Farmácia 13 a 17 \\
\hline & \multicolumn{2}{|c|}{ Quimica Semi - Industrial } & Farmacêuticas & Farmácia 13A e 13B \\
\hline Centro de Computação Eletronica & \multicolumn{2}{|c|}{ CCE } & Faculdade de Economia e & FEA \\
\hline Centro de Práticas Esportivas & \multicolumn{2}{|c|}{ CEPEUSP - Quadras } & Administração & Fazendaria \\
\hline \multirow{3}{*}{$\begin{array}{l}\text { Faculdade de Filosofia, Letras, } \\
\text { Ciências Sociais e História }\end{array}$} & \multicolumn{2}{|c|}{ Ciencias Sociais e Letras } & Faculdade de Educação & Faculdade de Educação \\
\hline & \multicolumn{2}{|c|}{ FFLCH - Administração } & Hospital Universitario & Hospital Universitario / ICB III \\
\hline & \multicolumn{2}{|c|}{ História e Geografia } & \multirow{2}{*}{ Instituto de Energia e Eletrotécnica } & Energia Solar \\
\hline \multirow{2}{*}{ Escola de Comunicação e Artes } & \multicolumn{2}{|c|}{ Prédios } & & Clube dos Funcionarios \\
\hline & \multicolumn{2}{|c|}{ ECA - SINTUSP } & \multirow{3}{*}{ Instituto de Ciencias Biologicas } & ICB I \\
\hline Escola de Educação Fisica & \multicolumn{2}{|c|}{ Escola de Educação Fisica } & & ICB II \\
\hline \multirow{8}{*}{ Escola Politécnica } & \multicolumn{2}{|c|}{ Elétrica } & & ICB IV \\
\hline & \multirow{2}{*}{ Hidraulica } & Administração & \multirow{2}{*}{ Instituto de Fisica } & Tokamac/Administração \\
\hline & & Laboratórios & & Fisica/Restarurante \\
\hline & \multicolumn{2}{|c|}{ Metalurgia } & $\begin{array}{c}\text { Instituto de Matemática e } \\
\text { Estatística }\end{array}$ & IME \\
\hline & \multicolumn{2}{|c|}{ Naval } & Instituto de Geociência & Instituto de Geociência \\
\hline & \multicolumn{2}{|c|}{ Quimica } & Instituto Oceanografico & 10 \\
\hline & \multicolumn{2}{|c|}{ Civil } & $\begin{array}{c}\text { Instituto de Astronomia e } \\
\text { Geociência }\end{array}$ & IAG \\
\hline & \multicolumn{2}{|c|}{ Bienio } & Museu de Arte Contemporânea & MAC \\
\hline \multirow{4}{*}{ Reitoria } & \multicolumn{2}{|c|}{ Reitoria Nova } & Faculdade de Odontologia & Odontologia \\
\hline & \multicolumn{2}{|c|}{ Creche Central } & Prefeitura & $\mathrm{PCO}$ \\
\hline & \multirow{2}{*}{ CRUSP } & Bloco B & Instituto de Psicologia & Psicologia \\
\hline & & Bloco G & Galpões Provisórios & Galpões Provisórios \\
\hline $\begin{array}{l}\text { Faculdade de Medicina Veterinária } \\
\text { e Zootecnia } \\
\end{array}$ & \multicolumn{2}{|c|}{ Veterinária } & Terceiros & Banco Real \\
\hline
\end{tabular}

A figura 9 mostra a evolução de monitoramento do consumo da CUASO no período considerado, baseando-se apenas nas informações das unidades do estudo de caso. Para mostrar a evolução, a soma dos consumos de todas as unidades é comparada com o consumo total da CUASO, também obtido através do SISGEN. 


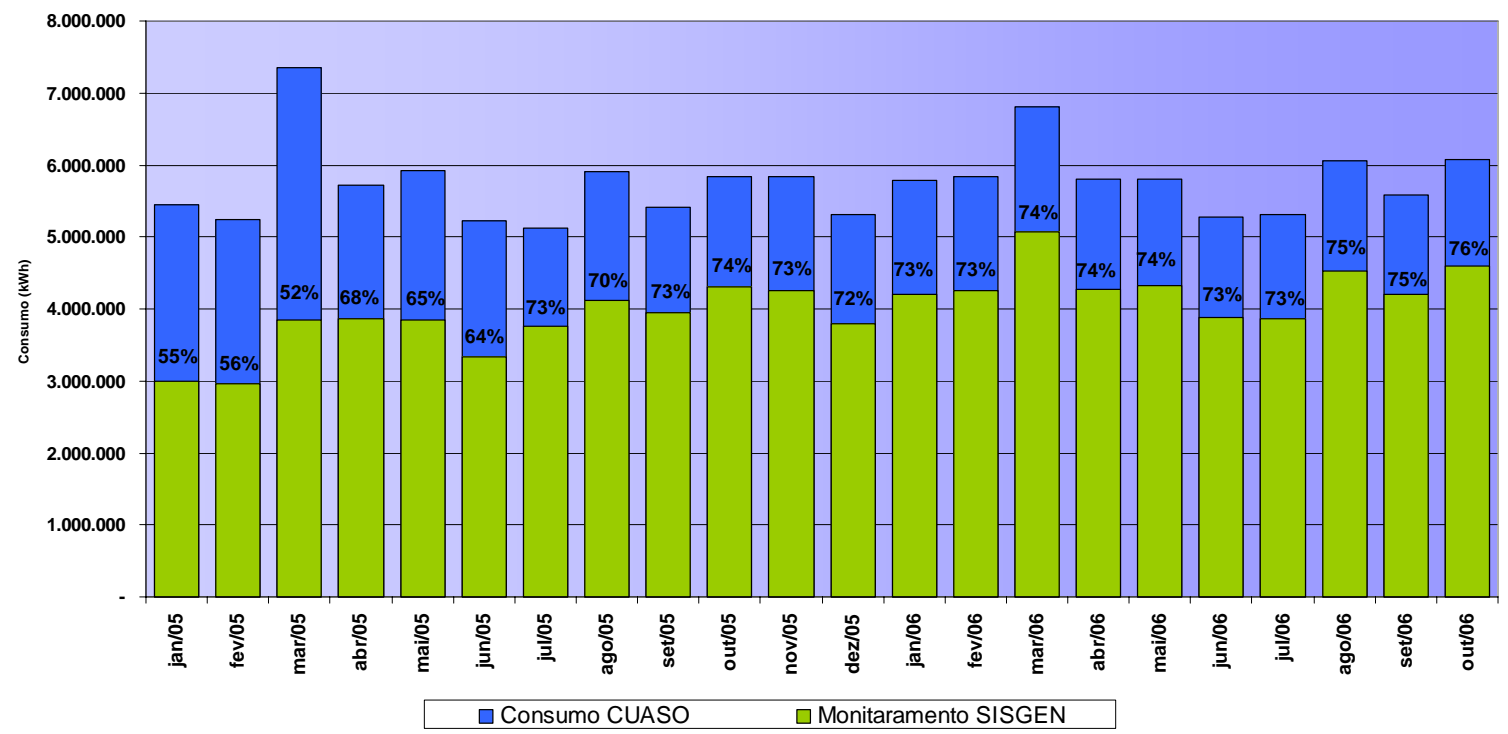

Figura 9: EVOLUÇão DE CONSUMO CUASO - JAN/05 A Nov/06

Com um consumo de aproximadamente 6.000 MWh/mês, a CUASO possui grandes potenciais de economia de recursos com o uso da eletricidade. O monitoramento atual superior a $75 \%$ do total, aliado aos indicadores de energia, pode auxiliar no processo de gestão e economia de recursos disponibilizados para o uso da energia.

Para realizar a classificação por prioridades através dos indicadores de consumo é necessário o levantamento das informações físicas e de ocupação, área de concessão, tipo de atendimento (consumidor cativo ou livre ${ }^{13}$ ), equipamentos utilizados, o perfil de monitoramento e uma classificação prévia por especialidade de ensino ou atividade (tabela 6), que auxilia na identificação de semelhanças de comportamento de consumo em unidades com similaridades de atividades.

\footnotetext{
${ }^{13}$ Consumidor livre: consumidor que pode optar pela compra de energia elétrica junto a qualquer fornecedor, conforme legislação e regulamentos específicos (ANEEL, 2000).
} 
As informações físicas, de ocupação e equipamentos de informática são obtidas através do anuário estatístico da USP (USP, 2005). Informações de outros equipamentos utilizados, como os de iluminação, refrigeração e ar condicionado, exigem um levantamento nas unidades. Sendo assim, para os indicadores por uso dos sistemas de iluminação, serão utilizadas as informações do PUREFA 2006, diagnóstico para substituição de equipamentos de iluminação no Instituto de Psicologia e, para os equipamentos de refrigeração e ar condicionado, serão utilizadas as estimativas com base em SAIDEL et. al. 2006, trabalho desenvolvido na USP que leva em consideração a utilização de informações de temperatura ambiente na previsão de demandas e consumo de energia.

A CUASO está localizada na cidade de São Paulo e, portanto, na área de concessão da AES Eletropaulo, distribuidora de energia que atende a grande São Paulo. Consumidor cativo, a CUASO é submetida a preços de energia e demanda específicos, definidos pelo órgão regulador para a área de concessão da Eletropaulo. Nos indicadores financeiros as informações de gastos com energia serão utilizadas na classificação e para realizar uma comparação com ambiente livre de contratação de energia.

De acordo com a evolução do monitoramento de consumo das unidades na CUASO, em alguns meses e períodos não é possível aplicar os indicadores em todas as unidades ou áreas de especialidade, pois o monitoramento não atinge todas as dependências e unidades. 
TABELA 6: CLASSIFICAÇÃO PRÉVIA POR ESPECIALIDADE DE ENSINO OU ATIVIDADE

\begin{tabular}{|c|c|c|c|c|c|c|c|}
\hline Exatas & Humanas & Biologicas & Saude & Administrativa & Residenciais & Lazer e Cultura & Outras \\
\hline $\begin{array}{c}\text { Escola } \\
\text { Politécnica }\end{array}$ & $\begin{array}{c}\text { Escola de } \\
\text { Comunicação e } \\
\text { Artes }\end{array}$ & $\begin{array}{c}\text { Instituto de } \\
\text { Ciencias } \\
\text { Biologicas }\end{array}$ & $\begin{array}{c}\text { Escola de } \\
\text { Educação Fisica }\end{array}$ & Prefeitura & $\begin{array}{l}\text { CRUSP } \\
\text { (Reitoria) }\end{array}$ & $\begin{array}{c}\text { Centro de } \\
\text { Práticas } \\
\text { Esportivas } \\
\end{array}$ & Terceiros \\
\hline $\begin{array}{c}\text { Faculdade de } \\
\text { Arquitetura e } \\
\text { Urbanismo } \\
\end{array}$ & $\begin{array}{c}\text { Faculdade de } \\
\text { Economia e } \\
\text { Administração } \\
\end{array}$ & $\begin{array}{c}\text { Instituto } \\
\text { Oceanografico }\end{array}$ & $\begin{array}{c}\text { Faculdade de } \\
\text { Ciencias } \\
\text { Farmacêuticas } \\
\end{array}$ & Reitoria & & $\begin{array}{c}\text { Museu de Arte } \\
\text { Contemporânea }\end{array}$ & $\begin{array}{l}\text { Galpões } \\
\text { Provisórios }\end{array}$ \\
\hline $\begin{array}{l}\text { Instituto de } \\
\text { Energia e } \\
\text { Eletrotécnica }\end{array}$ & $\begin{array}{l}\text { Faculdade de } \\
\text { Educação }\end{array}$ & & $\begin{array}{l}\text { Faculdade de } \\
\text { Medicina } \\
\text { Veterinária e } \\
\text { Zootecnia } \\
\end{array}$ & $\begin{array}{l}\text { Centro de } \\
\text { Computação } \\
\text { Eletronica }\end{array}$ & & & \\
\hline $\begin{array}{l}\text { Instituto de } \\
\text { Fisica }\end{array}$ & $\begin{array}{c}\text { Faculdade de } \\
\text { Filosofia, Letras, } \\
\text { Ciências Sociais } \\
\text { e História }\end{array}$ & & $\begin{array}{l}\text { Faculdade de } \\
\text { Odontologia }\end{array}$ & & & & \\
\hline $\begin{array}{c}\text { Instituto de } \\
\text { Matemática e } \\
\text { Estatística }\end{array}$ & $\begin{array}{l}\text { Instituto de } \\
\text { Psicologia }\end{array}$ & & $\begin{array}{c}\text { Hospital } \\
\text { Universitario }\end{array}$ & & & & \\
\hline $\begin{array}{c}\text { Instituto de } \\
\text { Química } \\
\end{array}$ & Creche Central & & & & & & \\
\hline \multicolumn{8}{|l|}{$\begin{array}{l}\text { Instituto de } \\
\text { Geociência }\end{array}$} \\
\hline $\begin{array}{c}\text { Instituto de } \\
\text { Astronomia e } \\
\text { Geociência }\end{array}$ & & & & & & & \\
\hline
\end{tabular}

\subsection{Perfil de Monitoramento - CUASO.}

Para identificar o perfil de monitoramento da CUASO, utilizou-se da curva de carga média do mês de Outubro de 2006, em que, mostra que a maior parte do consumo monitorado está entre 08:00 e 21:00 h. Áreas externas às unidades, como vias públicas, não possuíam monitoramento até aquele mês, por isso, o percentual menor nos horários das 22:00 as 07:00 h. 


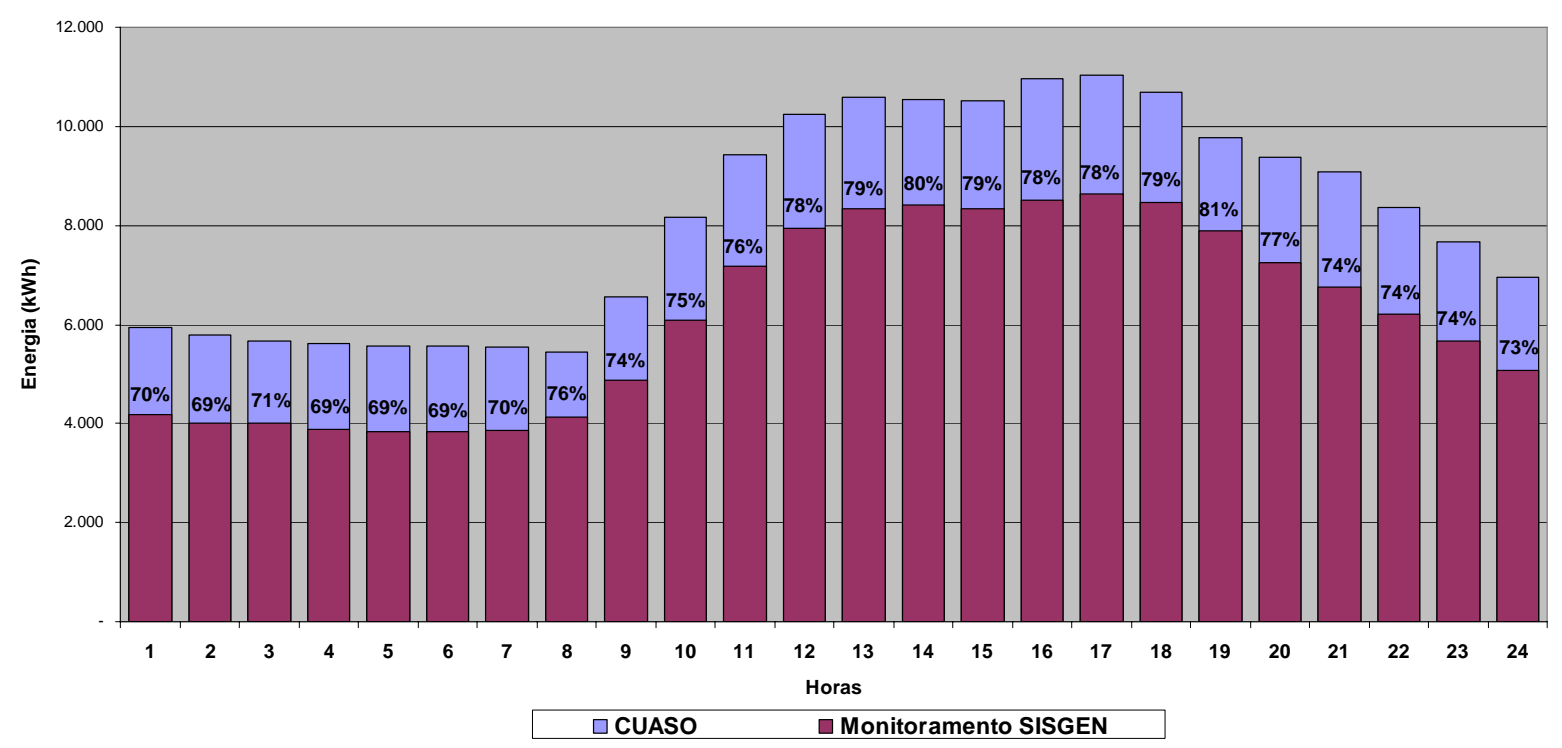

Figura 10: Curva de Carga MÉdia Mensal - Outubro 2006

O gráfico de consumo diário aponta que o percentual de monitoramento aumenta consideravelmente nos dias não úteis.

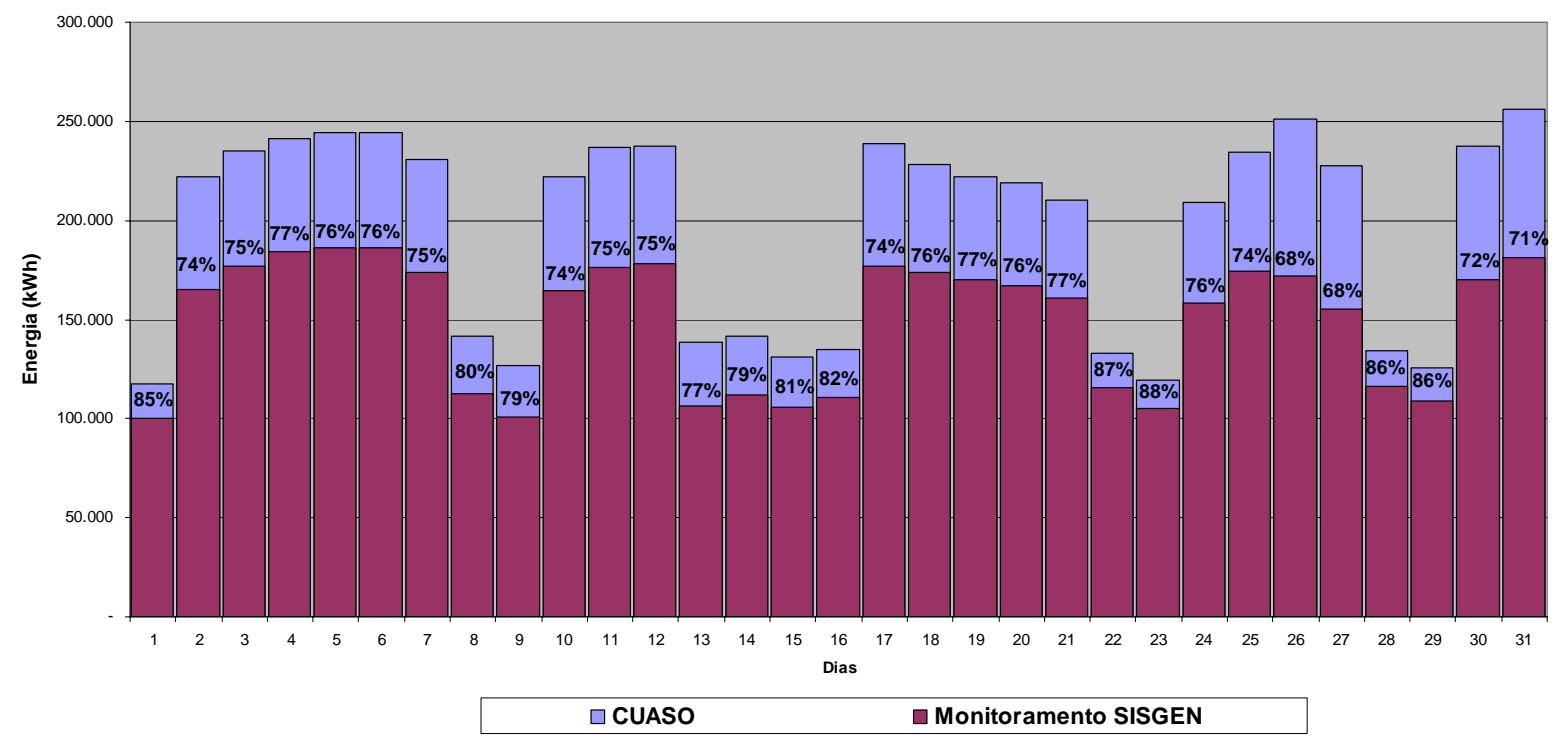

FIgURA 11: CONSUMO TOTAL X MONITORAMENTO SISGEN - OUTUBRO 2006

Para analisar melhor o perfil de consumo utilizaram-se comparações com as médias de dias úteis e não úteis. O monitoramento nos horários noturnos não sofre 
alterações consideráveis, no entanto, entre 08:00 e 21:00 h, os dias úteis possuem percentuais bem abaixo dos dias não úteis.

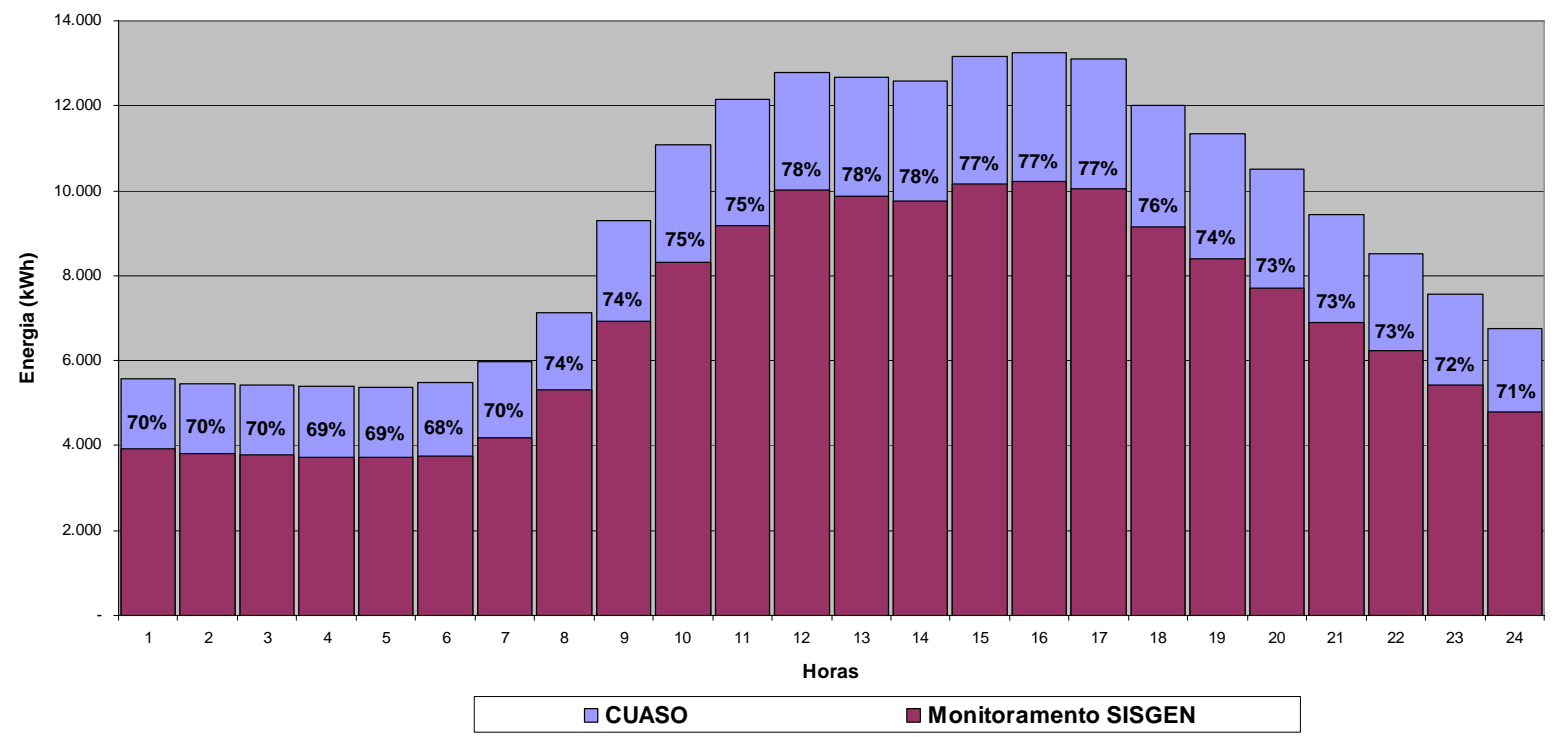

Figura 12: CuRva De CARGa MÉdia - Dias Úteis - Outubro 2006

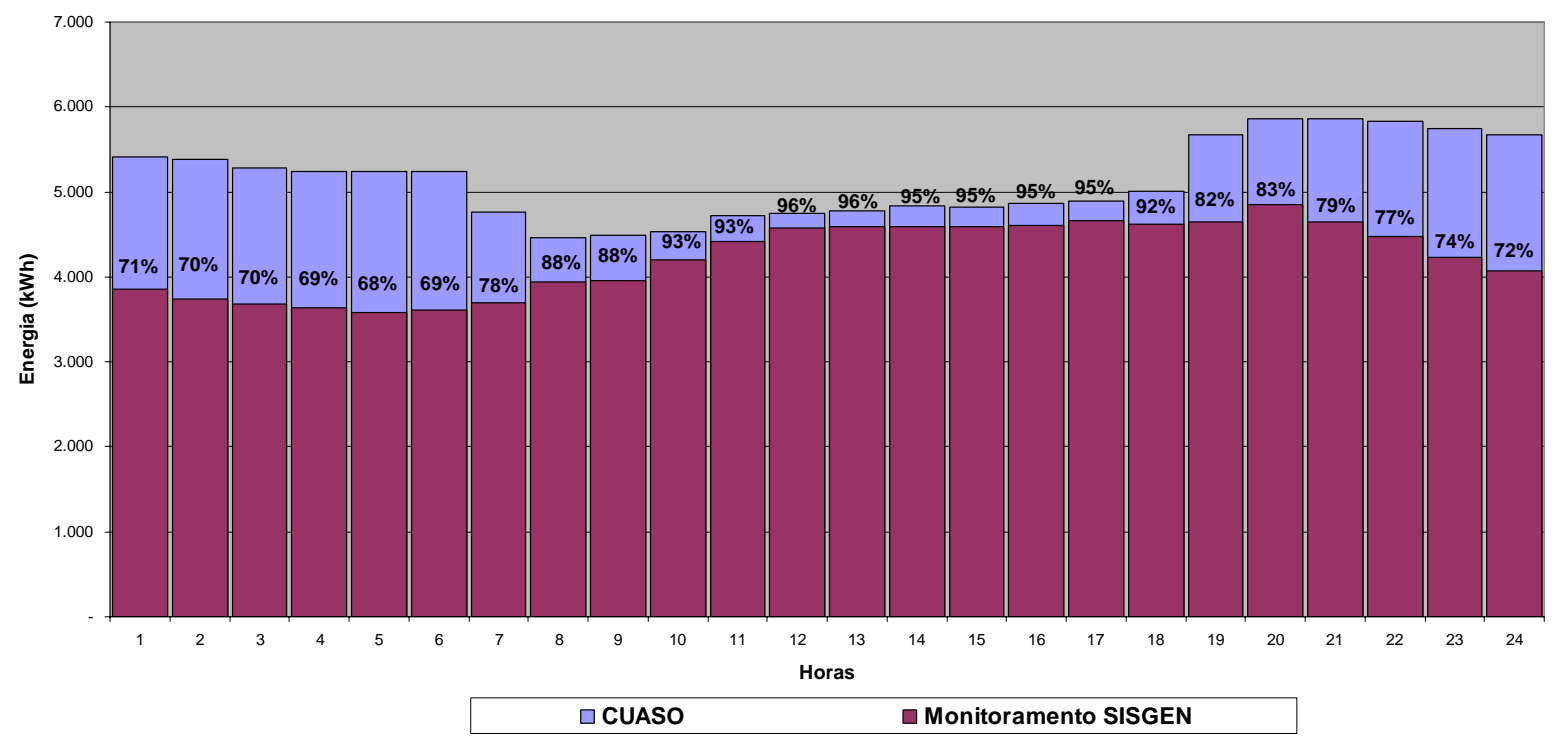

Figura 13: CURVA DE CARGa MÉdia - Dias NÃo ÚteIS - OUtUBro 2006

Observa-se que o monitoramento da CUASO prioriza as unidades com maior movimentação nos dias úteis, ou seja, leva em consideração a ocupação das unidades. Pode-se citar que, embora o monitoramento seja maior, o consumo é 
significativamente alto nos dias não úteis, considerando-se o perfil de atividades desenvolvidas na maioria das unidades, ou seja, atividades de ensino e educação.

\subsection{Classificação por Fator de Potência}

Para realizar a classificação por fator de potência foram consideradas as informações do mês de outubro de 2006, pois para efeitos de correções devem-se considerar as condições mais atuais das instalações.

Embora o consumo total da CUASO seja composto por várias unidades consumidoras, somente a medição no ponto de entrega da concessionária é utilizada para faturamento e, sendo assim, a única que está sujeita a penalidades por ultrapassagem dos valores mínimos de Fator de Potência. No mês de outubro de 2006 o fator de potência mínimo da CUASO foi de 0,90, ou seja, abaixo do mínimo exigido pelo órgão regulador e, portanto, houve o pagamento de penalidades no faturamento desse mês.

Os valores que compõem o cálculo do fator de potência da CUASO são as somatórias das energias ativa e reativa do campus, ou seja, todas as unidades e instalações internas têm participação direta e, sendo assim, é necessário que estejam adequadas, evitando assim penalidades e sobrecarga dos alimentadores.

As unidades foram classificadas por ordem decrescente consumo de energia reativa e crescente por fator de potência mínimo, priorizando assim as unidades de maior consumo, que contribuem em maiores proporções na composição do cálculo. As 
unidades que possuíam valores adequados tornaram-se as ultimas na lista de prioridades.

TABELA 7: ClasSIFICAÇÃO POR FATOR DE POTÊNCIA

\begin{tabular}{|c|c|c|c|}
\hline UNIDADES & $\begin{array}{c}\text { Energia Reativa } \\
\text { (kVAr) }\end{array}$ & $\begin{array}{l}\text { Fator de } \\
\text { Potência }\end{array}$ & Prioridade \\
\hline HU & $229.381,16$ & 0,86 & $1^{\circ}$ \\
\hline ICB 2 & $148.133,24$ & 0,79 & $2^{0}$ \\
\hline IF restaurante & $137.022,04$ & 0,80 & $3^{\circ}$ \\
\hline ICB 1 & $126.333,07$ & 0,77 & $4^{\circ}$ \\
\hline Veterinaria & $114.626,31$ & 0,70 & $5^{\circ}$ \\
\hline Quimica Bioterio & $112.249,32$ & 0,71 & $6^{\circ}$ \\
\hline FEA & $108.591,71$ & 0,60 & $7^{\circ}$ \\
\hline Poli Eletrica & $90.415,38$ & 0,84 & $8^{\circ}$ \\
\hline ICB 4 & $87.242,86$ & 0,63 & $9^{\circ}$ \\
\hline Inst Geociencias & $76.739,64$ & 0,71 & $10^{\circ}$ \\
\hline CCE & $70.996,59$ & 0,87 & $11^{\circ}$ \\
\hline Odonto & $66.773,58$ & 0,74 & $12^{\circ}$ \\
\hline EP Hidraulica Lab & $65.511,03$ & 0,58 & $13^{\circ}$ \\
\hline Farmacia 1317 & $64.933,64$ & 0,71 & $14^{\circ}$ \\
\hline Matematica & $55.604,48$ & 0,79 & $15^{\circ}$ \\
\hline CRUSP G & $52.214,52$ & 0,79 & $16^{\circ}$ \\
\hline Ciencias Sociais Letras & $44.117,28$ & 0,70 & $17^{\circ}$ \\
\hline Quimica semi industrial & $43.116,54$ & 0,58 & $18^{\circ}$ \\
\hline Poli Naval & $40.539,01$ & 0,93 & $19^{\circ}$ \\
\hline Metalurgia & $38.033,11$ & 0,72 & $20^{\circ}$ \\
\hline Inst Oceanografico & $37.024,51$ & 0,78 & $21^{\circ}$ \\
\hline MAC & $35.721,21$ & 0,92 & $22^{\circ}$ \\
\hline Poli Civil & $35.405,65$ & 0,85 & $23^{\circ}$ \\
\hline Galpoes Provisorios & $31.644,14$ & 0,80 & $24^{\circ}$ \\
\hline CRUSP B & $29.945,27$ & 0,90 & $25^{\circ}$ \\
\hline Faculdade Educaçao & $24.098,98$ & 0,72 & $26^{\circ}$ \\
\hline Educaçao Fisica & $23.060,13$ & 0,80 & $27^{\circ}$ \\
\hline Farmacia 13a 13b & $19.681,57$ & 0,76 & $28^{\circ}$ \\
\hline Historia Geografia & $18.998,20$ & 0,60 & $29^{\circ}$ \\
\hline IAG & $18.353,23$ & 0,97 & $30^{\circ}$ \\
\hline CEPE Quadras & $17.035,41$ & 0,64 & $31^{\circ}$ \\
\hline Banco Real & $16.423,48$ & 0,80 & $32^{\circ}$ \\
\hline ECA Predios & $15.643,93$ & 0,39 & $33^{\circ}$ \\
\hline ECA Sintusp & $15.578,64$ & 0,78 & $34^{\circ}$ \\
\hline Psicologia & $15.427,80$ & 0,75 & $35^{\circ}$ \\
\hline IF Tokamac adm & $15.144,54$ & 0,39 & $36^{\circ}$ \\
\hline IEE clube funcionarios & $14.044,52$ & 0,68 & $37^{\circ}$ \\
\hline Fazendaria & $13.355,51$ & 0,47 & $38^{\circ}$ \\
\hline PCO & $13.106,17$ & 0,83 & $39^{\circ}$ \\
\hline Reitoria & $12.800,64$ & 0,97 & $40^{\circ}$ \\
\hline IEE ener solar & $12.450,17$ & 0,49 & $41^{\circ}$ \\
\hline Bienio & $11.482,13$ & 0,81 & $42^{\circ}$ \\
\hline Poli Quimica & $9.777,64$ & 0,78 & $43^{\circ}$ \\
\hline FAU & $9.258,90$ & 0,72 & $44^{\circ}$ \\
\hline EP Hidraulica & $4.198,87$ & 0,36 & $45^{\circ}$ \\
\hline FFLCH adm & $3.743,91$ & 0,71 & $46^{\circ}$ \\
\hline Creche Central & $2.939,17$ & 0,42 & $47^{\circ}$ \\
\hline Biblioteca das Quimicas & $2.007,90$ & 0,49 & $48^{\circ}$ \\
\hline
\end{tabular}




\subsection{Classificação por Fator de Carga}

Para classificar as instalações pelo fator de carga foram considerados dois períodos distintos, período letivo e férias escolares, em que, há uma grande mudança na utilização das instalações da universidade, sobretudo, no uso da energia elétrica. Durante o período letivo, em que, a maioria dos usuários utiliza as instalações diariamente, a influência da utilização das instalações contribui de maneira mais acentuada no comportamento da demanda e consumo da energia elétrica e, no período de férias e recesso escolar, esta influência tende a diminuir.

Consideraram-se para a classificação o fator de carga médio e desvio-padrão dos períodos, ordenados por ordem decrescente pela diferença entre os períodos e por ordem crescente por fator de carga. Esta classificação visa auxiliar a avaliação das unidades com o objetivo de melhorar o fator de carga global, a CUASO. O fator de carga da CUASO é referência para a celebração de contratos de uso dos sistemas de transmissão e distribuição e influenciam diretamente no faturamento pelo uso da eletricidade.

A comparação por fator de carga dentro das especialidades de ensino/atividades desenvolvidas visa auxiliar a avaliação levando-se em consideração a similaridade no comportamento da demanda e consumo da energia elétrica. 
TABELA 8: ClassificAÇÃO POR FATOR DE CARGA

\begin{tabular}{|c|c|c|c|c|c|}
\hline UNIDADES & Periodo Férias & Desvio Padrão & Periodo Letivo & Desvio Padrão & Prioridade \\
\hline Quimica Bioterio & 0,63 & $8 \%$ & 0,47 & $21 \%$ & $1^{0}$ \\
\hline IEE ener solar & 0,27 & $13 \%$ & 0,34 & $13 \%$ & $2^{\circ}$ \\
\hline Biblioteca das Quimicas & 0,36 & $4 \%$ & 0,43 & $4 \%$ & $3^{\circ}$ \\
\hline ECA Predios & 0,42 & $8 \%$ & 0,35 & $8 \%$ & $4^{0}$ \\
\hline Creche Central & 0,24 & $4 \%$ & 0,30 & $6 \%$ & $5^{\circ}$ \\
\hline Faculdade Educaçao & 0,34 & $3 \%$ & 0,40 & $3 \%$ & $6^{\circ}$ \\
\hline PCO & 0,47 & $3 \%$ & 0,41 & $4 \%$ & $7^{0}$ \\
\hline ECA Sintusp & 0,36 & $5 \%$ & 0,41 & $6 \%$ & $8^{\circ}$ \\
\hline Galpoes Provisorios & 0,40 & $8 \%$ & 0,45 & $3 \%$ & $9^{\circ}$ \\
\hline IEE clube funcionarios & 0,50 & $21 \%$ & 0,45 & $22 \%$ & $10^{\circ}$ \\
\hline Ciencias Sociais Letras & 0,40 & $3 \%$ & 0,44 & $4 \%$ & $11^{\circ}$ \\
\hline Educaçao Fisica & 0,36 & $4 \%$ & 0,40 & $4 \%$ & $12^{\circ}$ \\
\hline Psicologia & 0,42 & $4 \%$ & 0,46 & $4 \%$ & $13^{\circ}$ \\
\hline Odonto & 0,36 & $3 \%$ & 0,40 & $4 \%$ & $14^{\circ}$ \\
\hline IF restaurante & 0,53 & $5 \%$ & 0,49 & $11 \%$ & $15^{\circ}$ \\
\hline FEA & 0,34 & $3 \%$ & 0,36 & $5 \%$ & $16^{\circ}$ \\
\hline FAU & 0,35 & $4 \%$ & 0,38 & $5 \%$ & $17^{\circ}$ \\
\hline EP Hidraulica & 0,23 & $14 \%$ & 0,20 & $11 \%$ & $18^{\circ}$ \\
\hline CRUSP G & 0,45 & $10 \%$ & 0,43 & $4 \%$ & $19^{\circ}$ \\
\hline Fazendaria & 0,27 & $8 \%$ & 0,29 & $5 \%$ & $20^{\circ}$ \\
\hline Historia Geografia & 0,39 & $3 \%$ & 0,40 & $4 \%$ & $21^{\circ}$ \\
\hline EP Hidraulica Lab & 0,24 & $5 \%$ & 0,25 & $4 \%$ & $22^{\circ}$ \\
\hline Matematica & 0,51 & $4 \%$ & 0,52 & $4 \%$ & $23^{\circ}$ \\
\hline IF Tokamac adm & 0,30 & $4 \%$ & 0,28 & $4 \%$ & $24^{\circ}$ \\
\hline Veterinaria & 0,45 & $3 \%$ & 0,44 & $3 \%$ & $25^{\circ}$ \\
\hline Inst Oceanografico & 0,42 & $5 \%$ & 0,41 & $4 \%$ & $26^{\circ}$ \\
\hline ICB 4 & 0,50 & $5 \%$ & 0,49 & $3 \%$ & $27^{\circ}$ \\
\hline Bienio & 0,20 & $20 \%$ & 0,31 & $13 \%$ & $28^{\circ}$ \\
\hline CCE & 0,62 & $5 \%$ & 0,62 & $5 \%$ & $29^{\circ}$ \\
\hline Poli Naval & 0,41 & $6 \%$ & 0,41 & $5 \%$ & $30^{\circ}$ \\
\hline CEPE Quadras & 0,24 & $5 \%$ & 0,25 & $4 \%$ & $31^{\circ}$ \\
\hline CRUSP B & 0,61 & $3 \%$ & 0,62 & $4 \%$ & $32^{\circ}$ \\
\hline Reitoria & 0,33 & $5 \%$ & 0,35 & $4 \%$ & $33^{\circ}$ \\
\hline Poli Eletrica & 0,42 & $4 \%$ & 0,43 & $4 \%$ & $34^{\circ}$ \\
\hline Poli Quimica & 0,38 & $6 \%$ & 0,39 & $3 \%$ & $35^{\circ}$ \\
\hline Banco Real & 0,31 & $2 \%$ & 0,30 & $2 \%$ & $36^{\circ}$ \\
\hline Inst Geociencias & 0,49 & $5 \%$ & 0,48 & $5 \%$ & $37^{\circ}$ \\
\hline IAG & 0,45 & $18 \%$ & 0,44 & $14 \%$ & $38^{\circ}$ \\
\hline ICB 2 & 0,51 & $4 \%$ & 0,51 & $4 \%$ & $39^{\circ}$ \\
\hline MAC & 0,64 & $8 \%$ & 0,64 & $7 \%$ & $40^{\circ}$ \\
\hline Farmacia 13a 13b & 0,39 & $5 \%$ & 0,39 & $4 \%$ & $41^{\circ}$ \\
\hline Quimica semi industrial & 0,49 & $3 \%$ & 0,49 & $2 \%$ & $42^{\circ}$ \\
\hline ICB 1 & 0,47 & $2 \%$ & 0,48 & $4 \%$ & $43^{\circ}$ \\
\hline Metalurgia & 0,39 & $5 \%$ & 0,39 & $3 \%$ & $44^{\circ}$ \\
\hline Farmacia 1317 & 0,39 & $4 \%$ & 0,40 & $2 \%$ & $45^{\circ}$ \\
\hline $\mathrm{HU}$ & 0,64 & $3 \%$ & 0,64 & $2 \%$ & $46^{\circ}$ \\
\hline FFLCH adm & - & - & 0,18 & $8 \%$ & $47^{\circ}$ \\
\hline Poli Civil & - & - & 0,42 & $1 \%$ & $48^{\circ}$ \\
\hline CUASO & 0,51 & $3 \%$ & 0,52 & $5 \%$ & \\
\hline
\end{tabular}


TABELA 9: FATOR DE CARGA POR ESPECIALIDADE/ATIVIDADE

\begin{tabular}{|c|c|c|c|c|c|c|}
\hline & UNIDADES & Periodo Férias & Desvio Padrão & Periodo Letivo & Desvio Padrão & Prioridade \\
\hline \multirow{19}{*}{ Exatas } & Quimica Bioterio & 0,63 & $8 \%$ & 0,47 & $21 \%$ & 1 \\
\hline & IEE ener solar & 0,27 & $13 \%$ & 0,34 & $13 \%$ & 2 \\
\hline & Biblioteca das Quimicas & 0,36 & $4 \%$ & 0,43 & $4 \%$ & 3 \\
\hline & IEE clube funcionarios & 0,50 & $21 \%$ & 0,45 & $22 \%$ & 10 \\
\hline & IF restaurante & 0,53 & $5 \%$ & 0,49 & $11 \%$ & 15 \\
\hline & FAU & 0,35 & $4 \%$ & 0,38 & $5 \%$ & 17 \\
\hline & EP Hidraulica & 0,23 & $14 \%$ & 0,20 & $11 \%$ & 18 \\
\hline & EP Hidraulica Lab & 0,24 & $5 \%$ & 0,25 & $4 \%$ & 22 \\
\hline & \begin{tabular}{|l|} 
Matematica \\
\end{tabular} & 0,51 & $4 \%$ & 0,52 & $4 \%$ & 23 \\
\hline & IF Tokamac adm & 0,30 & $4 \%$ & 0,28 & $4 \%$ & 24 \\
\hline & Bienio & 0,20 & $20 \%$ & 0,31 & $13 \%$ & 28 \\
\hline & \begin{tabular}{|l} 
Poli Naval \\
\end{tabular} & 0,41 & $6 \%$ & 0,41 & $5 \%$ & 30 \\
\hline & Poli Eletrica & 0,42 & $4 \%$ & 0,43 & $4 \%$ & 34 \\
\hline & Poli Quimica & 0,38 & $6 \%$ & 0,39 & $3 \%$ & 35 \\
\hline & \begin{tabular}{|l|} 
Inst Geociencias \\
\end{tabular} & 0,49 & $5 \%$ & 0,48 & $5 \%$ & 37 \\
\hline & IAG & 0,45 & $18 \%$ & 0,44 & $14 \%$ & 38 \\
\hline & Quimica semi industrial & 0,49 & $3 \%$ & 0,49 & $2 \%$ & 42 \\
\hline & Metalurgia & 0,39 & $5 \%$ & 0,39 & $3 \%$ & 44 \\
\hline & Poli Civil & - & - & 0,42 & $1 \%$ & 48 \\
\hline \multirow{11}{*}{ Humanas } & ECA Predios & 0,42 & $8 \%$ & 0,35 & $8 \%$ & 4 \\
\hline & Creche Central & 0,24 & $4 \%$ & 0,30 & $6 \%$ & 5 \\
\hline & Faculdade Educaçao & 0,34 & $3 \%$ & 0,40 & $3 \%$ & 6 \\
\hline & ECA Sintusp & 0,36 & $5 \%$ & 0,41 & $6 \%$ & 8 \\
\hline & Ciencias Sociais Letras & 0,40 & $3 \%$ & 0,44 & $4 \%$ & 11 \\
\hline & Educaçao Fisica & 0,36 & $4 \%$ & 0,40 & $4 \%$ & 12 \\
\hline & Psicologia & 0,42 & $4 \%$ & 0,46 & $4 \%$ & 13 \\
\hline & FEA & 0,34 & $3 \%$ & 0,36 & $5 \%$ & 16 \\
\hline & Fazendaria & 0,27 & $8 \%$ & 0,29 & $5 \%$ & 20 \\
\hline & Historia Geografia & 0,39 & $3 \%$ & 0,40 & $4 \%$ & 21 \\
\hline & FFLCH adm & - & - & 0,18 & $8 \%$ & 47 \\
\hline \multirow{5}{*}{ Saude } & Odonto & 0,36 & $3 \%$ & 0,40 & $4 \%$ & 14 \\
\hline & Veterinaria & 0,45 & $3 \%$ & 0,44 & $3 \%$ & 25 \\
\hline & Farmacia 13a 13b & 0,39 & $5 \%$ & 0,39 & $4 \%$ & 41 \\
\hline & \begin{tabular}{|l|} 
Farmacia 1317 \\
\end{tabular} & 0,39 & $4 \%$ & 0,40 & $2 \%$ & 45 \\
\hline & $\mathrm{HU}$ & 0,64 & $3 \%$ & 0,64 & $2 \%$ & 46 \\
\hline \multirow{4}{*}{ Biologicas } & Inst Oceanografico & 0,42 & $5 \%$ & 0,41 & $4 \%$ & 26 \\
\hline & ICB 4 & 0,50 & $5 \%$ & 0,49 & $3 \%$ & 27 \\
\hline & \begin{tabular}{|l|} 
ICB 2 \\
\end{tabular} & 0,51 & $4 \%$ & 0,51 & $4 \%$ & 39 \\
\hline & ICB 1 & 0,47 & $2 \%$ & 0,48 & $4 \%$ & 43 \\
\hline \multirow{3}{*}{ Administrativa } & PCO & 0,47 & $3 \%$ & 0,41 & $4 \%$ & 7 \\
\hline & CCE & 0,62 & $5 \%$ & 0,62 & $5 \%$ & 29 \\
\hline & Reitoria & 0,33 & $5 \%$ & 0,35 & $4 \%$ & 33 \\
\hline \multirow{2}{*}{ Residenciais } & CRUSP G & 0,45 & $10 \%$ & 0,43 & $4 \%$ & 19 \\
\hline & CRUSP B & 0,61 & $3 \%$ & 0,62 & $4 \%$ & 32 \\
\hline \multirow{2}{*}{ Lazer e Cultura } & CEPE Quadras & 0,24 & $5 \%$ & 0,25 & $4 \%$ & 31 \\
\hline & MAC & 0,64 & $8 \%$ & 0,64 & $7 \%$ & 40 \\
\hline \multirow{2}{*}{ Outras } & Galpoes Provisorios & 0,40 & $8 \%$ & 0,45 & $3 \%$ & 9 \\
\hline & Banco Real & 0,31 & $2 \%$ & 0,30 & $2 \%$ & 36 \\
\hline
\end{tabular}




\subsection{Classificação por Horários de Utilização}

Para classificar as unidades em horários específicos de consumo de energia elétrica utilizou-se o indicador PCR em dois intervalos, sendo o consumo entre as 20:00 e 06:00 h e das 0:00 as 06:00 h, com base nas médias mensais totais e dos intervalos considerados, no período de janeiro de 2005 a outubro de 2006.

O indicador PCR é utilizado no intuito de identificar consumos de energia desnecessários, em horários com baixa atividade humana nas unidades. Tem o intuito de apontar os potenciais de redução de consumo de energia elétrica, com ações simples de conscientização e mudança de hábitos.

As prioridades foram ordenadas de maneira decrescente, de acordo com o resultado obtido nos horários verificados. A separação em dois períodos visa auxiliar na avaliação das unidades, considerando o consumo nos horários noturnos e, a separação pela classificação prévia auxilia na identificação das similaridades entre as unidades verificadas. 
TABELA 10: ClAsSIFICAÇÃO POR HORÁRIOS DE UTILIZAÇÃO

\begin{tabular}{|c|c|c|c|c|c|c|}
\hline UNIDADES & $\begin{array}{c}\text { Consumo Total } \\
\text { (kWh) }\end{array}$ & $\begin{array}{c}\text { Consumo } 0 \text { as } 6 \\
(\mathrm{kWh})\end{array}$ & $\begin{array}{c}\text { Consumo } 20 \text { as } 6 \\
(\mathrm{kWh})\end{array}$ & PCR 0 as 6 & PCR 20 as 6 & Prioridade \\
\hline IEE clube funcionarios & $15.086,38$ & $3.378,62$ & $5.535,17$ & 0,22 & 0,37 & $1^{\circ}$ \\
\hline Quimica Bioterio & $100.724,26$ & $22.457,47$ & $37.086,75$ & 0,22 & 0,37 & $2^{\circ}$ \\
\hline CCE & $159.471,06$ & $34.414,29$ & $52.474,42$ & 0,22 & 0,33 & $3^{\circ}$ \\
\hline MAC & $108.915,49$ & $22.798,24$ & $39.286,38$ & 0,21 & 0,36 & $4^{\circ}$ \\
\hline PCO & $37.854,15$ & $7.448,29$ & $12.573,97$ & 0,20 & 0,33 & $5^{\circ}$ \\
\hline ICB 4 & $78.695,02$ & $15.030,17$ & $25.401,87$ & 0,19 & 0,32 & $6^{\circ}$ \\
\hline $\mathrm{HU}$ & $512.271,31$ & $95.776,92$ & $151.474,65$ & 0,19 & 0,30 & $7^{\circ}$ \\
\hline CRUSP B & $87.488,32$ & $16.201,54$ & $28.879,00$ & 0,19 & 0,33 & $8^{\circ}$ \\
\hline IAG & $74.877,91$ & $13.777,45$ & $21.723,46$ & 0,18 & 0,29 & $9^{\circ}$ \\
\hline Quimica semi industrial & $45.880,51$ & $8.412,10$ & $12.901,46$ & 0,18 & 0,28 & $10^{\circ}$ \\
\hline ICB 2 & $209.156,92$ & $37.504,36$ & $58.267,44$ & 0,18 & 0,28 & $11^{\circ}$ \\
\hline IF restaurante & $183.418,38$ & $32.562,14$ & $52.870,82$ & 0,18 & 0,29 & $12^{\circ}$ \\
\hline IEE ener solar & $8.889,21$ & $1.535,51$ & $2.313,08$ & 0,17 & 0,26 & $13^{\circ}$ \\
\hline ICB 1 & $227.390,29$ & $38.750,82$ & $60.151,94$ & 0,17 & 0,26 & $14^{\circ}$ \\
\hline Inst Geociencias & $120.962,74$ & $20.559,24$ & $32.351,83$ & 0,17 & 0,27 & $15^{\circ}$ \\
\hline Veterinaria & $199.664,45$ & $33.434,50$ & $51.463,15$ & 0,17 & 0,26 & $16^{\circ}$ \\
\hline EP Hidraulica & $6.193,42$ & $1.021,72$ & $1.628,52$ & 0,16 & 0,26 & $17^{\circ}$ \\
\hline Matematica & $120.008,15$ & $19.661,64$ & $32.392,05$ & 0,16 & 0,27 & $18^{\circ}$ \\
\hline Poli Eletrica & $187.470,52$ & $29.981,29$ & $46.908,19$ & 0,16 & 0,25 & $19^{\circ}$ \\
\hline Psicologia & $38.011,64$ & $5.949,52$ & $9.451,69$ & 0,16 & 0,25 & $20^{\circ}$ \\
\hline CRUSP G & $74.496,08$ & $11.436,05$ & $20.268,69$ & 0,15 & 0,27 & $21^{\circ}$ \\
\hline Creche Central & $9.120,83$ & $1.388,64$ & $2.156,13$ & 0,15 & 0,24 & $22^{\circ}$ \\
\hline Poli Naval & $122.154,70$ & $18.181,42$ & $29.391,09$ & 0,15 & 0,24 & $23^{\circ}$ \\
\hline Farmacia 13a 13b & $42.528,51$ & $6.213,03$ & $9.706,21$ & 0,15 & 0,23 & $24^{\circ}$ \\
\hline Inst Oceanografico & $76.344,76$ & $10.942,85$ & $17.056,71$ & 0,14 & 0,22 & $25^{\circ}$ \\
\hline Poli Quimica & $24.268,01$ & $3.315,41$ & $5.292,36$ & 0,14 & 0,22 & $26^{\circ}$ \\
\hline EP Hidraulica Lab & $97.632,55$ & $13.316,45$ & $20.950,84$ & 0,14 & 0,21 & $27^{\circ}$ \\
\hline Galpoes Provisorios & $84.745,23$ & $11.520,36$ & $18.656,55$ & 0,14 & 0,22 & $28^{\circ}$ \\
\hline Farmacia 1317 & $106.204,18$ & $14.437,04$ & $23.024,60$ & 0,14 & 0,22 & $29^{\circ}$ \\
\hline IF Tokamac adm & $8.682,05$ & $1.160,91$ & $1.789,47$ & 0,13 & 0,21 & $30^{\circ}$ \\
\hline FFLCH adm & $1.753,72$ & 229,15 & 344,43 & 0,13 & 0,20 & $31^{\circ}$ \\
\hline Poli Civil & $13.056,70$ & $1.675,61$ & $2.782,15$ & 0,13 & 0,21 & $32^{\circ}$ \\
\hline Educaçao Fisica & $43.385,19$ & $5.468,66$ & $8.976,46$ & 0,13 & 0,21 & $33^{\circ}$ \\
\hline Metalurgia & $35.614,84$ & $4.329,96$ & $7.446,75$ & 0,12 & 0,21 & $34^{\circ}$ \\
\hline FEA & $153.062,48$ & $18.570,68$ & $34.808,43$ & 0,12 & 0,23 & $35^{\circ}$ \\
\hline Odonto & $121.042,85$ & $14.406,17$ & $25.181,90$ & 0,12 & 0,21 & $36^{\circ}$ \\
\hline CEPE Quadras & $26.900,91$ & $3.109,30$ & $6.800,61$ & 0,12 & 0,25 & $37^{\circ}$ \\
\hline ECA Sintusp & $26.885,95$ & $3.028,41$ & $5.668,69$ & 0,11 & 0,21 & $38^{\circ}$ \\
\hline Historia Geografia & $39.932,25$ & $4.380,94$ & $8.298,38$ & 0,11 & 0,21 & $39^{\circ}$ \\
\hline Banco Real & $27.631,31$ & $2.904,38$ & $4.906,41$ & 0,11 & 0,18 & $40^{\circ}$ \\
\hline Bienio & $18.571,75$ & $1.934,55$ & $3.609,66$ & 0,10 & 0,19 & $41^{\circ}$ \\
\hline Ciencias Sociais Letras & $89.476,59$ & $9.282,47$ & $17.905,26$ & 0,10 & 0,20 & $42^{\circ}$ \\
\hline Reitoria & $81.753,90$ & $8.354,37$ & $13.193,14$ & 0,10 & 0,16 & $43^{\circ}$ \\
\hline FAU & $52.253,40$ & $5.184,13$ & $9.050,89$ & 0,10 & 0,17 & $44^{\circ}$ \\
\hline Fazendaria & $17.862,77$ & $1.763,56$ & $3.620,32$ & 0,10 & 0,20 & $45^{\circ}$ \\
\hline ECA Predios & $13.867,82$ & $1.359,79$ & $3.332,85$ & 0,10 & 0,24 & $46^{\circ}$ \\
\hline Faculdade Educaçao & $58.335,38$ & $5.397,96$ & $9.931,87$ & 0,09 & 0,17 & $47^{\circ}$ \\
\hline Biblioteca das Quimicas & $10.896,38$ & 961,69 & $1.765,19$ & 0,09 & 0,16 & $48^{\circ}$ \\
\hline CUASO & $5.757 .818,41$ & $1.015 .660,74$ & $1.611 .250,75$ & 0,18 & 0,28 & \\
\hline
\end{tabular}


TABELA 11: HORÁRIOS DE UTILIZAÇÃO POR ESPECIALIDADE/ATIVIDADE

\begin{tabular}{|c|c|c|c|c|}
\hline & UNIDADES & PCR 0 as 6 & PCR 20 as 6 & Prioridade \\
\hline \multirow{19}{*}{ Exatas } & Quimica Bioterio & 0,22 & 0,37 & $2^{0}$ \\
\hline & IEE clube funcionarios & 0,22 & 0,37 & $1^{0}$ \\
\hline & IAG & 0,18 & 0,29 & $9^{\circ}$ \\
\hline & IF restaurante & 0,18 & 0,29 & $12^{\circ}$ \\
\hline & Quimica semi industrial & 0,18 & 0,28 & $10^{\circ}$ \\
\hline & Matematica & 0,16 & 0,27 & $18^{\circ}$ \\
\hline & Inst Geociencias & 0,17 & 0,27 & $15^{\circ}$ \\
\hline & EP Hidraulica & 0,16 & 0,26 & $17^{\circ}$ \\
\hline & IEE ener solar & 0,17 & 0,26 & $13^{0}$ \\
\hline & Poli Eletrica & 0,16 & 0,25 & $19^{\circ}$ \\
\hline & Poli Naval & 0,15 & 0,24 & $23^{\circ}$ \\
\hline & Poli Quimica & 0,14 & 0,22 & $26^{\circ}$ \\
\hline & EP Hidraulica Lab & 0,14 & 0,21 & $27^{\circ}$ \\
\hline & Poli Civil & 0,13 & 0,21 & $32^{\circ}$ \\
\hline & Metalurgia & 0,12 & 0,21 & $34^{\circ}$ \\
\hline & IF Tokamac adm & 0,13 & 0,21 & $30^{\circ}$ \\
\hline & Bienio & 0,10 & 0,19 & $41^{\circ}$ \\
\hline & FAU & 0,10 & 0,17 & $44^{\circ}$ \\
\hline & Biblioteca das Quimicas & 0,09 & 0,16 & $48^{\circ}$ \\
\hline \multirow{11}{*}{ Humanas } & Psicologia & 0,16 & 0,25 & $20^{\circ}$ \\
\hline & ECA Predios & 0,10 & 0,24 & $46^{\circ}$ \\
\hline & Creche Central & 0,15 & 0,24 & $22^{\circ}$ \\
\hline & FEA & 0,12 & 0,23 & $35^{\circ}$ \\
\hline & ECA Sintusp & 0,11 & 0,21 & $38^{\circ}$ \\
\hline & Historia Geografia & 0,11 & 0,21 & $39^{\circ}$ \\
\hline & Educaçao Fisica & 0,13 & 0,21 & $33^{\circ}$ \\
\hline & Fazendaria & 0,10 & 0,20 & $45^{\circ}$ \\
\hline & Ciencias Sociais Letras & 0,10 & 0,20 & $42^{\circ}$ \\
\hline & FFLCH adm & 0,13 & 0,20 & $31^{\circ}$ \\
\hline & Faculdade Educaçao & 0,09 & 0,17 & $47^{\circ}$ \\
\hline \multirow{5}{*}{ Saude } & $\mathrm{HU}$ & 0,19 & 0,30 & $7^{0}$ \\
\hline & Veterinaria & 0,17 & 0,26 & $16^{\circ}$ \\
\hline & Farmacia 13a 13b & 0,15 & 0,23 & $24^{\circ}$ \\
\hline & Farmacia 1317 & 0,14 & 0,22 & $29^{\circ}$ \\
\hline & Odonto & 0,12 & 0,21 & $36^{\circ}$ \\
\hline \multirow{4}{*}{ Biologicas } & ICB 4 & 0,19 & 0,32 & $6^{0}$ \\
\hline & ICB 2 & 0,18 & 0,28 & $11^{0}$ \\
\hline & ICB 1 & 0,17 & 0,26 & $14^{\circ}$ \\
\hline & Inst Oceanografico & 0,14 & 0,22 & $25^{\circ}$ \\
\hline \multirow{3}{*}{ Administrativa } & PCO & 0,20 & 0,33 & $5^{0}$ \\
\hline & CCE & 0,22 & 0,33 & $3^{\circ}$ \\
\hline & Reitoria & 0,10 & 0,16 & $43^{\circ}$ \\
\hline \multirow{2}{*}{ Residenciais } & CRUSP B & 0,19 & 0,33 & $8^{\circ}$ \\
\hline & CRUSP G & 0,15 & 0,27 & $21^{\circ}$ \\
\hline \multirow{2}{*}{ Lazer e Cultura } & MAC & 0,21 & 0,36 & $4^{0}$ \\
\hline & CEPE Quadras & 0,12 & 0,25 & $37^{\circ}$ \\
\hline \multirow{2}{*}{ Outras } & Galpoes Provisorios & 0,14 & 0,22 & $28^{\circ}$ \\
\hline & Banco Real & 0,11 & 0,18 & $40^{\circ}$ \\
\hline
\end{tabular}




\subsection{Classificação - Indicador por Usuários da Energia}

A classificação por consumo de energia por usuários considerou as informações do anuário estatístico da universidade e a somatória das áreas de especialidade, divididos em dois períodos distintos, ou seja, letivo e férias escolares.

Primeiramente as áreas foram classificadas de maneira geral por ordem decrescente de acordo com os resultados obtidos e, em seguida, utilizou-se a classificação prévia para comparar e identificar possíveis similaridades no comportamento do consumo por este indicador.

TABELA 12: CLASSIFICAÇÃO POR USUÁRIOS DA ENERGIA - GERAL

\begin{tabular}{|c|c|c|c|c|c|c|c|c|}
\hline & $\begin{array}{c}\text { Consumo } \\
\text { Periodo } \\
\text { Férias } \\
\text { (kWh/mês) }\end{array}$ & $\begin{array}{l}\text { Desvio } \\
\text { Padrão }\end{array}$ & $\begin{array}{c}\text { Consumo } \\
\text { Periodo } \\
\text { Letivo } \\
\text { (kWh/mês) }\end{array}$ & $\begin{array}{l}\text { Desvio } \\
\text { Padrão }\end{array}$ & $\begin{array}{l}\text { Total de } \\
\text { Usuarios }\end{array}$ & $\begin{array}{c}\text { kWh/usuario } \\
\text { Férias }\end{array}$ & $\begin{array}{c}\text { kWh/usuario } \\
\text { Letivo }\end{array}$ & Prioridade \\
\hline Museu de Arte Contemporânea & $120.725,74$ & $8 \%$ & $117.926,10$ & $12 \%$ & 99 & $1.219,45$ & $1.191,17$ & $1^{0}$ \\
\hline Centro de Computação Eletronica & $157.925,19$ & $17 \%$ & $160.192,47$ & $12 \%$ & 224 & 705,02 & 715,14 & $2^{\circ}$ \\
\hline Hospital Universitario/ICB & $1.005 .962,21$ & $4 \%$ & $1.052 .245,03$ & $7 \%$ & 3.263 & 308,29 & 322,48 & $3^{\circ}$ \\
\hline Instituto Oceanografico & $77.763,63$ & $7 \%$ & $82.640,25$ & $10 \%$ & 538 & 144,54 & 153,61 & $4^{\circ}$ \\
\hline Instituto de Geociência & $114.661,46$ & $7 \%$ & $123.903,33$ & $11 \%$ & 827 & 138,65 & 149,82 & $5^{\circ}$ \\
\hline Instituto de Astronomia e Geociência & $96.436,64$ & $9 \%$ & $105.920,98$ & $9 \%$ & 711 & 135,64 & 148,97 & $6^{\circ}$ \\
\hline Faculdade de Med. Veterinária e Zootecnia & $196.878,03$ & $9 \%$ & $200.964,78$ & $11 \%$ & 1.417 & 138,94 & 141,82 & $7^{\circ}$ \\
\hline Instituto de Química & $211.265,46$ & $8 \%$ & $206.111,86$ & $20 \%$ & 1.572 & 134,39 & 131,11 & $8^{\circ}$ \\
\hline Prefeitura & $58.671,46$ & $5 \%$ & $55.922,01$ & $15 \%$ & 429 & 136,76 & 130,35 & $9^{\circ}$ \\
\hline Faculdade de Ciencias Farmacêuticas & $143.901,09$ & $10 \%$ & $150.987,44$ & $10 \%$ & 1.758 & 81,85 & 85,89 & $10^{\circ}$ \\
\hline Faculdade de Odontologia & $100.425,49$ & $13 \%$ & $130.664,29$ & $13 \%$ & 1.572 & 63,88 & 83,12 & $11^{\circ}$ \\
\hline Reitoria & $77.818,54$ & $12 \%$ & $83.590,40$ & $11 \%$ & 1.047 & 74,33 & 79,84 & $12^{\circ}$ \\
\hline Escola Politécnica & $\overline{-}$ & - & $668.245,34$ & $6 \%$ & 9.848 & - & 67,86 & $13^{\circ}$ \\
\hline Escola de Educação Fisica & $37.993,62$ & $7 \%$ & $45.901,26$ & $13 \%$ & 947 & 40,12 & 48,47 & $14^{\circ}$ \\
\hline Instituto de Matemática e Estatística & $112.638,75$ & $14 \%$ & $123.447,20$ & $13 \%$ & 2.903 & 38,80 & 42,52 & $15^{\circ}$ \\
\hline Faculdade de Economia e Administração & $150.585,40$ & $15 \%$ & $181.649,27$ & $18 \%$ & 4.417 & 34,09 & 41,13 & $16^{\circ}$ \\
\hline Instituto de Psicologia & $32.947,67$ & $16 \%$ & $40.374,83$ & $15 \%$ & 1.445 & 22,80 & 27,94 & $17^{\circ}$ \\
\hline Faculdade de Educação & $46.696,65$ & $9 \%$ & $63.766,78$ & $14 \%$ & 2.514 & 18,57 & 25,36 & $18^{\circ}$ \\
\hline Faculdade de Arquitetura e Urbanismo & $49.390,85$ & $11 \%$ & $58.667,36$ & $16 \%$ & 2.533 & 19,50 & 23,16 & $19^{\circ}$ \\
\hline Escola de Comunicação e Artes & $53.944,01$ & $5 \%$ & $64.787,22$ & $14 \%$ & 3.837 & 14,06 & 16,88 & $20^{\circ}$ \\
\hline CUASO & $5.435 .224,82$ & $5 \%$ & $5.908 .362,08$ & $9 \%$ & 67.057 & 81,05 & 88,11 & \\
\hline
\end{tabular}


TABELA 13: CLASSIFICAÇÃO POR USUÁRIOS DA ENERGIA - ESPECIALIDADE/ATIVIDADE

\begin{tabular}{|c|c|c|c|c|c|c|c|c|c|}
\hline & & $\begin{array}{c}\text { Consumo } \\
\text { Periodo } \\
\text { Férias } \\
\text { (kWh/mês) }\end{array}$ & $\begin{array}{l}\text { Desvio } \\
\text { Padrão }\end{array}$ & $\begin{array}{c}\text { Consumo } \\
\text { Periodo } \\
\text { Letivo } \\
\text { (kWh/mês) }\end{array}$ & \begin{tabular}{|} 
Desvio \\
Padrão
\end{tabular} & $\left|\begin{array}{l}\text { Total de } \\
\text { Usuarios }\end{array}\right|$ & $\begin{array}{c}\text { kWh/usuario } \\
\text { Férias }\end{array}$ & $\begin{array}{c}\mathrm{kWh} / \text { usuario } \\
\text { Letivo }\end{array}$ & Prioridade \\
\hline \multirow{6}{*}{ Exatas } & Instituto de Geociência & $114.661,46$ & $7 \%$ & $123.903,33$ & $11 \%$ & 827 & 138,65 & 149,82 & $5^{\circ}$ \\
\hline & Instituto de Astronomia e Geociência & $96.436,64$ & $9 \%$ & $105.920,98$ & $9 \%$ & 711 & 135,64 & 148,97 & $6^{\circ}$ \\
\hline & Instituto de Química & $211.265,46$ & $8 \%$ & $206.111,86$ & $20 \%$ & 1.572 & 134,39 & 131,11 & $8^{\circ}$ \\
\hline & Escola Politécnica & & - & $668.245,34$ & $6 \%$ & 9.848 & - & 67,86 & $13^{\circ}$ \\
\hline & Instituto de Matemática e Estatística & $112.638,75$ & $14 \%$ & $123.447,20$ & $13 \%$ & 2.903 & 38,80 & 42,52 & $15^{\circ}$ \\
\hline & Faculdade de Arquitetura e Urbanismo & $49.390,85$ & $11 \%$ & $58.667,36$ & $16 \%$ & 2.533 & 19,50 & 23,16 & $19^{\circ}$ \\
\hline \multirow{5}{*}{ Humanas } & Escola de Educação Fisica & $37.993,62$ & $7 \%$ & $45.901,26$ & $13 \%$ & 947 & 40,12 & 48,47 & $14^{\circ}$ \\
\hline & Faculdade de Economia e Administração & $150.585,40$ & $15 \%$ & $181.649,27$ & $18 \%$ & 4.417 & 34,09 & 41,13 & $16^{\circ}$ \\
\hline & Instituto de Psicologia & $32.947,67$ & $16 \%$ & $40.374,83$ & $15 \%$ & 1.445 & 22,80 & 27,94 & $17^{\circ}$ \\
\hline & Faculdade de Educação & $46.696,65$ & $9 \%$ & $63.766,78$ & $14 \%$ & 2.514 & 18,57 & 25,36 & $18^{\circ}$ \\
\hline & Escola de Comunicação e Artes & $53.944,01$ & $5 \%$ & $64.787,22$ & $14 \%$ & 3.837 & 14,06 & 16,88 & $20^{\circ}$ \\
\hline Biológicas & Instituto Oceanografico & $77.763,63$ & $7 \%$ & $82.640,25$ & $10 \%$ & 538 & 144,54 & 153,61 & $4^{\circ}$ \\
\hline \multirow{4}{*}{ Saude } & Hospital Universitario/ICB & $1.005 .962,21$ & $4 \%$ & $1.052 .245,03$ & $7 \%$ & 3.263 & 308,29 & 322,48 & $3^{\circ}$ \\
\hline & Faculdade de Med. Veterinária e Zootecnia & $196.878,03$ & $9 \%$ & $200.964,78$ & $11 \%$ & 1.417 & 138,94 & 141,82 & $7^{\circ}$ \\
\hline & Faculdade de Ciencias Farmacêuticas & $143.901,09$ & $10 \%$ & $150.987,44$ & $10 \%$ & 1.758 & 81,85 & 85,89 & $10^{\circ}$ \\
\hline & Faculdade de Odontologia & $100.425,49$ & $13 \%$ & $130.664,29$ & $13 \%$ & 1.572 & 63,88 & 83,12 & $11^{\circ}$ \\
\hline \multirow{3}{*}{ Administrativa } & Centro de Computação Eletronica & $157.925,19$ & $17 \%$ & $160.192,47$ & $12 \%$ & 224 & 705,02 & 715,14 & $2^{\circ}$ \\
\hline & Prefeitura & $58.671,46$ & $5 \%$ & $55.922,01$ & $15 \%$ & 429 & 136,76 & 130,35 & $9^{\circ}$ \\
\hline & Reitoria & $77.818,54$ & $12 \%$ & $83.590,40$ & $11 \%$ & 1.047 & 74,33 & 79,84 & $12^{\circ}$ \\
\hline \multirow[t]{2}{*}{ Lazer e Cultura } & Museu de Arte Contemporânea & $120.725,74$ & $8 \%$ & $117.926,10$ & $12 \%$ & 99 & $1.219,45$ & $1.191,17$ & $1^{\circ}$ \\
\hline & CUASO & $5.435 .224,82$ & $5 \%$ & $5.908 .362,08$ & $9 \%$ & 67.057 & 81,05 & 88,11 & \\
\hline
\end{tabular}

\subsection{Classificação - Indicador por área edificada}

De maneira análoga ao indicador por usuário da energia, a classificação por área edificada considerou os períodos letivos e férias escolares, baseando-se nas informações de área edificada obtidas através do anuário estatístico da universidade.

TABELA 14: CLASSIFICAÇ̃̃o POR ÁREA EDIFICADA - GERAL

\begin{tabular}{|c|c|c|c|c|c|c|c|c|}
\hline & $\begin{array}{l}\text { Consumo } \\
\text { Periodo } \\
\text { Férias } \\
\text { (kWh/mês) }\end{array}$ & $\begin{array}{l}\text { Desvio } \\
\text { Padrão }\end{array}$ & $\begin{array}{l}\text { Consumo } \\
\text { Periodo } \\
\text { Letivo } \\
\text { (kWh/mês) }\end{array}$ & $\begin{array}{l}\text { Desvio } \\
\text { Padrão }\end{array}$ & $\begin{array}{c}\text { Area } \\
\text { Edificada } \\
\text { (m2) }\end{array}$ & $\begin{array}{c}\mathrm{kWh} / \mathrm{m} 2 \\
\text { Férias }\end{array}$ & $\begin{array}{c}\mathrm{kWh} / \mathrm{m} 2 \\
\text { Letivo }\end{array}$ & Prioridade \\
\hline Centro de Computação Eletronica & $157.925,19$ & $17 \%$ & $160.192,47$ & $12 \%$ & 4.337 & 36,42 & 36,94 & $1^{\circ}$ \\
\hline Hospital Universitario/ICB & $1.005 .962,21$ & $4 \%$ & $1.052 .245,03$ & $7 \%$ & 85.187 & 11,81 & 12,35 & $2^{\circ}$ \\
\hline Museu de Arte Contemporânea & $120.725,74$ & $8 \%$ & $117.926,10$ & $12 \%$ & 11.071 & 10,90 & 10,65 & $3^{\circ}$ \\
\hline Instituto de Matemática e Estatística & $112.638,75$ & $14 \%$ & $123.447,20$ & $13 \%$ & 14.609 & 7,71 & 8,45 & $4^{\circ}$ \\
\hline Faculdade de Ciencias Farmacêuticas & $143.901,09$ & $10 \%$ & $150.987,44$ & $10 \%$ & 19.041 & 7,56 & 7,93 & $5^{\circ}$ \\
\hline Instituto de Geociência & $114.661,46$ & $7 \%$ & $123.903,33$ & $11 \%$ & 16.495 & 6,95 & 7,51 & $6^{\circ}$ \\
\hline Faculdade de Med. Veterinária e Zootecnia & $196.878,03$ & $9 \%$ & $200.964,78$ & $11 \%$ & 32.033 & 6,15 & 6,27 & $7^{\circ}$ \\
\hline Instituto de Astronomia e Geociência & $96.436,64$ & $9 \%$ & $105.920,98$ & $9 \%$ & 17.238 & 5,59 & 6,14 & $8^{\circ}$ \\
\hline Instituto de Química & $211.265,46$ & $8 \%$ & $206.111,86$ & $20 \%$ & 33.959 & 6,22 & 6,07 & $9^{\circ}$ \\
\hline Faculdade de Economia e Administração & $150.585,40$ & $15 \%$ & $181.649,27$ & $18 \%$ & 32.642 & 4,61 & 5,56 & $10^{\circ}$ \\
\hline Faculdade de Odontologia & $100.425,49$ & $13 \%$ & $130.664,29$ & $13 \%$ & 24.421 & 4,11 & 5,35 & $11^{\circ}$ \\
\hline Instituto Oceanografico & $77.763,63$ & $7 \%$ & $82.640,25$ & $10 \%$ & 15.699 & 4,95 & 5,26 & $12^{\circ}$ \\
\hline Escola de Educação Fisica & $37.993,62$ & $7 \%$ & $45.901,26$ & $13 \%$ & 10.124 & 3,75 & 4,53 & $13^{\circ}$ \\
\hline Escola Politécnica & - & - & $668.245,34$ & $6 \%$ & 154.190 & - & 4,33 & $14^{\circ}$ \\
\hline Faculdade de Educação & $46.696,65$ & $9 \%$ & $63.766,78$ & $14 \%$ & 22.616 & 2,06 & 2,82 & $15^{\circ}$ \\
\hline Instituto de Psicologia & $32.947,67$ & $16 \%$ & $40.374,83$ & $15 \%$ & 14.706 & 2,24 & 2,75 & $16^{\circ}$ \\
\hline Escola de Comunicação e Artes & $53.944,01$ & $5 \%$ & $64.787,22$ & $14 \%$ & 25.088 & 2,15 & 2,58 & $17^{\circ}$ \\
\hline Prefeitura & $58.671,46$ & $5 \%$ & $55.922,01$ & $15 \%$ & 21.938 & 2,67 & 2,55 & $18^{\circ}$ \\
\hline Faculdade de Arquitetura e Urbanismo & $49.390,85$ & $11 \%$ & $58.667,36$ & $16 \%$ & 24.524 & 2,01 & 2,39 & $19^{\circ}$ \\
\hline Reitoria & $77.818,54$ & $12 \%$ & $83.590,40$ & $11 \%$ & 52.394 & 1,49 & 1,60 & $20^{\circ}$ \\
\hline CUASO & $5.435 .224,82$ & $5 \%$ & $5.908 .362,08$ & $9 \%$ & 848.944 & 6,40 & 6,96 & \\
\hline
\end{tabular}


TABELA 15: CLASSIFICAÇÃO POR ÁREA EDIFICADA - ESPECIALIDADE/ATIVIDADE

\begin{tabular}{|c|c|c|c|c|c|c|c|c|c|}
\hline & & $\begin{array}{c}\text { Consumo } \\
\text { Periodo } \\
\text { Férias } \\
\text { (kWh/mês) }\end{array}$ & $\begin{array}{l}\text { Desvio } \\
\text { Padrão }\end{array}$ & $\begin{array}{c}\text { Consumo } \\
\text { Periodo } \\
\text { Letivo } \\
\text { (kWh/mês) }\end{array}$ & \begin{tabular}{|l|} 
Desvio \\
Padrão
\end{tabular} & $\begin{array}{c}\text { Area } \\
\text { Edificada } \\
\text { (m2) }\end{array}$ & $\begin{array}{c}\mathrm{kWh} / \mathrm{m} 2 \\
\text { Férias }\end{array}$ & $\begin{array}{c}\mathrm{kWh} / \mathrm{m} 2 \\
\text { Letivo }\end{array}$ & Prioridade \\
\hline \multirow{6}{*}{ Exatas } & Instituto de Matemática e Estatística & $112.638,75$ & $14 \%$ & $123.447,20$ & $13 \%$ & 14.609 & 7,71 & 8,45 & $4^{\circ}$ \\
\hline & Instituto de Geociência & $114.661,46$ & $7 \%$ & $123.903,33$ & $11 \%$ & 16.495 & 6,95 & 7,51 & $6^{\circ}$ \\
\hline & Instituto de Astronomia e Geociência & $96.436,64$ & $9 \%$ & $105.920,98$ & $9 \%$ & 17.238 & 5,59 & 6,14 & $8^{\circ}$ \\
\hline & Instituto de Química & $211.265,46$ & $8 \%$ & $206.111,86$ & $20 \%$ & 33.959 & 6,22 & 6,07 & $9^{\circ}$ \\
\hline & Escola Politécnica & -1 & -1 & $668.245,34$ & $6 \%$ & 154.190 & & 4,33 & $14^{\circ}$ \\
\hline & Faculdade de Arquitetura e Urbanismo & $49.390,85$ & $11 \%$ & $58.667,36$ & $16 \%$ & 24.524 & 2,01 & 2,39 & $19^{\circ}$ \\
\hline \multirow{5}{*}{ Humanas } & Faculdade de Economia e Administração & $150.585,40$ & $15 \%$ & $181.649,27$ & $18 \%$ & 32.642 & 4,61 & 5,56 & $10^{\circ}$ \\
\hline & Escola de Educação Fisica & $37.993,62$ & $7 \%$ & $45.901,26$ & $13 \%$ & 10.124 & 3,75 & 4,53 & $13^{\circ}$ \\
\hline & Faculdade de Educação & $46.696,65$ & $9 \%$ & $63.766,78$ & $14 \%$ & 22.616 & 2,06 & 2,82 & $15^{\circ}$ \\
\hline & Instituto de Psicologia & $32.947,67$ & $16 \%$ & $40.374,83$ & $15 \%$ & 14.706 & 2,24 & 2,75 & $16^{\circ}$ \\
\hline & Escola de Comunicação e Artes & $53.944,01$ & $5 \%$ & $64.787,22$ & $14 \%$ & 25.088 & 2,15 & 2,58 & $17^{\circ}$ \\
\hline Biológicas & Instituto Oceanografico & $77.763,63$ & $7 \%$ & $82.640,25$ & $10 \%$ & 15.699 & 4,95 & 5,26 & $12^{\circ}$ \\
\hline \multirow{4}{*}{ Saude } & Hospital Universitario/ICB & $1.005 .962,21$ & $4 \%$ & $1.052 .245,03$ & $7 \%$ & 85.187 & 11,81 & 12,35 & $2^{\circ}$ \\
\hline & Faculdade de Ciencias Farmacêuticas & $143.901,09$ & $10 \%$ & $150.987,44$ & $10 \%$ & 19.041 & 7,56 & 7,93 & $5^{\circ}$ \\
\hline & Faculdade de Med. Veterinária e Zootecnia & $196.878,03$ & $9 \%$ & $200.964,78$ & $11 \%$ & 32.033 & 6,15 & 6,27 & $7^{\circ}$ \\
\hline & Faculdade de Odontologia & $100.425,49$ & $13 \%$ & $130.664,29$ & $13 \%$ & 24.421 & 4,11 & 5,35 & $11^{\circ}$ \\
\hline \multirow{3}{*}{ Administrativa } & Centro de Computação Eletronica & $157.925,19$ & $17 \%$ & $160.192,47$ & $12 \%$ & 4.337 & 36,42 & 36,94 & $1^{0}$ \\
\hline & Prefeitura & $58.671,46$ & $5 \%$ & $55.922,01$ & $15 \%$ & 21.938 & 2,67 & 2,55 & $18^{\circ}$ \\
\hline & Reitoria & $77.818,54$ & $12 \%$ & $83.590,40$ & $11 \%$ & 52.394 & 1,49 & 1,60 & $20^{\circ}$ \\
\hline \multirow[t]{2}{*}{ Lazer e Cultura } & Museu de Arte Contemporânea & $120.725,74$ & $8 \%$ & $117.926,10$ & $12 \%$ & 11.071 & 10,90 & 10,65 & $3^{\circ}$ \\
\hline & CUASO & $5.435 .224,82$ & $5 \%$ & $5.908 .362,08$ & $9 \%$ & 848.944 & 6,40 & 6,96 & \\
\hline
\end{tabular}

\subsection{Classificação - Indicador por Uso Final - Sistemas de refrigeração e ar condicionado}

A classificação por indicador específico em sistemas de refrigeração e ar condicionado considera as informações de temperatura extraídas de ROSA, L. H. L., 2007, dissertação de mestrado que desenvolve um sistema de apoio à gestão de utilidades e energia utilizando entre outras informações, a temperatura ambiente registrada na CUASO pelo Instituto de Astronomia e Geofísica da USP.

Para classificar as unidades consideradas no estudo de caso, adotou-se uma estimativa de consumo de energia elétrica neste uso final, a partir de temperaturas acima de $22^{\circ} \mathrm{C}$. A temperatura adotada tem como base os trabalhos MINAKI e AMORIM, 2004 e AGUAS, 2001, que citam as diversas variáveis consideradas nos cálculos de conforto térmico, inclusive a faixa de temperatura para conforto térmico da maioria das pessoas e, os resultados obtidos em SAIDEL et. al. 2006 que demonstram aumentos significativos na demanda máxima para cada grau aumento, a partir de $23^{\circ} \mathrm{C}$ de temperatura. 
A estimativa adotada certamente não abrangerá todas as aplicações de ar condicionado e refrigeração, pois a utilização desses sistemas não está associada somente à temperatura ambiente, no entanto, possibilitará a avaliação de comportamentos do consumo de energia elétrica em relação à temperatura e, eventualmente identificar potenciais de economia de recursos.

Utilizaram-se nas aplicações três meses com características distintas do ano de 2005, sendo o mês de Janeiro, período de férias da universidade, o mês de março, por ser um mês letivo e com temperaturas mais elevadas e, o mês de junho, por ser um mês letivo e com temperaturas mais baixas.

Para estimar o consumo de energia elétrica a partir da temperatura, utilizou-se a média de consumo diário dos dias úteis e não úteis com temperaturas abaixo dos $22^{\circ} \mathrm{C}$ e comparou-se ao consumo diário dos dias com temperaturas superiores a $22^{\circ} \mathrm{C}$, somando-se as diferenças encontradas.

Inicialmente o resultado em termos percentuais foi utilizado para elaborar a lista de prioridades de maneira decrescente e, logo após, aplicou-se os indicadores por usuários e área edificada para caracterizar as unidades pelo consumo em sistemas de refrigeração e ar condicionado a partir das informações físicas e de ocupação. 
TABELA 16: ClASSIFICAÇÃO POR USO FINAL: AR CONDICIONADO E REFRIGERAÇÃO

\begin{tabular}{|c|c|c|c|c|c|c|c|c|c|c|}
\hline \multirow[b]{2}{*}{ Unidades } & \multicolumn{3}{|c|}{ Janeiro } & \multicolumn{3}{|c|}{ Março } & \multicolumn{3}{|c|}{ Junho } & \multirow[b]{2}{*}{ Prioridade } \\
\hline & $\begin{array}{c}\text { Consumo Total } \\
\text { (kWh) }\end{array}$ & $\begin{array}{c}\text { Consumo } \\
\text { acima } 22^{\circ} \mathrm{C} \\
(\mathrm{kWh})\end{array}$ & $\begin{array}{c}\% \text { do total } \\
\text { unidades }\end{array}$ & $\begin{array}{c}\text { Consumo Total } \\
\text { (kWh) }\end{array}$ & $\begin{array}{c}\text { Consumo } \\
\text { acima } 22^{\circ} \mathrm{C} \\
(\mathrm{kWh})\end{array}$ & $\begin{array}{l}\% \text { do total } \\
\text { unidades }\end{array}$ & $\begin{array}{c}\text { Consumo Total } \\
\text { (kWh) }\end{array}$ & $\begin{array}{c}\text { Consumo } \\
\text { acima } 22^{\circ} \mathrm{C} \\
(\mathrm{kWh})\end{array}$ & $\begin{array}{c}\% \text { do total } \\
\text { unidades }\end{array}$ & \\
\hline Fazendaria & $12.647,50$ & $2.013,71$ & $16 \%$ & $28.220,11$ & $11.062,60$ & $39 \%$ & $12.113,26$ & $2.640,72$ & $22 \%$ & $1^{0}$ \\
\hline FEA & $127.908,05$ & $20.210,13$ & $16 \%$ & $205.947,08$ & $68.080,84$ & $33 \%$ & $122.090,58$ & $14.752,01$ & $12 \%$ & $2^{\circ}$ \\
\hline Faculdade Educaçao & $42.266,92$ & $8.408,35$ & $20 \%$ & $64.814,02$ & $17.406,12$ & $27 \%$ & $40.460,88$ & $7.245,62$ & $18 \%$ & $3^{\circ}$ \\
\hline Odonto & $82.218,97$ & $7.285,33$ & $9 \%$ & $135.063,74$ & $35.716,73$ & $26 \%$ & $78.297,09$ & $11.790,25$ & $15 \%$ & $4^{\circ}$ \\
\hline Reitoria & $73.648,73$ & $13.863,49$ & $19 \%$ & $90.354,76$ & $23.853,07$ & $26 \%$ & $70.677,19$ & $7.763,74$ & $11 \%$ & $5^{\circ}$ \\
\hline Educaçao Fisica & $39.945,26$ & $6.901,11$ & $17 \%$ & $55.096,33$ & $14.478,73$ & $26 \%$ & $38.352,04$ & $3.680,97$ & $10 \%$ & $6^{\circ}$ \\
\hline Ciencias Sociais Letras & $81.565,94$ & $17.324,80$ & $21 \%$ & $100.936,18$ & $25.578,74$ & $25 \%$ & 78.876,88 & $7.411,85$ & $9 \%$ & $7^{\circ}$ \\
\hline FAU & $50.813,99$ & $8.095,57$ & $16 \%$ & $61.204,94$ & $15.468,80$ & $25 \%$ & $48.673,88$ & $7.089,74$ & $15 \%$ & $8^{\circ}$ \\
\hline Poli Naval & $102.992,85$ & $12.612,74$ & $12 \%$ & $137.953,01$ & $32.781,11$ & $24 \%$ & $98.966,14$ & $7.624,72$ & $8 \%$ & $9^{\circ}$ \\
\hline CEPE Quadras & $22.329,85$ & $2.239,41$ & $10 \%$ & $33.150,17$ & $7.687,00$ & $23 \%$ & $21.400,35$ & $2.451,58$ & $11 \%$ & $10^{\circ}$ \\
\hline Farmacia 13a 13b & $39.865,85$ & $4.831,48$ & $12 \%$ & $49.468,74$ & $11.207,48$ & $23 \%$ & $38.176,47$ & $3.068,89$ & $8 \%$ & $11^{\circ}$ \\
\hline Poli Quimica & $22.275,78$ & $2.320,83$ & $10 \%$ & $29.590,56$ & $6.579,44$ & $22 \%$ & $21.412,01$ & $2.429,14$ & $11 \%$ & $12^{\circ}$ \\
\hline Historia Geografia & $51.480,43$ & $9.442,17$ & $18 \%$ & $54.884,68$ & $12.193,46$ & $22 \%$ & $49.792,73$ & $3.868,37$ & $8 \%$ & $13^{\circ}$ \\
\hline Psicologia & $26.853,34$ & $3.159,94$ & $12 \%$ & $35.608,72$ & $7.858,87$ & $22 \%$ & $25.689,15$ & $3.290,03$ & $13 \%$ & $14^{\circ}$ \\
\hline Poli Eletrica & $164.843,25$ & $19.564,48$ & $12 \%$ & $222.012,41$ & $47.933,23$ & $22 \%$ & $158.098,78$ & $13.921,95$ & $9 \%$ & $15^{\circ}$ \\
\hline Farmacia 1317 & $93.766,98$ & $11.361,88$ & $12 \%$ & $109.511,30$ & $21.744,22$ & $20 \%$ & $89.976,51$ & $7.048,79$ & $8 \%$ & $16^{\circ}$ \\
\hline Galpoes Provisorios & $67.032,31$ & $7.187,81$ & $11 \%$ & $96.700,56$ & $19.164,42$ & $20 \%$ & $63.970,16$ & $8.886,64$ & $14 \%$ & $17^{\circ}$ \\
\hline ICB 1 & $222.007,85$ & $22.071,97$ & $10 \%$ & $260.654,07$ & $48.231,24$ & $19 \%$ & $213.428,83$ & $22.861,01$ & $11 \%$ & $18^{\circ}$ \\
\hline Veterinaria & $206.644,92$ & $18.980,21$ & $9 \%$ & $236.191,16$ & $43.620,16$ & $18 \%$ & $198.705,64$ & $12.393,69$ & $6 \%$ & $19^{\circ}$ \\
\hline Inst Geociencias & $123.775,61$ & $7.138,91$ & $6 \%$ & $138.346,37$ & $24.601,16$ & $18 \%$ & $119.247,65$ & $7.413,17$ & $6 \%$ & $20^{\circ}$ \\
\hline Matematica & $130.611,92$ & $7.627,35$ & $6 \%$ & $135.573,93$ & $23.762,33$ & $18 \%$ & $125.478,64$ & $6.073,58$ & $5 \%$ & $21^{\circ}$ \\
\hline Biblioteca das Quimicas & $12.440,34$ & $1.750,41$ & $14 \%$ & $12.961,44$ & $2.096,06$ & $16 \%$ & $11.974,76$ & $1.017,91$ & $9 \%$ & $22^{\circ}$ \\
\hline ICB 2 & $208.736,38$ & $17.036,99$ & $8 \%$ & $238.816,01$ & $35.928,23$ & $15 \%$ & $200.748,52$ & $18.374,12$ & $9 \%$ & $23^{\circ}$ \\
\hline Quimica semi industrial & $41.411,08$ & $3.454,22$ & $8 \%$ & $52.026,92$ & $6.004,24$ & $12 \%$ & $39.927,24$ & $2.903,96$ & $7 \%$ & $24^{\circ}$ \\
\hline CCE & $167.499,81$ & $8.577,94$ & $5 \%$ & $180.174,72$ & $20.364,02$ & $11 \%$ & $151.561,95$ & $1.497,22$ & $1 \%$ & $25^{\circ}$ \\
\hline $\mathrm{HU}$ & $539.905,72$ & $28.258,31$ & $5 \%$ & $585.704,68$ & $56.920,87$ & $10 \%$ & $520.860,98$ & $16.919,34$ & $3 \%$ & $26^{\circ}$ \\
\hline MAC & $127.996,77$ & $6.732,25$ & $5 \%$ & $137.479,96$ & $9.309,56$ & $7 \%$ & $123.698,84$ & $3.673,43$ & $3 \%$ & $27^{\circ}$ \\
\hline CUASO & $5.439 .697,88$ & $1.007 .366,40$ & $19 \%$ & $7.355 .442,91$ & $1.373 .318,45$ & $19 \%$ & $5.230 .437,08$ & $315.904,73$ & $6 \%$ & \\
\hline
\end{tabular}

TABEla 17: ClassificaÇÃo POR Uso Final: Ar CONDICIONADO E REFrigERAÇão - ÁrEA EDIFICADA

\begin{tabular}{|c|c|c|c|c|c|c|c|c|}
\hline & Janeiro & Março & Junho & & Janeiro & Março & Junho & \\
\hline & $\begin{array}{l}\text { Consumo } \\
\text { (kWh/mês) }\end{array}$ & $\begin{array}{l}\text { Consumo } \\
\text { (kWh/mês) }\end{array}$ & $\begin{array}{l}\text { Consumo } \\
\text { (kWh/mês) }\end{array}$ & $\begin{array}{c}\text { Area } \\
\text { Edificada } \\
\text { Total (m2) }\end{array}$ & $\mathrm{kWh} / \mathrm{m} 2$ & $\mathrm{kWh} / \mathrm{m} 2$ & $\mathrm{kWh} / \mathrm{m} 2$ & Prioridade \\
\hline Centro de Computação Eletronica & $8.577,94$ & $20.364,02$ & $1.497,22$ & 4.337 & 1,98 & 4,70 & 0,35 & $1^{0}$ \\
\hline Faculdade de Economia e Administração & $22.223,83$ & $79.143,44$ & $17.392,74$ & 32.642 & 0,68 & 2,42 & 0,53 & $2^{\circ}$ \\
\hline Faculdade de Ciencias Farmacêuticas & $16.193,37$ & $32.951,69$ & $10.117,67$ & 19.041 & 0,85 & 1,73 & 0,53 & $3^{\circ}$ \\
\hline Hospital Universitario/ICB & $67.367,26$ & $141.080,34$ & $58.154,46$ & 85.187 & 0,79 & 1,66 & 0,68 & $4^{\circ}$ \\
\hline Instituto de Matemática e Estatística & $7.627,35$ & $23.762,33$ & $6.073,58$ & 14.609 & 0,52 & 1,63 & 0,42 & $5^{\circ}$ \\
\hline Instituto de Geociência & $7.138,91$ & $24.601,16$ & $7.413,17$ & 16.495 & 0,43 & 1,49 & 0,45 & $6^{\circ}$ \\
\hline Faculdade de Odontologia & $7.285,33$ & $35.716,73$ & $11.790,25$ & 24.421 & 0,30 & 1,46 & 0,48 & $7^{\circ}$ \\
\hline Escola de Educação Fisica & $6.901,11$ & $14.478,73$ & $3.680,97$ & 10.124 & 0,68 & 1,43 & 0,36 & $8^{\circ}$ \\
\hline Faculdade de Med. Veterinária e Zootecnia & $18.980,21$ & $43.620,16$ & $12.393,69$ & 32.033 & 0,59 & 1,36 & 0,39 & $9^{\circ}$ \\
\hline Museu de Arte Contemporânea & $6.732,25$ & $9.309,56$ & $3.673,43$ & 11.071 & 0,61 & 0,84 & 0,33 & $10^{\circ}$ \\
\hline Faculdade de Educação & $8.408,35$ & $17.406,12$ & $7.245,62$ & 22.616 & 0,37 & 0,77 & 0,32 & $11^{\circ}$ \\
\hline Faculdade de Arquitetura e Urbanismo & $8.095,57$ & $15.468,80$ & $7.089,74$ & 24.524 & 0,33 & 0,63 & 0,29 & $12^{\circ}$ \\
\hline Instituto de Psicologia & $3.159,94$ & $7.858,87$ & $3.290,03$ & 14.706 & 0,21 & 0,53 & 0,22 & $13^{\circ}$ \\
\hline Reitoria & $13.863,49$ & $23.853,07$ & $7.763,74$ & 52.394 & 0,26 & 0,46 & 0,15 & $14^{\circ}$ \\
\hline Instituto de Química & $5.204,62$ & $8.100,30$ & $3.921,88$ & 33.959 & 0,15 & 0,24 & 0,12 & $15^{\circ}$ \\
\hline CUASO & $1.007 .366,40$ & $1.373 .318,45$ & $315.904,73$ & 848.944 & 1,19 & 1,62 & 0,37 & \\
\hline
\end{tabular}

TABELA 18: ClASSIFICAÇ̃̃o POR USO FINAL: AR CONDICIONADO E REFRIGERAÇÃO - USUÁRIOS

\begin{tabular}{|c|c|c|c|c|c|c|c|c|}
\hline & Janeiro & Março & Junho & & Janeiro & Março & Junho & \\
\hline & $\begin{array}{l}\text { Consumo } \\
\text { (kWh/mês) }\end{array}$ & $\begin{array}{l}\text { Consumo } \\
\text { (kWh/mês) }\end{array}$ & $\begin{array}{c}\text { Consumo } \\
\text { (kWh/mês) }\end{array}$ & $\begin{array}{c}\text { Total de } \\
\text { Usuarios }\end{array}$ & kWh/us & kWh/us & kWh/us & Prioridade \\
\hline Museu de Arte Contemporânea & $6.732,25$ & $9.309,56$ & $3.673,43$ & 99 & 68,00 & 94,04 & 37,11 & $1^{0}$ \\
\hline Centro de Computação Eletronica & $8.577,94$ & $20.364,02$ & $1.497,22$ & 224 & 38,29 & 90,91 & 6,68 & $2^{\circ}$ \\
\hline Hospital Universitario/ICB & $67.367,26$ & $141.080,34$ & $58.154,46$ & 3.263 & 20,65 & 43,24 & 17,82 & $3^{\circ}$ \\
\hline Faculdade de Med. Veterinária e Zootecnia & $18.980,21$ & $43.620,16$ & $12.393,69$ & 1.417 & 13,39 & 30,78 & 8,75 & $4^{0}$ \\
\hline Instituto de Geociência & $7.138,91$ & $24.601,16$ & $7.413,17$ & 827 & 8,63 & 29,75 & 8,96 & $5^{\circ}$ \\
\hline Reitoria & $13.863,49$ & $23.853,07$ & $7.763,74$ & 1.047 & 13,24 & 22,78 & 7,42 & $6^{\circ}$ \\
\hline Faculdade de Odontologia & $7.285,33$ & $35.716,73$ & $11.790,25$ & 1.572 & 4,63 & 22,72 & 7,50 & $7^{\circ}$ \\
\hline Faculdade de Ciencias Farmacêuticas & $16.193,37$ & $32.951,69$ & $10.117,67$ & 1.758 & 9,21 & 18,74 & 5,76 & $8^{\circ}$ \\
\hline Faculdade de Economia e Administração & $22.223,83$ & $79.143,44$ & $17.392,74$ & 4.417 & 5,03 & 17,92 & 3,94 & $9^{\circ}$ \\
\hline Escola de Educação Fisica & $6.901,11$ & $14.478,73$ & $3.680,97$ & 947 & 7,29 & 15,29 & 3,89 & $10^{\circ}$ \\
\hline Instituto de Matemática e Estatística & $7.627,35$ & $23.762,33$ & $6.073,58$ & 2.903 & 2,63 & 8,19 & 2,09 & $11^{\circ}$ \\
\hline Faculdade de Educação & $8.408,35$ & $17.406,12$ & $7.245,62$ & 2.514 & 3,34 & 6,92 & 2,88 & $12^{\circ}$ \\
\hline Faculdade de Arquitetura e Urbanismo & $8.095,57$ & $15.468,80$ & $7.089,74$ & 2.533 & 3,20 & 6,11 & 2,80 & $13^{\circ}$ \\
\hline Instituto de Psicologia & $3.159,94$ & $7.858,87$ & $3.290,03$ & 1.445 & 2,19 & 5,44 & 2,28 & $14^{\circ}$ \\
\hline Instituto de Química & $5.204,62$ & $8.100,30$ & $3.921,88$ & 1.572 & 3,31 & 5,15 & 2,49 & $15^{\circ}$ \\
\hline CUASO & $1.007 .366,40$ & $1.373 .318,45$ & $315.904,73$ & 67.057 & 15,02 & 20,48 & 4,71 & \\
\hline
\end{tabular}




\subsection{Classificação - Indicador por Uso Final - Sistemas de iluminação}

Para utilizar a classificação por indicadores de uso final em sistemas de iluminação é necessária uma estimativa de consumo com este uso final. Um dos métodos utilizados para estimar o consumo de energia elétrica por uso final, porém, exige grande um "trabalho de campo", utiliza o levantamento da potência nominal, quantidade e horários de utilização dos equipamentos.

Sendo assim, baseando-se em informações atuais, utilizaram-se as informações do diagnóstico para substituição de equipamentos de iluminação no Instituto de Psicologia do projeto PUREFA. A estimativa em sistemas de iluminação foi comparada à média de consumo no período de janeiro de 2005 a outubro de 2006 e, os indicadores financeiros e área edificada foram aplicados para verificar a influência da iluminação nos custos da unidade e no consumo total por área.

TABELA 19: CLASSIFICAÇÃO POR USO FINAL: ILUMINAÇÃO

\begin{tabular}{|l|c|c|c|c|c|c|}
\hline & $\begin{array}{c}\text { Consumo } \\
\text { Médio } \\
\mathbf{( k W h / m e ̂ s )}\end{array}$ & $\begin{array}{c}\text { Consumo } \\
\text { Estimado } \\
\text { lluminação }(\mathbf{k W h})\end{array}$ & $\begin{array}{l}\text { \% consumo } \\
\text { lluminação }\end{array}$ & $\begin{array}{c}\text { Custo com } \\
\text { lluminação } \\
\text { (R\$) }\end{array}$ & $\begin{array}{c}\text { Area } \\
\text { Edificada } \\
\text { Total (m2) }\end{array}$ & $\begin{array}{c}\mathbf{R} \$ \mathbf{m} 2 \\
\text { Iluminação }\end{array}$ \\
\hline Instituto de Psicologia & 40.375 & 5.189 & $13 \%$ & 642,98 & 14.706 & 0,04 \\
\hline
\end{tabular}

\subsection{Classificação - Indicador por Uso Final - Equipamentos de informática}

A caracterização por indicadores de uso final em equipamentos de informática, como em qualquer outro uso final, necessita de uma estimativa do consumo. Sendo assim, utilizaram-se as informações do anuário estatístico da universidade, os horários médios de funcionamento e a potência nominal dos equipamentos. 
A estimativa contou apenas com as informações de quantidade de microcomputadores cadastrados no anuário, adotou-se 110 Watts como sendo a potência média dos equipamentos e a utilização média de 8 horas diárias.

Ao consumo estimado foram aplicados os indicadores de consumo e equipamentos por usuário e, em seguida, a classificação por prioridades foi realizada de maneira decrescente de acordo com os resultados. Visando auxiliar na comparação das similaridades, a separação por especialidades de acordo com a classificação prévia, também foi utilizada.

TABELA 20: ClASSIFICAÇÃo POR USO FINAL: EQUIPAMENTOS DE INFORMÁTICA - USUÁRIOS GERAL

\begin{tabular}{|l|c|c|c|c|c|c|}
\hline \multicolumn{1}{|l|}{} & $\begin{array}{c}\text { Total de } \\
\text { Usuarios }\end{array}$ & $\begin{array}{c}\text { Quantidade } \\
\text { Equipamentos }\end{array}$ & $\begin{array}{c}\text { Consumo } \\
\text { Estimado } \\
\text { (kWh) }\end{array}$ & Equip./Usuar. & kWh/Usuar. & Prioridade \\
\hline Centro de Computação Eletronica & 224 & 511 & $13.490,40$ & 2,28 & 60,23 & $1^{\circ}$ \\
\hline Instituto de Astronomia e Geociência & 711 & 798 & $21.067,20$ & 1,12 & 29,63 & $2^{\circ}$ \\
\hline Museu de Arte Contemporânea & 99 & 76 & $2.006,40$ & 0,77 & 20,27 & $3^{\circ}$ \\
\hline Instituto de Química & 1.572 & 742 & $19.588,80$ & 0,47 & 12,46 & $4^{\circ}$ \\
\hline Instituto de Geociência & 827 & 319 & $8.421,60$ & 0,39 & 10,18 & $5^{\circ}$ \\
\hline Reitoria & 1.047 & 392 & $10.348,80$ & 0,37 & 9,88 & $6^{\circ}$ \\
\hline Faculdade de Med. Veterinária e Zootecnia & 1.417 & 494 & $13.041,60$ & 0,35 & 9,20 & $7^{\circ}$ \\
\hline Prefeitura & 429 & 145 & $3.828,00$ & 0,34 & 8,92 & $8^{\circ}$ \\
\hline Hospital Universitario/ICB & 3.263 & 1.023 & $27.007,20$ & 0,31 & 8,28 & $9^{\circ}$ \\
\hline Instituto Oceanografico & 538 & 153 & $4.039,20$ & 0,28 & 7,51 & $10^{\circ}$ \\
\hline Escola Politécnica & 9.848 & 2.666 & $70.382,40$ & 0,27 & 7,15 & $11^{\circ}$ \\
\hline Faculdade de Ciencias Farmacêuticas & 1.758 & 425 & $11.220,00$ & 0,24 & 6,38 & $12^{\circ}$ \\
\hline Faculdade de Odontologia & 1.572 & 361 & $9.530,40$ & 0,23 & 6,06 & $13^{\circ}$ \\
\hline Instituto de Psicologia & 1.445 & 326 & $8.606,40$ & 0,23 & 5,96 & $14^{\circ}$ \\
\hline Instituto de Matemática e Estatística & 2.903 & 601 & $15.866,40$ & 0,21 & 5,47 & $15^{\circ}$ \\
\hline Escola de Educação Fisica & 947 & 196 & $5.174,40$ & 0,21 & 5,46 & $16^{\circ}$ \\
\hline Faculdade de Educação & 2.514 & 478 & $12.619,20$ & 0,19 & 5,02 & $17^{\circ}$ \\
\hline Faculdade de Arquitetura e Urbanismo & 2.533 & 407 & $10.744,80$ & 0,16 & 4,24 & $18^{\circ}$ \\
\hline Escola de Comunicação e Artes & 3.837 & 562 & $14.836,80$ & 0,15 & 3,87 & $19^{\circ}$ \\
\hline Faculdade de Economia e Administração & 4.417 & 358 & $9.451,20$ & 0,08 & 2,14 & $20^{\circ}$ \\
\hline CUASO & 67.057 & 15.416 & $406.982,40$ & 0,23 & 6,07 & \\
\hline
\end{tabular}


TABELA 21: CLASSIFICAÇÃO POR UsO FINAL: EQUIPAMENTOS DE INFORMÁTICA - UsUÁRIOS POR ESPECIALIDADE/ATIVIDADE

\begin{tabular}{|c|c|c|c|c|c|c|c|}
\hline & & $\begin{array}{l}\text { Total de } \\
\text { Usuarios }\end{array}$ & $\begin{array}{c}\text { Quantidade } \\
\text { Equipamentos }\end{array}$ & $\begin{array}{c}\text { Consumo } \\
\text { Estimado } \\
\text { (kWh) }\end{array}$ & Equip./Usuar. & kWh/Usuar. & Prioridade \\
\hline \multirow{6}{*}{ Exatas } & Instituto de Astronomia e Geociência & 711 & 798 & $21.067,20$ & 1,12 & 29,63 & $2^{\circ}$ \\
\hline & Instituto de Química & 1.572 & 742 & $19.588,80$ & 0,47 & 12,46 & $4^{\circ}$ \\
\hline & Instituto de Geociência & 827 & 319 & $8.421,60$ & 0,39 & 10,18 & $5^{\circ}$ \\
\hline & Escola Politécnica & 9.848 & 2.666 & $70.382,40$ & 0,27 & 7,15 & $11^{\circ}$ \\
\hline & Instituto de Matemática e Estatística & 2.903 & 601 & $15.866,40$ & 0,21 & 5,47 & $15^{\circ}$ \\
\hline & Faculdade de Arquitetura e Urbanismo & 2.533 & 407 & $10.744,80$ & 0,16 & 4,24 & $18^{\circ}$ \\
\hline \multirow{5}{*}{ Humanas } & Instituto de Psicologia & 1.445 & 326 & $8.606,40$ & 0,23 & 5,96 & $14^{\circ}$ \\
\hline & Escola de Educação Fisica & 947 & 196 & $5.174,40$ & 0,21 & 5,46 & $16^{\circ}$ \\
\hline & Faculdade de Educação & 2.514 & 478 & $12.619,20$ & 0,19 & 5,02 & $17^{\circ}$ \\
\hline & Escola de Comunicação e Artes & 3.837 & 562 & $14.836,80$ & 0,15 & 3,87 & $19^{\circ}$ \\
\hline & Faculdade de Economia e Administração & 4.417 & 358 & $9.451,20$ & 0,08 & 2,14 & $20^{\circ}$ \\
\hline Biológicas & Instituto Oceanografico & 538 & 153 & $4.039,20$ & 0,28 & 7,51 & $10^{\circ}$ \\
\hline \multirow{4}{*}{ Saude } & Faculdade de Med. Veterinária e Zootecnia & 1.417 & 494 & $13.041,60$ & 0,35 & 9,20 & $7^{0}$ \\
\hline & Hospital Universitario/ICB & 3.263 & 1.023 & $27.007,20$ & 0,31 & 8,28 & $9^{\circ}$ \\
\hline & Faculdade de Ciencias Farmacêuticas & 1.758 & 425 & $11.220,00$ & 0,24 & 6,38 & $12^{\circ}$ \\
\hline & Faculdade de Odontologia & 1.572 & 361 & $9.530,40$ & 0,23 & 6,06 & $13^{\circ}$ \\
\hline \multirow{3}{*}{ Administrativa } & Centro de Computação Eletronica & 224 & 511 & $13.490,40$ & 2,28 & 60,23 & $1^{0}$ \\
\hline & Reitoria & 1.047 & 392 & $10.348,80$ & 0,37 & 9,88 & $6^{\circ}$ \\
\hline & Prefeitura & 429 & 145 & $3.828,00$ & 0,34 & 8,92 & $8^{\circ}$ \\
\hline \multirow[t]{2}{*}{ Lazer e Cultura } & Museu de Arte Contemporânea & 99 & 76 & $2.006,40$ & 0,77 & 20,27 & $3^{\circ}$ \\
\hline & CUASO & 67.057 & 15.416 & $406.982,40$ & 0,23 & 6,07 & \\
\hline
\end{tabular}

\subsection{Classificação por indicador financeiro}

Os indicadores financeiros aplicados às informações de consumo de energia elétrica fazem uma ligação direta do consumo específico à participação nos custos totais pelo uso da energia.

Para classificar as unidades utilizando-se dos indicadores financeiros, adotaram-se apenas as informações de energia elétrica, desconsiderando a parcela pelo uso dos sistemas de transmissão e distribuição e as informações de penalidades por ultrapassagens e atrasos nos pagamentos.

Para verificar o custo da energia no período analisado, multiplicou-se o consumo mensal de energia elétrica da CUASO, aos preços de energia da área de concessão da AES Eletropaulo, obtidos através das resoluções homologatórias $n^{\circ}$ 165/2004, 147/2005 e 356/2006. Por possuir um contrato diferenciado, a CUASO, 
embora atendida em nível de tensão A2, foi submetida a preços do subgrupo A4 e tipo de tarifação convencional.

Para comparar os ambientes de contratação cativa e livre, adotou-se a média anual do Preço de Liquidação das Diferenças, o PLD, disponibilizado pela Câmara de Comercialização de Energia Elétrica, a CCEE, como contrato de energia para suprimento do consumo da CUASO. Esta comparação visa demonstrar o potencial de economia de recursos com a operação no ambiente de contratação livre, no entanto, os preços praticados atualmente no mercado livre apontam economias de apenas 10\%, aproximadamente, em relação ao ambiente cativo.

Inicialmente foram aplicados aos custos mensais com energia os indicadores por usuários e área edificada, nos dois ambientes de contratação, em seguida, verificaram-se os custos percentuais nos períodos letivos e férias escolares e aplicaram-se novamente os indicadores, ordenando as prioridades de forma decrescente, de acordo com os resultados obtidos. 
TABELA 22: INDICADORES FINANCEIROS: CUSTOS ENERGIA ELÉTRICA NA CUASO - UsuÁRIOS E ÁREA EdIFICADA

\begin{tabular}{|c|c|c|c|c|c|c|c|c|c|c|c|}
\hline Meses & $\begin{array}{c}\text { Consumo } \\
\text { (kWh) }\end{array}$ & $\begin{array}{c}\text { Preço } \\
\text { Cativo } \\
\text { (R\$/MWh) }\end{array}$ & $\begin{array}{c}\text { Total Cativo } \\
\text { (R\$) }\end{array}$ & $\begin{array}{c}\text { Preço Livre } \\
\text { (R\$/MWh) }\end{array}$ & $\begin{array}{l}\text { Total Livre } \\
\text { (R\$) }\end{array}$ & $\begin{array}{c}\text { Area } \\
\text { Edificada } \\
\text { Total (m2) }\end{array}$ & $\begin{array}{c}\text { Total } \\
\text { Usuarios }\end{array}$ & $\begin{array}{l}\mathrm{R} \$ / \mathrm{m} 2 \\
\text { Cativo }\end{array}$ & $\begin{array}{c}\mathrm{R} \$ / \mathrm{m} 2 \\
\text { Livre }\end{array}$ & $\begin{array}{c}\mathrm{R} \$ / \text { Usuar. } \\
\text { Cativo }\end{array}$ & $\begin{array}{c}\text { R\$/Usuar. } \\
\text { Livre }\end{array}$ \\
\hline jan/05 & $5.439 .697,88$ & 131,18 & $713.579,57$ & 28,88 & $157.080,34$ & 848.944 & 67.057 & 0,84 & 0,19 & 10,64 & 2,34 \\
\hline \begin{tabular}{|l|}
$\mathrm{fev} / 05$ \\
\end{tabular} & $5.247 .744,00$ & 131,18 & $688.399,06$ & 28,88 & $151.537,35$ & 848.944 & 67.057 & 0,81 & 0,18 & 10,27 & 2,26 \\
\hline mar/05 & $7.355 .442,91$ & 131,18 & $964.887,00$ & 28,88 & $212.400,67$ & 848.944 & 67.057 & 1,14 & 0,25 & 14,39 & 3,17 \\
\hline \begin{tabular}{|l|}
$a b r / 05$ \\
\end{tabular} & $5.714 .937,60$ & 131,18 & $749.685,51$ & 28,88 & $165.028,35$ & 848.944 & 67.057 & 0,88 & 0,19 & 11,18 & 2,46 \\
\hline mai/05 & $5.929 .036,80$ & 131,18 & $777.771,05$ & 28,88 & $171.210,82$ & 848.944 & 67.057 & 0,92 & 0,20 & 11,60 & 2,55 \\
\hline \begin{tabular}{|l|}
$j u n / 05$ \\
\end{tabular} & $5.230 .437,08$ & 131,18 & $686.128,74$ & 28,88 & $151.037,59$ & 848.944 & 67.057 & 0,81 & 0,18 & 10,23 & 2,25 \\
\hline \begin{tabular}{|l|}
$\mathrm{jul} / 05$ \\
\end{tabular} & $5.125 .751,04$ & 118,94 & $609.656,83$ & 28,88 & $148.014,60$ & 848.944 & 67.057 & 0,72 & 0,17 & 9,09 & 2,21 \\
\hline ago/05 & $5.904 .070,40$ & 118,94 & $702.230,13$ & 28,88 & $170.489,87$ & 848.944 & 67.057 & 0,83 & 0,20 & 10,47 & 2,54 \\
\hline set/05 & $5.417 .865,60$ & 118,94 & $644.400,93$ & 28,88 & $156.449,90$ & 848.944 & 67.057 & 0,76 & 0,18 & 9,61 & 2,33 \\
\hline \begin{tabular}{|l|} 
out $/ 05$ \\
\end{tabular} & $5.832 .902,40$ & 118,94 & $693.765,41$ & 28,88 & $168.434,78$ & 848.944 & 67.057 & 0,82 & 0,20 & 10,35 & 2,51 \\
\hline \begin{tabular}{|l|} 
nov/05 \\
\end{tabular} & $5.833 .140,30$ & 118,94 & $693.793,71$ & 28,88 & $168.441,65$ & 848.944 & 67.057 & 0,82 & 0,20 & 10,35 & 2,51 \\
\hline dez/05 & $5.303 .558,40$ & 118,94 & $630.805,24$ & 28,88 & $153.149,09$ & 848.944 & 67.057 & 0,74 & 0,18 & 9,41 & 2,28 \\
\hline jan/06 & $5.779 .219,20$ & 118,94 & $687.380,33$ & 66,81 & $386.092,30$ & 848.944 & 67.057 & 0,81 & 0,45 & 10,25 & 5,76 \\
\hline \begin{tabular}{|l|}
$\mathrm{fev} / 06$ \\
\end{tabular} & $5.841 .600,00$ & 118,94 & $694.799,90$ & 66,81 & $390.259,77$ & 848.944 & 67.057 & 0,82 & 0,46 & 10,36 & 5,82 \\
\hline mar/06 & $6.807 .984,00$ & 118,94 & $809.741,62$ & 66,81 & $454.820,99$ & 848.944 & 67.057 & 0,95 & 0,54 & 12,08 & 6,78 \\
\hline abr/06 & $5.808 .543,48$ & 118,94 & $690.868,16$ & 66,81 & $388.051,36$ & 848.944 & 67.057 & 0,81 & 0,46 & 10,30 & 5,79 \\
\hline mai/06 & $5.800 .407,65$ & 118,94 & $689.900,49$ & 66,81 & $387.507,83$ & 848.944 & 67.057 & 0,81 & 0,46 & 10,29 & 5,78 \\
\hline \begin{tabular}{|l|}
$j u n / 06$ \\
\end{tabular} & $5.281 .794,65$ & 118,94 & $628.216,66$ & 66,81 & $352.860,86$ & 848.944 & 67.057 & 0,74 & 0,42 & 9,37 & 5,26 \\
\hline \begin{tabular}{|l|}
$\mathrm{jul} / 06$ \\
\end{tabular} & $5.309 .003,24$ & 127,04 & $674.455,77$ & 66,81 & $354.678,58$ & 848.944 & 67.057 & 0,79 & 0,42 & 10,06 & 5,29 \\
\hline ago/06 & $6.057 .204,40$ & 127,04 & $769.507,25$ & 66,81 & $404.663,65$ & 848.944 & 67.057 & 0,91 & 0,48 & 11,48 & 6,03 \\
\hline set/06 & $5.579 .366,40$ & 127,04 & $708.802,71$ & 66,81 & $372.740,73$ & 848.944 & 67.057 & 0,83 & 0,44 & 10,57 & 5,56 \\
\hline out/06 & $6.072 .297,60$ & 127,04 & $771.424,69$ & 66,81 & $405.671,99$ & 848.944 & 67.057 & 0,91 & 0,48 & 11,50 & 6,05 \\
\hline
\end{tabular}

TABELA 23: INDICADORES FINANCEIROS: CUSTOS PERCENTUAIS POR UNIDADE - USUÁRIOS POR PERÍODO LETIVO E FÉRIAS

\begin{tabular}{|c|c|c|c|c|c|c|c|c|}
\hline & \begin{tabular}{|c|} 
Percentual do \\
consumo da \\
CUASO
\end{tabular} & $\begin{array}{c}\text { Participação } \\
\text { nos custos (R\$) }\end{array}$ & \begin{tabular}{|c|}
$\begin{array}{c}\text { Percentual do } \\
\text { consumo da } \\
\text { CUASO }\end{array}$ \\
\end{tabular} & \begin{tabular}{|c|} 
Participação \\
nos custos \\
(R\$)
\end{tabular} & $\begin{array}{l}\text { Total de } \\
\text { Usuarios }\end{array}$ & $\begin{array}{c}\text { R\$/usuario } \\
\text { Férias }\end{array}$ & $\begin{array}{c}\text { R\$/usuario } \\
\text { Letivo }\end{array}$ & Prioridade \\
\hline Museu de Arte Contemporânea & $2 \%$ & $14.910,66$ & $2 \%$ & $14.611,62$ & 99 & 150,61 & 147,59 & $1^{0}$ \\
\hline Centro de Computação Eletronica & $3 \%$ & $19.505,11$ & $3 \%$ & $19.848,63$ & 224 & 87,08 & 88,61 & $2^{\circ}$ \\
\hline Hospital Universitario/ICB & $19 \%$ & $124.244,92$ & $18 \%$ & $130.378,30$ & 3.263 & 38,08 & 39,96 & $3^{\circ}$ \\
\hline Instituto Oceanografico & $1 \%$ & $9.604,47$ & $1 \%$ & $10.239,53$ & 538 & 17,85 & 19,03 & $4^{0}$ \\
\hline Instituto de Geociência & $2 \%$ & $14.161,67$ & $2 \%$ & $15.352,23$ & 827 & 17,12 & 18,56 & $5^{\circ}$ \\
\hline Instituto de Astronomia e Geociência & $2 \%$ & $11.910,75$ & $2 \%$ & $13.124,13$ & 711 & 16,75 & 18,46 & $6^{\circ}$ \\
\hline Faculdade de Med. Veterinária e Zootecnia & $4 \%$ & $24.316,12$ & $3 \%$ & $24.900,52$ & 1.417 & 17,16 & 17,57 & $7^{\circ}$ \\
\hline Instituto de Química & $4 \%$ & $26.093,09$ & $3 \%$ & $25.538,27$ & 1.572 & 16,60 & 16,25 & $8^{\circ}$ \\
\hline Prefeitura & $1 \%$ & $7.246,43$ & $1 \%$ & $6.929,01$ & 429 & 16,89 & 16,15 & $9^{\circ}$ \\
\hline Faculdade de Ciencias Farmacêuticas & $3 \%$ & $17.773,01$ & $3 \%$ & $18.708,08$ & 1.758 & 10,11 & 10,64 & $10^{\circ}$ \\
\hline Faculdade de Odontologia & $2 \%$ & $12.403,41$ & $2 \%$ & $16.189,94$ & 1.572 & 7,89 & 10,30 & $11^{\circ}$ \\
\hline Reitoria & $1 \%$ & $9.611,25$ & $1 \%$ & $10.357,26$ & 1.047 & 9,18 & 9,89 & $12^{\circ}$ \\
\hline Escola Politécnica & - & - & $11 \%$ & $82.798,86$ & 9.848 & - & 8,41 & $13^{\circ}$ \\
\hline Escola de Educação Fisica & $1 \%$ & $4.692,54$ & $1 \%$ & $5.687,39$ & 947 & 4,96 & 6,01 & $14^{\circ}$ \\
\hline Instituto de Matemática e Estatística & $2 \%$ & $13.911,85$ & $2 \%$ & $15.295,71$ & 2.903 & 4,79 & 5,27 & $15^{\circ}$ \\
\hline Faculdade de Economia e Administração & $3 \%$ & $18.598,58$ & $3 \%$ & $22.507,23$ & 4.417 & 4,21 & 5,10 & $16^{\circ}$ \\
\hline Instituto de Psicologia & $1 \%$ & $4.069,32$ & $1 \%$ & $5.002,64$ & 1.445 & 2,82 & 3,46 & $17^{\circ}$ \\
\hline Faculdade de Educação & $1 \%$ & $5.767,44$ & $1 \%$ & $7.901,02$ & 2.514 & 2,29 & 3,14 & $18^{\circ}$ \\
\hline Faculdade de Arquitetura e Urbanismo & $1 \%$ & $6.100,19$ & $1 \%$ & $7.269,17$ & 2.533 & 2,41 & 2,87 & $19^{\circ}$ \\
\hline Escola de Comunicação e Artes & $1 \%$ & $6.662,55$ & $1 \%$ & $8.027,45$ & 3.837 & 1,74 & 2,09 & $20^{\circ}$ \\
\hline CUASO & $100 \%$ & $671.296,67$ & $100 \%$ & $732.074,94$ & 67.057 & 10,01 & 10,92 & \\
\hline
\end{tabular}


TABELA 24: INDICADORES FINANCEIROS: CUSTOS PERCENTUAIS POR UNIDADE - ÁREA EDIFICADA POR PERÍODO LETIVO E FÉRIAS

\begin{tabular}{|c|c|c|c|c|c|c|c|c|}
\hline & $\begin{array}{l}\text { Percentual do } \\
\text { consumo da } \\
\text { CUASO - Férias }\end{array}$ & $\begin{array}{c}\text { Participação } \\
\text { nos custos } \\
\text { (R\$) }\end{array}$ & $\begin{array}{l}\text { Percentual do } \\
\text { consumo da } \\
\text { CUASO - Letivo }\end{array}$ & $\begin{array}{c}\text { Participação } \\
\text { nos custos } \\
\text { (R\$) }\end{array}$ & $\begin{array}{c}\text { Area } \\
\text { Edificada } \\
\text { Total (m2) }\end{array}$ & $\begin{array}{l}\mathrm{R} \$ / \mathrm{m} 2 \\
\text { Férias }\end{array}$ & $\begin{array}{l}\mathrm{R} \$ / \mathrm{m} 2 \\
\text { Letivo }\end{array}$ & Prioridade \\
\hline Centro de Computação Eletronica & $3 \%$ & $19.505,11$ & $3 \%$ & $19.848,63$ & 4.337 & 4,50 & 4,58 & $1^{0}$ \\
\hline Hospital Universitario/ICB & $19 \%$ & $124.244,92$ & $18 \%$ & $130.378,30$ & 85.187 & 1,46 & 1,53 & $2^{\circ}$ \\
\hline Museu de Arte Contemporânea & $2 \%$ & $14.910,66$ & $2 \%$ & $14.611,62$ & 11.071 & 1,35 & 1,32 & $3^{0}$ \\
\hline Instituto de Matemática e Estatística & $2 \%$ & $13.911,85$ & $2 \%$ & $15.295,71$ & 14.609 & 0,95 & 1,05 & $4^{\circ}$ \\
\hline Faculdade de Ciencias Farmacêuticas & $3 \%$ & $17.773,01$ & $3 \%$ & $18.708,08$ & 19.041 & 0,93 & 0,98 & $5^{\circ}$ \\
\hline Instituto de Geociência & $2 \%$ & $14.161,67$ & $2 \%$ & $15.352,23$ & 16.495 & 0,86 & 0,93 & $6^{\circ}$ \\
\hline Faculdade de Med. Veterinária e Zootecnia & $4 \%$ & $24.316,12$ & $3 \%$ & $24.900,52$ & 32.033 & 0,76 & 0,78 & $7^{\circ}$ \\
\hline Instituto de Astronomia e Geociência & $2 \%$ & $11.910,75$ & $2 \%$ & $13.124,13$ & 17.238 & 0,69 & 0,76 & $8^{\circ}$ \\
\hline Instituto de Química & $4 \%$ & $26.093,09$ & $3 \%$ & $25.538,27$ & 33.959 & 0,77 & 0,75 & $9^{\circ}$ \\
\hline Faculdade de Economia e Administração & $3 \%$ & $18.598,58$ & $3 \%$ & $22.507,23$ & 32.642 & 0,57 & 0,69 & $10^{\circ}$ \\
\hline Faculdade de Odontologia & $2 \%$ & $12.403,41$ & $2 \%$ & $16.189,94$ & 24.421 & 0,51 & 0,66 & $11^{\circ}$ \\
\hline Instituto Oceanografico & $1 \%$ & $9.604,47$ & $1 \%$ & $10.239,53$ & 15.699 & 0,61 & 0,65 & $12^{\circ}$ \\
\hline Escola de Educação Fisica & $1 \%$ & $4.692,54$ & $1 \%$ & $5.687,39$ & 10.124 & 0,46 & 0,56 & $13^{\circ}$ \\
\hline Escola Politécnica & - & - & $11 \%$ & $82.798,86$ & 154.190 & - & 0,54 & $14^{\circ}$ \\
\hline Faculdade de Educação & $1 \%$ & $5.767,44$ & $1 \%$ & $7.901,02$ & 22.616 & 0,26 & 0,35 & $15^{\circ}$ \\
\hline Instituto de Psicologia & $1 \%$ & $4.069,32$ & $1 \%$ & $5.002,64$ & 14.706 & 0,28 & 0,34 & $16^{\circ}$ \\
\hline Escola de Comunicação e Artes & $1 \%$ & $6.662,55$ & $1 \%$ & $8.027,45$ & 25.088 & 0,27 & 0,32 & $17^{\circ}$ \\
\hline Prefeitura & $1 \%$ & $7.246,43$ & $1 \%$ & $6.929,01$ & 21.938 & 0,33 & 0,32 & $18^{\circ}$ \\
\hline Faculdade de Arquitetura e Urbanismo & $1 \%$ & $6.100,19$ & $1 \%$ & $7.269,17$ & 24.524 & 0,25 & 0,30 & $19^{\circ}$ \\
\hline Reitoria & $1 \%$ & $9.611,25$ & $1 \%$ & $10.357,26$ & 52.394 & 0,18 & 0,20 & $20^{\circ}$ \\
\hline CUASO & $100 \%$ & $671.296,67$ & $100 \%$ & $732.074,94$ & 848.944 & 0,79 & 0,86 & \\
\hline
\end{tabular}




\section{ANÁLISE DOS RESULTADOS}

A análise preliminar com base na evolução do monitoramento de consumo de energia elétrica na CUASO mostrou que houve um crescimento de aproximadamente $21 \%$ no monitoramento total, passando de 55\% em janeiro de 2005 para $76 \%$ em outubro de 2006. Apesar do grande aumento, a CUASO ainda possui grandes unidades consumidoras sem o acompanhamento do consumo de energia, que pode ser observado nas curvas de carga diária de dias úteis e não úteis.

O perfil atual do monitoramento de consumo da CUASO atinge em sua maioria as unidades com a maior parte do consumo no período compreendido das 08:00 as 21:00 h. Os gráficos das figuras 11 e 12 mostram que o percentual nos dias úteis sofre pequenas variações e nos dias não úteis, o monitoramento aumenta significativamente. Outra característica observada é que os valores percentuais de monitoramento nos horários noturnos, nos dias úteis e não úteis, não sofrem alterações consideráveis, ficando próximo dos 70\%.

Sabendo-se que o sistema de iluminação pública da CUASO possui pouco ou nenhum monitoramento do SISGEN e, analisando os valores totais e de monitoramento na figura 12, é possível estimar, pelo degrau que ocorre entre os horários do amanhecer e anoitecer, o consumo de energia no sistema de iluminação pública. No caso especifico do mês de outubro o degrau foi algo entre 700 e 800 kW médios. 
Outra característica observada é o grande consumo de energia em dias não úteis, que corresponde a um consumo de aproximadamente 53\% comparando-se à média de dias úteis.

A análise conjunta do Hospital Universitário e do Instituto de Ciências Biológicas é necessária, pois parte das instalações do ICB são alimentadas pelos equipamentos do HU. Estas características físicas influem nos resultados dos indicadores globais, específicos e financeiros.

\subsection{Indicadores Globais}

Os indicadores globais foram aplicados às informações de consumo das unidades da CUASO e analisados separadamente levando em consideração as características de cada um dos indicadores.

\subsubsection{Fator de Potência}

Para analisar o fator de potência das unidades utilizaram-se as informações do mês de outubro de 2006, último do período analisado. Das 48 unidades consideradas, apenas 4 delas não apresentaram valores abaixo de 0,92, o mínimo exigido pelo órgão regulador.

A característica de baixo fator de potência na maioria das unidades sobrecarrega os alimentadores de toda a CUASO e, pode acarretar em penalidades por baixo fator de potência. Mesmo com a correção existente próximo ao alimentador no ponto de entrega da concessionária, no mês de outubro, a CUASO apresentou em 
alguns períodos valores abaixo do mínimo exigido, chegando a valores mínimos de até 0,90, que ocasionaram em pagamentos de penalidades.

Os baixos valores verificados na maioria das unidades e na CUASO indicam a necessidade de correção visando evitar posteriores pagamentos de penalidades. Para tanto é necessária uma avaliação dos custos do investimento, confrontando com os valores pagos mensalmente. Outra avaliação essencial é a dos locais para aplicação das correções, que podem ocorrer próximo ao alimentador principal, CUASO, ou próximo dos alimentadores das unidades, como sugere a lista de prioridades de maneira decrescentes de consumo. Observa-se que as maiores unidades, tratando-se de consumo, possuem valores abaixo de 0,92, que se corrigidas poderiam elevar 0 fator de potência global, CUASO, evitando assim o pagamento de penalidades.

\subsubsection{Fator de carga}

Para avaliar as unidades pelo fator de carga utilizou-se do cálculo mensal deste fator em todo o período analisado, em seguida, calculou-se o fator de carga médio e o desvio padrão em dois períodos distintos, letivos e férias escolares.

$\mathrm{Na}$ avaliação da lista de prioridades, observou-se que a grande maioria das unidades possuem fator de carga abaixo de 0,50 , que indica uma característica de baixos fatores de carga na CUASO. No entanto, algumas unidades se destacam pela diferença entre o período letivo e férias escolares, como por exemplo, a unidade "Química Biotério", $1^{\mathrm{a}}$ na lista de prioridades, que apresenta fator médio de 0,47 e desvio de $21 \%$ no período letivo. 
As unidades que possuem fatores acima de 0,50 nos dois períodos possuem baixos desvios e possuem característica diferenciada dentro da CUASO, alguns exemplos são o Hospital Universitário, com atendimento nos períodos noturnos, o Centro de Computação Eletrônica, CCE, que concentra os equipamentos de rede e Internet da CUASO e, os prédios do CRUSP que possuem características residenciais.

O fator de carga pode indicar se existem sazonalidades de demanda ao longo do período verificado, e pode ser utilizado para requisitar condições diferenciadas de faturamento pela caracterização de sazonalidade prevista em ANEELL, 2000. O fator de carga da CUASO é praticamente constante em todos os meses do período, no entanto, não descaracteriza sazonalidade, que pode ser requisitada pelos valores de consumo de energia.

A similaridade dos fatores de carga, destacada na classificação prévia por especialidades, pode auxiliar no dimensionamento de equipamentos em novas instalações com características semelhantes. Observa-se também que os menores fatores de carga e os maiores desvios estão nas unidades de especialidade de ciências exatas.

\subsubsection{Consumo por horários de utilização}

A classificação pelo indicador PCR foi aplicado em dois períodos, sendo das 00:00 as 06:00 $\mathrm{h}$ e das 20:00 as 06:00 h, tendo como referência a média dos consumos de energia de janeiro de 2005 a outubro de 2006. 
A partir da análise dos resultados verificou-se que algumas unidades possuem característica de consumir grande parte da energia nos horários com baixa atividade humana. Pode-se citar como exemplo as 5 (cinco) primeiras unidades da lista de prioridades, que apresentam consumo superior a $20 \%$ do total no intervalo das 00:00 as 06:00 h. Estes valores indicam que existe grande quantidade de equipamentos que permanecem acionados mesmo após a saída de alunos e funcionários.

Verificando as unidades agrupadas por especialidades, nota-se que nas ciências exatas as unidades possuem característica de percentual de consumo maior do que outras especialidades.

\subsection{Indicadores Específicos}

Os indicadores específicos visam identificar o comportamento de uso da energia através das informações e particularidades das unidades consumidoras. A atualização e avaliação periódica auxiliam na verificação de mudanças no comportamento.

\subsubsection{Consumo por usuários da energia}

A avaliação de comportamento no uso da energia elétrica, através dos indicadores de consumo por usuários da energia, necessita de uma avaliação aprofundada das características de utilização das instalações, no que compete à movimentação e tipo de atividade desenvolvida.

Caso não sejam pré-avaliadas as características dos usuários, os resultados do indicador serão prejudicados e pouco auxiliará na gestão e identificação de potenciais 
de economia. A classificação por este indicador aponta o Museu de Artes Contemporâneas, o Centro de Computação Eletrônica e o Hospital Universitário, como as três primeiras unidades como prioridades de atuação dos gestores, no entanto, são instalações que possuem características diferenciadas e, as informações contidas no anuário estatístico não contemplam a totalidade de usuários destas unidades.

Para estes casos é necessário um levantamento do total de visitantes e tipo de exposição que ocorrem no Museu, o número de alunos e professores que utilizam as instalações do CCE e o tempo médio de permanência e, no caso do Hospital Universitário, o número de consultas e pacientes atendidos mensalmente é essencial para que os indicadores mostrem resultados mais coerentes com o comportamento de uso da unidade e seus equipamentos.

Porém, em algumas instalações de mesma especialidade e com semelhanças em suas características de ensino, caso dos Institutos de Geofísica e, Astronomia e Geofísica, possuem resultados muito próximos, indicando comportamentos semelhantes de seus usuários.

As análises a partir dos períodos letivos e férias escolares mostram que na maioria dos casos há uma significativa redução de consumo por usuário, indicando a influência na variação de consumo, no entanto, também nestes casos é necessário um levantamento de permanência e utilização nestes períodos, visando melhores resultados.

Os resultados a partir das especialidades mostram que as ciências exatas possuem unidades com boa proximidade e outros casos com diferenças significativas, 
que não permitem grandes conclusões. O mesmo ocorre em outras especialidades, como nas ciências humanas, embora possua resultados mais próximos, mas com diferenças significativas, atingindo valores superiores a $50 \%$.

\subsubsection{Consumo por Área edificada}

A avaliação dos resultados de classificação das unidades pelo indicador por área edificada aponta novamente o Centro de Computação Eletrônica, o Hospital Universitário e o Museu de Artes Contemporâneas como as três primeiras unidades como prioridades de atuação dos gestores. Analogamente ao indicador de usuários da energia é necessário o levantamento mais aprofundado das particularidades das unidades, para obter melhores resultados do indicador.

No entanto, os resultados das demais unidades mostram-se mais próximos, sobretudo se tratando das especialidades. Esta característica aponta semelhanças no comportamento de uso da energia elétrica, no que diz respeito às informações físicas.

Analisando os resultados nos períodos letivos e férias escolares, verificou-se que na maior parte das unidades o consumo por área edificada diminui nos períodos de férias, indicando que a redução de atividades influencia diretamente na redução do consumo de energia elétrica.

\subsubsection{Consumo por uso final - Sistemas de refrigeração e ar condicionado}

A classificação por indicador de uso final em sistemas de ar condicionado e refrigeração não atinge todas as utilizações destes sistemas nas instalações, no 
entanto, faz um comparativo do aumento de consumo de energia elétrica, a partir do aumento de temperatura ambiente.

Utilizando-se das informações de três meses com características diferenciadas é possível identificar quais os períodos que sofrem maior influência da temperatura, em relação ao consumo de energia.

A análise dos resultados em termos percentuais do consumo total das unidades, para temperaturas acima dos $22^{\circ} \mathrm{C}$, destaca a Faculdade de Economia e Administração, com valores superiores a 30\% total, no mês de março de 2005.

Vinculando as informações de consumo estimado, a partir da temperatura considerada, aos indicadores por usuários e área edificada, destacaram-se novamente o Museu de Artes Contemporâneas, o Centro de Computação Eletrônica e o Hospital Universitário, além das Faculdades de Economia e Administração e Ciências Farmacêuticas.

No caso específico das Faculdades de Economia e Administração e Ciências Farmacêuticas, os resultados do indicador de área edificada apontaram um aumento no consumo por área edificada no mês de Março de 2005, de aproximadamente 43\% e 22\%, respectivamente. Este resultado é a comparação do resultado do período letivo na tabela 14, com o obtido na estimativa apresentada na tabela 16. 


\subsubsection{Consumo por uso final - Sistemas de iluminação}

A avaliação do consumo de energia por uso final em sistema de iluminação foi prejudicada pela falta de uma estimativa de consumo neste tipo de sistema, nas unidades consideradas no estudo.

No entanto, para exemplificar a aplicação do indicador, utilizaram-se as informações do diagnóstico para substituição de equipamentos de iluminação no Instituto de Psicologia (PUREFA, 2006).

O resultado mostrou um consumo estimado em sistemas de iluminação de aproximadamente $13 \%$ do total da unidade e, aplicaram-se os indicadores financeiros para verificar a participação nos custos da unidade.

\subsubsection{Consumo por uso final - Equipamentos de informática}

A classificação por consumo de energia em uso final de equipamentos de informática considerou apenas os microcomputadores contidos no anuário estatístico da USP. A estimativa de consumo considerou uma potencia média dos equipamentos de 110 W e um período de utilização diária de 8 horas.

Associaram-se ao resultado da estimativa de consumo o número de usuários de cada unidade para realizar a classificação em número de máquinas por usuário e consumo de energia em equipamentos de informática por usuário.

O resultado aponta o Centro de Computação Eletrônica como o maior consumidor de energia por usuário neste uso final e, novamente é necessária uma 
avaliação mais apurada do número de alunos e professores que utilizam as instalações do CCE e o tempo médio de permanência, para obter melhores resultados.

A análise dos resultados nas diferentes especialidades mostra que as ciências exatas possuem índices superiores às demais, nas quais se pode verificar uma maior similaridade, tanto na quantidade de máquinas por usuário quanto no consumo de energia.

\subsubsection{Custos com energia elétrica}

Para classificar as unidades pela participação nos custos totais com energia elétrica aplicaram-se ao consumo mensal, os preços de energia da concessionária que atende a CUASO. Após obter os custos mensais com energia elétrica na CUASO, utilizou-se a média dos períodos letivos e férias escolares, para verificar o percentual de consumo das unidades e obter a participação individual nos custos totais.

Aos resultados foram aplicados os indicadores por usuário e área edificada e, novamente destacaram-se o Museu de Artes Contemporâneas, o Centro de Computação Eletrônica e o Hospital Universitário como prioridades de atuação dos gestores.

Outra comparação foi realizada no intuito de estimar a redução de custos, caso a CUASO operasse no Ambiente de Contratação Livre, ACL. Esta análise exemplifica possíveis reduções de custos com a possibilidade de negociação bilateral de preços de energia diretamente com o fornecedor. 
Os preços utilizados na comparação são uma média anual do PLD da CCEE, que aliado ao Custo Marginal de Operação ${ }^{14}$ para os próximos anos, serve de base para as negociações entre os agentes do mercado livre de energia. Atualmente os preços do mercado livre encontram-se muito próximos dos preços do ambiente cativo, ou seja, as reduções de custos com a migração para o ambiente livre são de proporções menores.

Admitindo-se que a CUASO possuía contratos de longo prazo baseados na média anual do Preço de Liquidação das Diferenças, o PLD, a economia estimada no período foi de aproximadamente $\mathrm{R} \$ 4$ milhões $^{15}$.

${ }^{14}$ CMO - Custo Marginal de Operação: Produto da ferramenta de otimização do despacho energético, o NEWAVE, utilizada pelo Operador Nacional do Sistema, o ONS.

${ }^{15} \mathrm{Não}$ foram considerados as atualizações financeiras e os impostos. 


\section{CONCLUSÕES E DESENVOLVIMENTOS FUTUROS}

Da analise do perfil de monitoramento de consumo de energia elétrica da CUASO constatou-se que grande parte do consumo nos horários noturnos ainda não possui acompanhamento pela ferramenta de gestão da USP, o SISGEN. O mesmo ocorre nos dias úteis, nos horários diurnos, indicando que várias unidades necessitam da instalação para que seja possível a avaliação do comportamento de consumo através dos indicadores.

Nos dias não úteis é possível constatar que o monitoramento nos horários diurnos aumenta significativamente, demonstrando que as unidades ainda não monitoradas têm pouca atividade nestes períodos. É possível também estimar o consumo nos sistemas de iluminação pública, a partir dos degraus na curva de carga média de dias não úteis. Esta estimativa é possível, pois se sabe que a alimentação dos sistemas de iluminação pública é separada das demais unidades e possui pouco espaço físico para a instalação do SISGEN. Os valores estimados a partir das análises do gráfico da figura 12 são de consumo médio por hora da ordem de 700 a 800 kWh.

O alto consumo de energia elétrica em dias não úteis é outra característica identificada a partir das análises do perfil de monitoramento, pois na comparação com dias úteis no mês de outubro de 2006, verificou valores de $53 \%$.

A classificação pelo fator de potência das unidades não possui relação com o tipo de atividade desenvolvida ou especialidade de ensino. A correção dos valores evitará penalidades futuras, no entanto, é necessária uma avaliação mais aprofundada para avaliar os locais para instalação dos equipamentos de correção, os custos iniciais 
e a estimativa de retorno do investimento. Da lista de prioridades identificou-se que as unidades de maior consumo na CUASO, possuem valores bem abaixo do mínimo especificado pelo órgão regulador e, a correção de algumas destas unidades poderá elevar o fator de potencia global evitando novas penalidades.

A classificação pelo fator de carga mostrou que a grande maioria das unidades possui um baixo fator de carga e, conseqüente, a CUASO registra valores da ordem de 0,50. Constatou-se que há uma variação significativa ao longo do período analisado, sendo assim, uma avaliação aprofundada dos valores de consumo e demanda em todo o período pode identificar características de sazonalidade. Prevista no artigo n 63 da resolução no 456 da ANEEL (ANEEL, 2000), a sazonalidade, se caracterizada na instalação, possibilita a celebração de contratos diferenciados com a concessionária.

Em caso de novas instalações o fator de carga poderá ser utilizado para estimar o consumo e demanda, auxiliando assim no dimensionamento dos equipamentos de alimentação.

O indicador PCR identifica grandes consumos de energia nos horários noturnos na maioria das unidades consideradas e, destaca as ciências exatas como a especialidade que possui os maiores consumos. As ações dos gestores de acordo com a lista de prioridades deste indicador deverão ter como base as orientações e conscientização visando mudanças de comportamento no uso da energia elétrica, e assim, reduzir o consumo nos períodos noturnos. 
Os resultados do indicador de consumo por usuários da energia são pouco conclusivos, no que diz respeito a identificar similaridades no uso da energia. Para obter melhores resultados é necessária uma avaliação prévia do comportamento dos usuários e qual o tempo de permanência nas instalações.

Exceto por algumas unidades, como no caso dos Institutos de Geofísica e, Astronomia e Geofísica, que mostraram resultados próximos e são de especialidades de ensino semelhantes, os valores se mostraram com grandes diferenças e pouco auxiliarão os gestores na priorização das ações.

Diferentemente, o indicador por área edificada identificou proximidade dos valores obtidos nas unidades e dentro das especialidades, ou seja, com a identificação das unidades mais eficientes do ponto de vista de comportamento e equipamentos com tecnologias mais econômicas, é possível realizar uma comparação com outras instalações semelhantes e identificar os potenciais de redução de consumo.

Os indicadores por usos finais exigem uma estimativa de consumo de energia e, nos casos de aplicação em sistemas de refrigeração e ar condicionado, a estimativa adotada não contempla todas as utilizações deste tipo de uso final, pois a temperatura ambiente é apenas uma das variáveis que influenciam na variação de consumo e utilização destes sistemas.

No entanto, a metodologia para estimar o consumo a partir de uma determinada temperatura, faz uma ligação entre o aumento de consumo e as condições do ambiente, ou seja, algumas instalações são mais sensíveis à variação de temperatura, como foi detectado na lista de prioridades. 
O levantamento dos tipos de equipamento utilizado, tecnologia e eficiência poderão identificar grandes potenciais de redução de consumo com a substituição dos equipamentos. A avaliação das condições do ambiente em que são utilizados estes usos finais poderá reduzir o consumo de energia elétrica, com ações simples de conscientização e mudanças no comportamento dos usuários.

No caso específico do uso final em sistemas de iluminação não foi possível realizar a classificação por prioridades das unidades, pois a estimativa de consumo exigiria um levantamento da quantidade de equipamentos, potência nominal e horários de utilização. No entanto, para demonstrar a aplicação do indicador utilizaram-se as informações do Instituto de Psicologia e, o resultado mostrou um consumo com iluminação de aproximadamente $13 \%$ do total da unidade.

Com apenas os resultados do Instituto de Psicologia, não é possível obter nenhum resultado conclusivo do tipo de identificação de semelhanças no comportamento do uso e potenciais de redução nas demais unidades.

O indicador por uso final em equipamentos de informática mostrou resultados que indicam um consumo significativo neste uso final e destaca as ciências exatas como a especialidade com os maiores índices.

Em algumas unidades a quantidade de micro computadores é superior ao numero de usuários totais e em outras o índice de equipamentos por usuário é menor que $10 \%$, ou seja, um equipamento para cada 10 usuários. Tratando-se de consumo de energia, as especialidades apontam semelhanças em algumas unidades e grandes diferenças em outras, ou seja, os resultados são pouco conclusivos. 
A avaliação de aumento ou diminuição da quantidade de equipamentos nas unidades deve ser realizada no intuito de promover a equalização da oportunidade de acesso à informática por alunos, professores e outros funcionários.

Com o auxílio dos indicadores financeiros foi possível verificar a participação das unidades nos custos totais com energia elétrica e identificar qual a participação de cada usuário final nos custos mensais, bem como os custos por $\mathrm{m}^{2}$ de área edificada.

A comparação com o ambiente de contratação livre apontou inicialmente uma grande economia de recursos e, sendo assim, deve-se realizar um estudo para verificar a viabilidade de aderir a este ambiente.

Os indicadores financeiros podem ser associados a qualquer um dos indicadores específicos e ao indicador global PCR, no intuito de identificar os custos por usos finais, horários de utilização, área e usuários.

A criação de uma metodologia de rateio de custos com energia, entre todas as unidades, auxiliará no aumento do comprometimento dos usuários com a eficiência energética e o uso consciente da energia elétrica, pois ao estabelecer um teto, ou metas de resultado aos responsáveis das unidades, a exigência aos usuários partirá de pessoas mais próximas e com maior ênfase. Para tornar possível este rateio é necessário que o monitoramento do consumo de energia elétrica seja total ou atinja a grande maioria das unidades da CUASO.

Baseando-se nas listas de prioridades de todos os indicadores, foi possível identificar as unidades com maior incidência, para isso, as cinco primeiras unidades de 
cada uma das listas foram relacionadas, criando a lista de prioridades final geral e por especialidades, nas tabelas 25 e 26.

TABELA 25: LISTA DE PRIORIDADES FINAL - INCIDÊNCIA DE INDICADORES

\begin{tabular}{|l|c|}
\hline \multicolumn{1}{|c|}{ Unidades } & $\begin{array}{c}\text { Incidência de } \\
\text { Indicadores }\end{array}$ \\
\hline Hospital Universitario/ICB & 9 \\
\hline Centro de Computação Eletronica & 8 \\
\hline Museu de Arte Contemporânea & 7 \\
\hline Instituto de Geociência & 4 \\
\hline Instituto de Química & 4 \\
\hline Faculdade de Ciencias Farmacêuticas & 3 \\
\hline Faculdade de Economia e Administração & 3 \\
\hline Instituto de Matemática e Estatística & 3 \\
\hline Instituto de Astronomia e Geociência & 2 \\
\hline Instituto de Energia e Eletrotécnica & 2 \\
\hline Instituto Oceanografico & 2 \\
\hline Escola de Comunicação e Artes & 1 \\
\hline Escola Politécnica & 1 \\
\hline Faculdade de Educação & 1 \\
\hline Faculdade de Odontologia & 1 \\
\hline Instituto de Física & 1 \\
\hline Prefeitura & 1 \\
\hline Reitoria & 1 \\
\hline
\end{tabular}

TABELA 26: Lista de PRIORIDAdES FinAL - INCIDÊNCIA DE INDICADORES POR ESPECIALIDADE

\begin{tabular}{|c|c|c|}
\hline & Unidades & $\begin{array}{c}\text { Incidência de } \\
\text { Indicadores }\end{array}$ \\
\hline \multirow{2}{*}{ Saúde } & Hospital Universitario/ICB & 9 \\
\hline & Faculdade de Ciencias Farmacêuticas & 3 \\
\hline Lazer e Cultura & Museu de Arte Contemporânea & 7 \\
\hline \multirow{4}{*}{ Humanas } & Faculdade de Economia e Administração & 3 \\
\hline & Escola de Comunicação e Artes & 1 \\
\hline & Faculdade de Educação & 1 \\
\hline & Faculdade de Odontologia & 1 \\
\hline \multirow{8}{*}{ Exatas } & Centro de Computação Eletronica & 8 \\
\hline & Instituto de Geociência & 4 \\
\hline & Instituto de Química & 4 \\
\hline & Instituto de Matemática e Estatística & 3 \\
\hline & Instituto de Astronomia e Geociência & 2 \\
\hline & Instituto de Energia e Eletrotécnica & 2 \\
\hline & Escola Politécnica & 1 \\
\hline & Instituto de Física & 1 \\
\hline Biológicas & Instituto Oceanografico & 2 \\
\hline \multirow{2}{*}{ Administrativa } & Prefeitura & 1 \\
\hline & Reitoria & 1 \\
\hline
\end{tabular}

Observa-se que o Hospital Universitário, o Centro de Computação Eletrônica e o Museu de Artes Contemporâneas são as unidades com maior incidência, no entanto, 
necessitam de uma avaliação mais apurada em todos os indicadores, visando obter melhores resultados. As ciências exatas possuem o maior número de unidade e com as maiores incidências.

Esta lista final de prioridades deverá ser utilizada pelos gestores para que as ações de eficiência energética e gestão de recursos sejam focadas nas unidades com os maiores potenciais de redução.

\subsection{Sugestão para desenvolvimentos futuros}

A sugestão para desenvolvimentos futuros é para o desenvolvimento de metodologias para desagregar o consumo em usos finais sem a necessidade de levantamentos de quantidade e potência nominal dos equipamentos, através do estudo das curvas de carga típica dos usos finais mais utilizados associado à curva de carga global das unidades.

O desenvolvimento deste tipo de metodologia contribuirá para a utilização e atualização dos indicadores de consumo de energia elétrica e acompanhar a evolução no comportamento do uso. 


\section{REFERÊNCIAS BIBLIOGRÁFICAS}

[1] ABNT. Associação Brasileira de Normas Técnicas. I luminância de I nteriores. Especificações. NBR 5413. Rio de Janeiro: ABNT, 1992.

[2] AEBISCHER, B.; BALMER, M. A.; KINNEY, S.; LE STRAT, P.; SHIBATA, Y.; VARONE F. Energy Efficiency Indicators for High Electric-Load Buildings. In: HPCBS (High Performance Commercial Building Systems). Raphael. França, 2003.

[3] ALVAREZ, A.L.M. Uso racional e eficiente de energia elétrica: Metodologia para a determinação dos potenciais de conservação dos usos finais em instalações de ensino e similares. 1998. 159p. Dissertação (Mestrado) - Escola Politécnica, Universidade de São Paulo. São Paulo, 1998.

[4] ANEEL. Agência Nacional de Energia Elétrica. Condições Gerais de Fornecimento de Energia Elétrica. Resolução 456/2000. Brasília: ANEEL, 2000.

[5] ANEEL/ANP. Eficiência Energética: Integrando Usos e Reduzindo Desperdícios. Brasília, 1999.

[6] ATTHAJARIYAKUL, S.; LEEPHAKPREEDA, T. Real-time determination of optimal indoor-air condition for thermal comfort, air quality and efficient energy usage. School of Industrial and Mechanical Engineering, Sirindhorn International Institute of Technology, Thammasat University, Thailand. In: Energy and Buildings 36, 2004. 
[7] BEN-NAKHI, A. E., MAHMOUD, M. A. Cooling load prediction for buildings using general regression neural networks. Department of Mechanical Engineering, College of Technology, Kuwait. In: Energy Conversion and Management 45. 2004.

[8] ELETROBRÁS/PROCEL. Conservação de Energia: Eficiência Energética de Instalações e Equipamentos. I tajubá: EE, 2001.

[9] FARINHA, C.; FERREIRA, J.J.; ALVES, D. A Utilização Racional de energia no âmbito das pequenas e médias empresas. Lisboa. Portugal, 1988.

[10] FERREIRA, J. J.; FERREIRA; T. J. Economia e Gestão da Energia. Lisboa: Texto, 1994. 156p.

[11] FERREIRA, J. J. Indicadores de Eficiência Energética (Portugal): Projeto SAVE/EnR "Cross Country Comparison on Energy Efficiency Indicators", Junho/1995 64p.

[12] GOldemberg, J.; VILlanUeVA, L. D. Energia, Meio Ambiente \& Desenvolvimento. São Paulo, Brasil: Edusp, 2003.

[13] INSTITUTE OF ENERGY ECONOMICS. Energy Efficiency Indicators: A Study Of Energy Efficiency I ndicators For I ndustry In Apec Economies. Tokyo. Japan. Asia Pacific Energy Research Center, 2000.

[14] IWASHITA, J.. Eficiência energética em sistemas de iluminação de interiores: análise de luminárias comerciais. 2004 120p. Dissertação (Mestrado) - Escola Politécnica da Universidade de São Paulo. São Paulo, 2004. 
[15] LaAR. Laboratorio de Ar-condicionado e Refrigeração. Universidade de Brasília. Faculdade de Tecnologia Departamento de Engenharia Mecânica. http://www.laar.unb.br/saibamais_compressores.htm - Acesso 05/2006.

[16] LEE, A. S.; WESTPHAL, F. S.; LAMBERTS, R. Verificação da Eficiência Energética de um Edifício de Escritórios Através de Simulação Computacional: Estudo de Caso no Departamento de Engenharia Civil da UFSC. In: VI Encontro Nacional e III Encontro Latino-Americano sobre Conforto no Ambiente Construído. São Pedro, 2001.

[17] PROCEL. Programa nacional de Conservação de Energia Elétrica: Sistemas de Ar Condicionado e Refrigeração - J ulho, 2002.

[18] PROCEL. Programa nacional de Conservação de Energia Elétrica. Web site: http://www.eletrobras.gov.br/procel - Acesso: 04/2006.

[19] SANTOS Jr., C. M.; SAIDEL, M. A.; HENRIQUES, M. S. S. C. Economia de Energia em Ambientes de Escritório através do Gerenciamento de Microcomputadores. XVI SEMINÁRIO NACIONAL DE DISTRIBUIÇÃO DE ENERGIA ELÉTRICA. SENDI 2004. Brasília, Brasil, 2004.

[20] SAIDEL, M. A.; GIMENES, A. L. V.; ROSA, L.H.L. Requisitos de um Sistema de Informação Autônomo para Suporte à Gestão de Energia. In: Transmission and Distribution - IEEE/PES T\&D Latin America. 2004. São Paulo, SP, 2004.

[21] SAIDEL, M.A. A Gestão de Energia Elétrica na USP: O Programa Permanente para o Uso Eficiente de Energia Elétrica. 2005. 166p. Tese 
(Livre Docência) - Escola Politécnica, Universidade de São Paulo. São Paulo, 2005.

[22] SAIDEL, M. A.; FAVATO, L. B.; MORALES, C. Indicadores Energéticos e Ambientais: Ferramenta I mportante na Gestão da Energia Elétrica. Departamento de Engenharia de Energia e Automação Elétricas da Escola Politécnica da Universidade de São Paulo. In: Congresso Brasileiro de Eficiência Energética - CBEE/ABEE. Belo Horizonte, 2005.

[23] SAIDEL, M. A.; GIMENES, A. L. V.; MORALES, C.; LADEIRA, R. Ferramenta Computacional para Previsão de Curva de Carga a partir da Previsão de Temperatura Ambiente. In: Internacional Congress on Electricity Distribution. CIDEL. Buenos Aires. Argentina, 2006.

[24] SCHIPPER, L.; UNANDER, F.; MURTISHAW, S.; TING, M. Indicators of Energy Use And Carbon Emissions: Explaining The Energy Economy Link. Annu. Rev. Energy. Environ. USA, 2001. 38p.

[25] UYTERLINDE, M. A.; VAN ARKEL, W.G.; BURGER, H.; VAN DRIL, A.W.N.; JEENINGA, H.; KROON, P. Monitoring Energy Efficiency I ndicators in The Netherlands in 1999: Dutch contribution to the project 'Cross country comparison on energy efficiency - Phase 5. Netherlands, 2000 . 74p.

[26] USP. Universidade de São Paulo. Anuário estatístico - 2005. São Paulo, 2006.

[27] WESTPHAL, F. S.; LAMBERTS, R. A Methodology To Analyse The Thermal Loads Of Nonresidential Buildings Based On Simplified Weather Data. 
Energy Efficiency in Buildings Laboratory. Federal University of Santa Catarina. In: Eighth International IBPSA Conference. Eindhoven, Netherlands, 2003.

[28] WORLD ENERGY COUNCIL. Energy Efficiency Policies and Indicators: A Report by the World Energy Council. London. United Kingdom, 2001.

[29] FAVATO, L. B. Indicadores de Eficiência Energética em Edifícios da USP: Concepção, Aplicabilidade e Desdobramentos Energético - Ambientais Associados. 2005. 46p. Dissertação (Mestrado). Instituto de Pesquisas Tecnológicas do Estado de São Paulo - IPT. São Paulo, 2005.

[30] PUREFA. Diagnostico para substituição de equipamentos de iluminação no Instituto de Psicologia da USP. Projeto Purefa - São Paulo, 2006.

[31] MINAKI, C; AMORIM, M. C. C. T. Características de temperatura e conforto térmico em ambiente urbano e rural: Episódios de Verão. 2004. UNESP - Campus Presidente Prudente.

[32] AGUAS, M. P. N. Conforto Térmico - Disciplina de Mestrado: Métodos Instrumentais em Energia e Ambiente. 2001. 25p. Instituto Superior Técnico - IST. Universidade de Lisboa. Lisboa, Portugal, 2001.

[33] ANEEL. Agência Nacional de Energia Elétrica. Tarifas de Fornecimento de Energia Elétrica - Eletropaulo Metropolitana Eletricidade de São Paulo. Resolução 165/2004. Brasília: ANEEL, 2004.

[34] ANEEL. Agência Nacional de Energia Elétrica. Tarifas de Fornecimento de Energia Elétrica - Eletropaulo Metropolitana Eletricidade de São Paulo. Resolução 147/2005. Brasília: ANEEL, 2005. 
[35] ANEEL. Agência Nacional de Energia Elétrica. Tarifas de Fornecimento de Energia Elétrica - Eletropaulo Metropolitana Eletricidade de São Paulo. Resolução 356/2006. Brasília: ANEEL, 2006.

[36] Rosa, L. H. L. Sistema de apoio à gestão de utilidades e energia: aplicação de conceitos de sistemas de informação e de apoio à tomada de decisão - dissertação de Mestrado - Escola Politécnica, Universidade de São Paulo. São Paulo, 2007.

[37] CCEE. Câmara de Comercialização de Energia Elétrica. Web site: http://www.ccee.org.br - Acesso: 02/2007. 